НОВАЯ НАУКА Международный центр научного партнерства
NEW SCIENCE

International Center for Scientific Partnership

\title{
АКТУАЛЬНЫЕ ВОПРОСЫ И ВЕКТОРЫ РАЗВИТИЯ СОВРЕМЕННОЙ ФИЛОЛОГИИ
}

Монография

г. Петрозаводск

МЦНП «Новая наука»

2021 


\section{УДК 8}

ББК 80

A43

Рекомендовано к публикаџии редакиионной коллегией МЦНП «Новая наука»

\section{Рецензенты :}

Гапоненко И. О.

доктор филологических наук, профессор

Белорусский государственный университет

Зверева Т. В.

доктор филологических наук, профессор

ФГБОУ ВО «Удмуртский государственный университет»

\section{Коллектив авторов:}

Будаева Л.Н., Карамов Т.Д., Карамова А.А., Конникова В.Н., Потехина Е.С., Руденко Е.Е., Фесюкова И., Хайруллина А.С. ФИЛОЛОГИИ : монография / [Будаева Л. Н. и др.]. - Петрозаводск : МЦНП «Новая наука», 2021. - 144 с. : ил. - Коллектив авторов.

\section{ISBN 978-5-00174-315-6}

В монографии рассматривается круг актуальных вопросов, стоящих перед современными филологами в обозначенных областях, предлагается новое видение ряда концептов. Издание может быть полезно филологам, научным работникам, специалистам-практикам, преподавателям всех уровней образования, интересующимся проблемами развития современной филологии.

Авторы публикуемых статей несут ответственность за содержание своих работ, точность цитат, легитимность использования иллюстраций, приведенных цифр, фактов, названий, персональных данных и иной информации, а также за соблюдение законодательства Российской Федерации и сам факт публикации.

Полные тексты статей в открытом доступе размещены в Научной электронной библиотеке Elibrary.ru в соответствии с Договором № 467-03/2018K от 19.03.2018 г.

УДК 8

ББК 80

ISBN 978-5-00174-315-6 


\section{ОГЛАВЛЕНИЕ}

ГЛАВА І. ЛИНГВИСТИЧЕКАЯ ЭКСПЕРТИЗА РЕЧЕВЫХ АКТОВ ОСКОРБЛЕНИЯ (ПО РАЗНЫМ КАТЕГОРИЯМ ДЕЛ) 4

Карамова Айгуль Айратовна, Карамов Тимур Дмитриевич

ГЛАВА ІІ. ТЕХНОЛОГИЯ ОБУЧЕНИЯ ПИСЬМУ И НАПИСАНИЮ РАЗЛИЧНЫХ ВИДОВ ПИСЬМЕННЫХ ПОСЛАНИЙ НА УРОКАХ РУССКОГО ЯЗЫКА КАК ИНОСТРАННОГО 42

Будаева Людмила Николаевна

ГЛАВА ІІІ. РОЛЬ ЭВФЕМИЗМА В СОВРЕМЕННОМ МИРЕ .58

Руденко Елена Евгеньевна, Потехина Евгения Семеновна

ГЛАВА IV. АКТУАЛЬНЫЕ ПРОБЛЕМЫ НЕПЕРЕВОДИМОСТИ .76

Фесюкова Ирена

ГЛАВА У. ПРОЗА Р. ВАЛЕЕВА В КОНТЕКСТЕ

ТАТАРСКОЙ ЛИТЕРАТУРЫ ВТОРОЙ ПОЛОВИНЫ ХХ ВЕКА 108

Хайруллина Альфира Салихзяновна

ГЛАВА VІ. ОСОБЕННОСТИ ИСПОЛЬЗОВАНИЯ ЛИТЕРАТУРНЫХ ЭЛЕМЕНТОВ В КИБЕРТЕКСТАХ: ПРИСПОСОБЛЕНИЕ ЛИТЕРАТУРЫ К ИНТЕРАКТИВНОЙ СРЕДЕ.

Конникова Виктория Николаевна 


\title{
ГЛАВА І.
}

\section{УДК 81'44}

\section{ЛИНГВИСТИЧЕКАЯ ЭКСПЕРТИЗА}

РЕЧЕВЫХ АКТОВ ОСКОРБЛЕНИЯ (ПО РАЗНЫМ КАТЕГОРИЯМ ДЕЛ)

Карамова Айгуль Айратовна

д.ф.н., профессор кафедры филологии

Бирский филиал БашГУ

Карамов Тимур Дмитриевич

Уфимский юридический институт МВД России

Аннотация: Цель исследования - обобщение имеющегося теоретического и практического опыта в области лингвистической экспертизы спорных текстов по делам об оскорблении, выработка решений по усовершенствованию методики проведения экспертизы. В ходе исследования затрагиваются юридический и лингвистический аспекты проблемы.

Ключевые слова: лингвистическая экспертиза, оскорбление, речевой акт, речевой жанр, оценка, неприличная форма выражения.

\section{LINGUISTIC EXAMINATION OF VERBAL ACTS OF INSULT (FOR DIFFERENT CATEGORIES OF CASES)}

\section{Karamova Aigul Airatovna Karamov Timur Dmitrievich}

\begin{abstract}
The purpose of the study is to generalize the existing theoretical and practical experience in the field of linguistic expertise of controversial texts in cases of insult, to develop solutions for improving the methodology of examination. In the
\end{abstract}


course of the research, the legal and linguistic aspects of the problem are touched upon.

Key words: Linguistic expertise, insult, speech act, speech genre, assessment, indecent form of expression.

Актуальность обращения к данной теме обусловлена следующими фактами.

Демократизация языка, наблюдающаяся в конце XX - начале XXI вв., часто приводит к речевой вседозволенности. «... наш язык сегодня используется как инструмент сознательных (а потому особенно позорных) и неосознанных нарушений этических норм и традиций, правовых норм, закрепленных статьями соответствующих кодексов РФ» $[1$, с. 5]. Заметное место среди таких правонарушений занимает оскорбление. Более того, оскорбление, по мнению исследователей, является одним из центральных концептов юридической лингвистики [2, с. 73$]$.

При исследовании спорных текстов по делам об оскорблении лингвист сталкивается с рядом проблемных вопросов: понятие и границы инвективы, понятие неприличной формы выражения, понятия из области филологической теории коммуникации, понятия лингвоконфликтологии: речевая агрессия, речевой конфликт. Решение данных и многих других вопросов значительно облегчит практику лингвистических исследований спорных текстов.

«Очевидно, что понятие оскорбления не имеет объективных критериев, четких диагностических признаков», - отмечает И.А. Стернин [3, с. 27]. Поэтому разработка критериев, четких диагностических признаков - еще одна важная задача, которая требует решения.

Цель исследования - обобщение имеющегося теоретического и практического опыта в области лингвистической экспертизы спорных текстах по делам об оскорблении, выработка решений по усовершенствованию методики исследования. 


\section{1 Оскорбление как юридическое понятие. Диагностические признаки оскорбления как юридического понятия}

Оскорбление как правонарушение входит в содержание следующих категорий дел [4].

I. Кодекс Российской Федерации об административных правонарушениях от 30.12.2001 N 195-Ф3 (ред. от 09.03.2021) (с изм. и доп., вступ. в силу с 27.03.2021). Статья 5.61. Оскорбление.

Часть. 1. Оскорбление, то есть унижение чести и достоинства другого лица, выраженное в неприличной или иной противоречащей общепринятым нормам морали и нравственности форме.

Часть. 2. Оскорбление, содержащееся в публичном выступлении, публично демонстрирующемся произведении или средствах массовой информации либо совершенное публично с использованием информационно-телекоммуникационных сетей, включая сеть "Интернет", или в отношении нескольких лиц, в том числе индивидуально не определенных.

Часть. 4. Оскорбление, совершенное лицом, замещающим государственную или муниципальную должность либо должность государственной гражданской или муниципальной службы, в связи с осуществлением своих полномочий (должностных обязанностей).

II. Уголовный кодекс Российской Федерации от 13.06.1996 N 63-Ф3 (ред. от 05.04.2021, с изм. от 08.04.2021):

Статья 319. Оскорбление представителя власти: публичное оскорбление представителя власти при исполнении им своих должностных обязанностей или в связи с их исполнением (в ред. Федеральных законов от 08.12.2003 N 162-ФЗ, от $07.03 .2011 \quad \mathrm{~N} \quad 26-\Phi 3, \quad$ от $07.12 .2011 \quad \mathrm{~N} \quad 420-\Phi 3)$. 
Статья 297. Неуважение к суду:

Часть 1. Неуважение к суду, выразившееся в оскорблении участников судебного разбирательства (в ред. Федеральных законов от 08.12.2003 N 162-Ф3, от 07.03.2011 N 26-Ф3, от 07.12.2011 N 420-Ф3).

Часть 2. То же деяние, выразившееся в оскорблении судьи, присяжного заседателя или иного лица, участвующего в отправлении правосудия (в ред. Федеральных законов от 08.12.2003 N 162-Ф3, от 06.05.2010 N 81-Ф3, от 07.03.2011 N 26-Ф3, от 07.12.2011 N 420-Ф3).

Статья 336. Оскорбление военнослужащего:

Часть 1. Оскорбление одним военнослужащим другого во время исполнения или в связи с исполнением обязанностей военной службы.

Часть 2. Оскорбление подчиненным начальника, а равно начальником подчиненного во время исполнения или в связи с исполнением обязанностей военной службы.

Статья 107. Убийство, совершенное в состоянии аффекта:

Часть 1. Убийство, совершенное в состоянии внезапно возникшего сильного душевного волнения (аффекта), вызванного насилием, издевательством или тяжким оскорблением со стороны потерпевшего либо иными противоправными или аморальными действиями (бездействием) потерпевшего, а равно длительной психотравмирующей ситуацией, возникшей в связи с систематическим противоправным или аморальным поведением потерпевшего (в ред. Федерального закона от 07.12.2011 N 420-Ф3).

Часть 2. Убийство двух или более лиц, совершенное в состоянии аффекта (в ред. Федерального закона от 07.12.2011 N 420-Ф3).

Статья 113. Причинение тяжкого или средней тяжести вреда здоровью в состоянии аффекта: Умышленное причинение тяжкого или средней тяжести вреда здоровью, совершенное в состоянии внезапно возникшего сильного душевного волнения (аффекта), вызванного насилием, издевательством или тяжким оскорблением со стороны потерпевшего либо иными противоправными 
или аморальными действиями (бездействием) потерпевшего, а равно длительной психотравмирующей ситуацией, возникшей в связи с систематическим противоправным или аморальным поведением потерпевшего (в ред. Федерального закона от 07.12.2011 N 420-Ф3).

III. Уголовно-исполнительный кодекс Российской Федерации от 08.01.1997 N 1-Ф3 (ред. от 05.04.2021):

Статья 116. Злостное нарушение установленного порядка отбывания наказания осужденными к лишению свободы:

Часть 1. Злостным нарушением осужденными к лишению свободы установленного порядка отбывания наказания являются: употребление спиртных напитков либо наркотических средств или психотропных веществ; мелкое хулиганство; угроза, неповиновение представителям администрации исправительного учреждения или их оскорбление при отсутствии признаков преступления; изготовление, хранение или передача запрещенных предметов; уклонение от исполнения принудительных мер медицинского характера или от обязательного лечения, назначенного судом или решением медицинской комиссии; организация забастовок или иных групповых неповиновений, а равно активное участие в них; мужеложство, лесбиянство; организация группировок осужденных, направленных на совершение указанных в настоящей статье правонарушений, а равно активное участие в них; отказ от работы или прекращение работы без уважительных причин (часть первая в ред. Федерального закона от 09.03.2001 N 25-Ф3).

IV. Семейный кодекс Российской Федерации от 29.12.1995 N 223-Ф3 (ред. от 04.02.2021, с изм. от 02.03.2021):

Статья 65. Осуществление родительских прав:

Часть 1. Родительские права не могут осуществляться в противоречии с интересами детей. Обеспечение интересов детей должно быть предметом основной заботы их родителей. При осуществлении родительских прав родители не вправе причинять вред физическому и психическому здоровью 
детей, их нравственному развитию. Способы воспитания детей должны исключать пренебрежительное, жестокое, грубое, унижающее человеческое достоинство обращение, оскорбление или эксплуатацию детей.

V. Трудовой кодекс Российской Федерации от 30.12.2001 № 197Ф3 (в ред. от 05.04.2021):

Статья 336. Дополнительные основания прекращения трудового договора с педагогическим работником, а также руководителем, заместителем руководителя государственной или муниципальной образовательной организации высшего образования и руководителем ее филиала.

При этом наличие действия оскорбления может являться не только фактом, который является элементом состава правонарушения, но и доказательным фактом. Например, статья 336 Трудового кодекса. Оскорбление как действие входит в состав некоторых правонарушений на альтернативной основе. Например, статьи 107, 113 Уголовного кодекса. Оскорбление как определенное действие является обязательным элементом состава объективной стороны. Например, статьи 5.61 КоАП, 319 Уголовного кодекса и др. [2, с. 77].

Определение оскорбления как правонарушения дается в Ч.1 Статьи 56.1 КоАП: «оскорбление, то есть унижение чести и достоинства другого лица, выраженное в неприличной или иной противоречащей общепринятым нормам морали и нравственности форме».

При этом, следует отметить, что диспозиция данной статьи не столь давно претерпела редакцию (от 09.03.2021, вступила в силу с 27.03.2021), ср. текст в предыдущей редакции: «оскорбление, то есть унижение чести и достоинства другого лица, выраженное в неприличной форме».

То есть диагностический признак неприличной формы расширился.

Таким образом, понятие оскорбления как феномена права сводится к выявлению двух основных фактов: 1) унижения чести и достоинства другого лица; 2) неприличной или иной противоречащей общепринятым нормам 
морали и нравственности формы; 3) публичности (для определенных категорий дел).

Схематично состав правонарушения можно определить следующим образом.

Оскорбление

$$
=
$$

унижение чести и достоинства

неприличная или иная противоречащая

общепринятым нормам морали и нравственности форма

$$
\begin{gathered}
+ \\
\text { публичность }
\end{gathered}
$$

(КоАП 5.61. ч. 2; УК 319).

Таким образом, юридическое определение оскорбления как унижение чести и достоинства, выраженное в неприличной или иной противоречащей нормам морали и нравственности форме, ставит перед лингвистами решение определенных теоретических задач языкознания. Смежный, прикладной характер направления юрислингвистики заставляет исследователей чутко реагировать на все изменения в законодательстве, пересматривая некоторые более-менее устоявшиеся в их сознании понятия.

\section{2 Проблемы определения лингвистических признаков оскорбления}

Оскорбление связывают с таким понятием, как речевая агрессия [5;6].

Речевая агрессия - это отражение в речи агрессии психологической, социальной, то есть агрессии «как любой формы поведения, нацеленного на оскорбление или причинение вреда другому живому существу, не желающему подобного обращения» (Р. Бэрон, Р. Ричардсон) [7, с. 42]. Существуют две противоположные точки зрения на природу агрессии: этологическая теория и теория фрустрации [7, с. 44-45]. Согласно этологическому подходу, агрессия свойственна человеку по самой природе, на уровне инстинкта, чем объясняются 
трудно поддающиеся обоснованию войны, политическая и религиозная борьба [8]. По замечанию К.С. Гаджиева, разделяющего эту точку зрения, агрессивность связана с такими человеческими качествами, как честолюбие, устремлённость к активному действию, ориентация на успех. Эти качества требуют выхода, ибо постоянное подавление их тяготит человека и чревато негативными последствиями для него [9, с. 451]. Теория фрустрации видит причину человеческой агрессии во внешних раздражающих обстоятельствах [7, c. 44-45].

Наверное, следует признать отчасти справедливость и той, и другой теории. Агрессия на инстинктивном уровне, действительно, присуща человеку. А внешние факторы - это толчок к агрессивному взрыву. Но есть и другие внешние факторы, которые, часто, наоборот, тормозят выход агрессии наружу. Ведь не стоит забывать о том, что человек - существо не только биологическое, но и социальное. Это хорошо видно на примере политического дискурса, где на речевое поведение, с одной стороны, влияют условия жёсткой политической борьбы, а с другой, - чувство политкорректности. Иной вопрос, насколько будет преобладать тот или другой фактор в определённой ситуации и насколько он вообще значим для определённого субъекта коммуникации.

Оскорбление (наряду с издевкой) считают одним из проявлений речевой агрессии, связывая ее со стратегией дискредитации [10, с. 167-177; 11]. В целом, эта стратегия работает в рамках речевого воздействия «игры на понижение» $[10$, с. 160$]$. Основной особенностью тактики оскорбления является отрицательная оценка [10, с. 161], причинение ущерба противнику [12]. То есть оскорбление связано с выражением отрицательной оценки, направлено на понижение статуса адресата, причинение ему вреда.

Лингвистически, на лексико-фразеологическом уровне, мы соотносим оскорбление с инвективами. При этом, необходимо отметить, что речь пока идет только об оскорбительном «заряде», то есть способности оскорбить. Итак, на лексико-фразеологическом уровне оскорбительно «заряженными» являются 
инвективные слова и фразеологизмы. «Инвективную лексику и фразеологию составляют слова и выражения, заключающие в своей семантике, экспрессивной окраске и оценке оскорбление личности адресата, интенцию говорящего или пишущего унизить, оскорбить, обесчестить, опозорить адресата своей речи (или объекта оскорбления), обычно сопровождаемую намерением сделать это в как можно более уничижительной, резкой, грубой или циничной форме (реже прибегают к «приличной» форме - эвфемизмам, вполне литературным)» [13, с. 75].

Исследователями дана, на наш взгляд, вполне исчерпывающая характеристика данных слов и фразеологизмов, которой вполне можно руководствоваться при выявлении «оскорбительного заряда» слов и фразеологизмов.

Взяв за основу типологию В.Н. Базылева, Ю.А. Бельчикова, А.А. Леонтьева, Ю.С. Сорокина [13, с. 65-82], представим следующую классификацию инвективов, дополнив и скорректировав еe с учетом принадлежности слова литературным/нелитературным разновидностям языка, выражения негативной оценки, эмоционально-экспрессивной окраски.

I. Нелитературные бранные слова и фразеологизмы: просторечные, диалектные, жаргонные, обсценные (матерные).

II. Литературные (принадлежащие периферийным пластам разговорной речи, граничащим с просторечием и жаргонами, грубопросторечные) бранные слова и фразеологизмы: гад (перен.), гаденыши (перен.), гадина, гнида (перен.), подльй, подлюга, сволочь, скотина (перен.), стерва.

III. Литературные слова и фразеологизмы:

1. Констатирующие номинации лица, обозначающие негативную с точки зрения интересов общества (или его большинства) деятельность, занятия, поступки, поведение кого-либо, например: бандит, вор, мошенник, педераст, проститутка, фашист, ипион. 
2. Слова и словосочетания, в самом значении которых при констатирующем характере семантики содержится негативная оценка деятельности, занятий, поведения кого-либо, сопровождаемая экспрессивной окраской публицистического характера. Например: антисемит, двурушник, изменник, предатель, расист, ренегат, русофоб, юдофоб...

3. Нейтральные номинации лица по его профессии, роду занятий, например: бюрократ, коновал, мясник, чиновник, которые в переносных значениях приобретают резко негативную оценку, обычно сопровождаемую экспрессией неодобрения, презрения и т.п. Например: Бюрократ... 2. Неодобр. Должностное лищо, выполняющее свои обязанности формально, в ущерб делу; формалист, буквоед... (Словарь... под ред. А.П. Евгеньевой, т. I, с. 131); Коновал... - 2. Разг., пренебр. О плохом, невежественном враче (там же, т. II, с. 91); Мясник...

4. Зоосемантические метафоры, содержащие, негативные оценки адресата речи и грубую экспрессию неодобрения, презрения, пренебрежения и т.п.: былдо, кобель, кобыла, рыло, свинья, свиное рыло, сука, сукин сын, а также метафоры с исходными понятийными сферами «Война», «Преступный мир» [7, c. 50].

5. Слова, обозначающие действия или качества, свойства кого-либо или чего-либо. Среди таких слов есть слова констатирующей семантики: украсть, убить, мучить, издеваться, насиловать, хулиганить, врать, воровать и слова оценочные, с яркой экспрессивной окраской: хапнуть, двурушничать, лищемерить, лихоимствовать, прикарманить.

6. Слова и словосочетания, в самом значении которых заключена негативная (бранная) оценка кого-либо как личности, с достаточно сильной негативной же экспрессией: дурак, гадина, гнусный.

7. Словосочетания, представляющиеся эвфемизмами: женщина легкого поведения, падшее создание, стоять на панели, агент иностранных спецслужб. 
8. Окказиональные образования, создаваемые с целью оскорбить, унизить адресата, подчеркнуть со стороны говорящего (пишущего) активное неприятие адресата, его деятельности, поступков, презрение к нему и т.п.: коммуняки, иудокоммунисты, дембанда.

9. Прозвища: Жир, Либералиссимус всея Руси, Сын юриста, Владимир Юристович, Вервольфович, Владимир Дьявольфович Вожжириновский, Красный Папа Зю, Лысый Чебурашка, Крокодил Гена, Гендиру Зюганди, Зюзя, Капээсэсня, Сатанидзе, Жирик, Зю, дядюшка Зю, Зюганыш, Хрущ кукурузный, царь Борис, Борис кровавыцй [14, с. 299].

Во всех рассмотренных примерах имеет смысл говорить лишь о способности оскорбить. Ведь даже наиболее агрессивно заряженные из них в определенной коммуникативной ситуации могут не стать оскорбительными, например, матерные слова и сочетания в функции междометий: «Ты, с*ка, че делаешь?» [2, с. 100, см. также: 3, с. 16], а также использованные говорящим только «себе под нос» или в отсутствие слушателей [3, с. 17]; а слова и выражения, не вошедшие в вышеприведенный перечень, вполне могут явиться оскорбительными, например, вполне безобидные слова, попавшие в один квазисинонимический ряд с грубыми бранными словами (о квазисинонимической ситуации см. подр. [15]): $c^{*} \kappa a$, дочь наркомана (пример из лингвистического исследования). Поэтому вывод о том, что данные слова и фразеологизмы являются оскорбительными, можно сделать только при анализе коммуникативной ситуации, с позиций речевого жанра оскорбления [16; 2 и др.].

Итак, мы определили, что на лексико-фразеологическом уровне оскорбление = инвективная лексика и фразеология.

Следующий вопрос, который необходимо решить, как инвективы характеризуются с точки зрения приличной/неприличной формы выражения. Иными словами, все ли слова, перечисленные в вышеприведенной классификации, можно квалифицировать как неприличные. 
Вопрос о неприличной форме решается в науке по-разному. Одни исследователи считают, что однозначно (со строго научнолингвистической точки зрения) к таким наименованиям можно относить только нецензурные единицы, то есть матерные слова, круг которых ограничен: «... пятью словами - нецензурными обозначениями мужского и женского половых органов (две единицы - на $n$. и и на $M .$. ), нецензурное обозначение процесса совокупления и нецензурное обозначение женщины распутного поведения на б..., а также все образованные от этих слов языковые единицы, то есть содержащие в своем составе данные корни» [3, с. 16]. Другие исследователи, ставя во главу угла иную шкалу квалификации, максимально расширяют это понятие: «оскорбление как форма речевого поведения оценивается как неприличная, и в данном случае не является важным, в какой форме (обсценной, просторечной или литературной) было выражено оскорбление» [2, c. 107].

Это две крайние точки шкалы, между которыми располагаются единицы с разной степенью неприличия. Так, например, И.А. Стернин связывает понятие приличной/неприличной языковой формы с нормативности/ненормативности. То есть «приличная лексика, приличная языковая форма выражения мысли - это использование нормативной (приличной) лексики и фразеологии» [3, с. 14]. Относя к ненормативной лексике 4 группы слов - сниженную, вульгарную, бранную и нецензурную, исследователь однозначно относит к неприличной нецензурную (матерную) лексику; сниженную, вульгарную, бранную считает некультурной - то есть неуместной, не рекомендуемой в общественном месте [3, с. 13-18]. «При этом сниженная, вульгарная и бранная лексика не относится к неприличной, она остается ограниченной в употреблении, неуместной в публичном употреблении, но не неприличной в строго научном понимании» [3, с. 20]. Расширительное понимание неприличной лексики исследователь считает ненаучным, обыденным. 
На наш взгляд, в свете новых поправок в КоАП 56.1 от 09.03.2021, где формулировка оскорбления расширяется: «...выраженное в неприличной $\underline{\text { и }}$ иной противоречащей общепринятым нормам морали и нравственности форме» [4] следует уточнить такие понятия, как мораль, нравственность.

Мораль и нравственность - это центральные этические категории.

Мораль - «совокупность принципов и норм поведения людей по отношению друг к другу и к обществу, нравственность» [17, т.2., с. 298]. Нравственность - «совокупность норм поведения человека в каком-л. обществе [17, с.т.2, с. 513]. Норма - «обычный, общепринятый, обязательный порядок, состояние чего-л.» $[17$, т.2., с. 508]. То есть мораль и нравственность - это то, что соответствует нормам, то есть общепринятым, обязательным правилам общественного поведения человека. Это, на наш взгляд, расширяет квалификацию «неприличной и иной противоречащей общепринятым нормам морали и нравственности формы», соотнося с ее понятием инвективной лексики и фразеологии (см. классификацию, представленную выше). При этом, соотнесем понятие неприличной формы с п. I, II представленной выше классификации инвективной лексики и фразеологии, понятие иной противоречащей общепринятым нормам морали и нравственности формы с п. III классификации.

То есть, по факту, юридическая формулировка в новой редакции снимает многие споры по поводу второго диагностического признака оскорбления, дает большую свободу лингвистам в соответствующей квалификации единиц. С другой стороны, она несколько «размывает» границы неприличной лексики и фразеологии, заставляет лингвистов пересмотреть некоторые устоявшиеся в их сознании понятия.

Таким образом, в ходе решения обозначенных вопросов можно сделать следующее заключение: оскорбление = инвективы = единицы, выраженные в неприличной или иной противоречащей общепринятым нормам морали и нравственности форме. При этом неприличная форма = нелитературные 
бранные единицы + литературные (принадлежащие периферийным пластам разговорной речи, граничащим с просторечием и жаргонами, грубопросторечные) бранные единицы; иная противоречащая общепринятым нормам морали и нравственности форма = литературная (связанная $\mathrm{c}$ выражением негативной оценки). При этом речь идет лишь об оскорбительном «заряде» инвективной лексики и фразеологии, то есть способности оскорбить. Сделать окончательный вывод, является ли анализируемая единица средством оскорбления, можно, только проанализировав ее употребление в определенном акте коммуникации (с позиций РЖ оскорбления, с использованием метода РА).

\section{3 Методы и методики исследования речевых признаков оскорбления}

Исследователи отмечают, что вопрос методов исследования спорных текстов сегодня является актуальным. Так, Н.Д. Голев отмечает, что «имеется необходимость выработки общих принципов и конкретной методики юрислингвистической экспертизы, способной эффективно совмещать лингвистическую иправовую оценку конфликтных языкоречевых ситуаций, вовлекаемых в сферу юрисдикции», [18, с. 16].

Однозначно ответить на вопрос, являются ли лексико-фразеологические средства инвективными (то есть оскорбительными), можно решить, проанализировав речевой жанр оскорбления с использованием метода теории речевых актов. Суть теории речевых актов [19, с. $18-19 ; 20$, с. $287 ; 2$, с. $54 ; 21]$ в том, что «лингвист на самом деле анализирует не семантику употребленных слов и выражений, он анализирует действия, совершенные с помощью слов» [20, с. 286]. Примечательно, что и по третьему диагностическому признаку оскорбления (касающегося публичности), актуальный по некоторым категориям дел, возможно ответить, лишь проанализировав речевой акт оскорбления.

Актуальным будет также использование метода дискурсивного анализа, позволяющего привлекать к анализу широкий контекст коммуникативной ситуации $[14$, с. $31-33]$. 
При анализе речевых средств жанра оскорбления эффективными являются также методы:

- лексико-семантического и семантико-синтаксического анализа (определение значения слов, словосочетаний, предложений в контексте высказывания и сверхфразового единства);

- компонентного анализа (выявление оценочного компонента в структуре лексического значения, определение коннотаций [22]);

- лингво-стилистического анализа (определение стилистически окрашенных экспрессивных единиц);

- функционально-стилистического анализа (определение регистра общения участников коммуникации, обусловленность текста регистром общения, стилистическая уместность/неуместность употребления единиц);

- концептуального анализа («направленного на выявление наиболее важных для автора речевого произведения понятий, актуализируемых в тексте высказывания, и возможностей их интерпретации с учетом интра- и экстралингвистического контекста» [23, с 154-195]);

- грамматического анализа (определение грамматических значений на морфологическом и синтаксическом уровне) и др.

\section{4 Анализ речевого жанра оскорбления}

Возьмем за основу характеристику речевого жанра (РЖ) оскорбления, представленную в $[16$, с. 94-98; 24], с некоторыми уточнениями и дополнениями.

В структуру РЖ оскорбления входят:

1) участники конфликтной ситуации: инвектор (тот, кто оскорбляет) и инвектум (тот, кого оскорбляют) с учетом следующих характеристик: количество и соотношение участников конфликта; социальный статус конфликтеров (пол, возраст, должность/ранг, профессия). По замечанию Бринева, инвектор и инвектум - это обязательные участники, помимо них, в 
конфликтной ситуации может быть задействован «участник 3 » (наблюдатель) как факультативный участник [2, с. 95];

2) форма передачи сообщения (письменная / устная);

3) характеристика конфликтной ситуации (контекст), включающая причину возникновения речевого конфликта, фоновую информацию, предмет и причину разногласий;

4) характер конфликтного взаимодействия (контакт), обусловленный особенностями коммуникативного развертывания конфликта, отношениями между конфликтующими сторонами и т.п.

5) языковой код, способствующий развертыванию конфликтной ситуации в речевой конфликт (наличие инвективной лексики, нарушение этикетных норм и т.п.).

1. Участники конфликтной ситуации.

Участников конфликтной ситуации можно классифицировать следующим образом.

I. Обязательные участники.

1) По юридической закрепленности статуса:

А) Участники с закрепленным в законодательстве статусом:

- инвектор и инвектум с закрепленным статусом: со сменой статуса инвектора и инвектума - военнослужащий, начальник, подчиненный (УК, статья 336); инвектор - осужденный, инвектум - представитель администрации исправительного учреждения (УИК 116);

- инвектум с закрепленным статусом: представитель власти (УК 139), участник судебного разбирательства, судья, присяжный заседатель или иное лицо, участвующее в отправлении правосудия (УК 297);

- инвектор с закрепленным статусом: лицо, замещающим государственную или муниципальную должность либо должность государственной гражданской или муниципальной службы (КоАП 5.61). 
В данных случаях социальные роли определены, ситуация общения официально-деловая, строго кодифицированная, которая требует определенных правил речевого поведения и не терпит нарушений. Особенно это актуально для квалификации речевого высказывания как приличной/неприличной формы.

Б) Участники с незакрепленным статусом: лицо/лица (КоАП 5.61, УК 107,113$)$, чье наполнение в каждом конкретном случае может быть различным, и характеристика требует «реконструкции». Чаще всего это бытовая или публицистическая сфера общения, что уже само по себе накладывает отпечаток на выбор речевых средств. В случае квалификации неприличной формы выражения это вызывает определенные затруднения. В разговорной речи (и в современной публицистической с ее демократизацией) - иные, некодифицированные нормы, и многое, что недопустимо в книжных стилях (и особенно, в официально-деловом), по нормам разговорной речи, считается нормальным [25].

2. По участию в коммуникативном акте:

А) непосредственные участники - участники, непосредственно участвующие в коммуникативной акте (инвектор и инвектум). Например, конфликт между соседями в следующей ситуации. Участник 1 (инвектум) приехала к дедушке и бабушке в село. Вечером они собрались с дедушкой выехать в магазин за продуктами. Когда они вышли из дома, на улице в метрах 30 -ти от дома стояла соседка (Участник 2, инвектор) и кричала что-то в сторону Участника 1; когда та начала снимать на телефон, Участник 2 крикнула в сторону Участника 1: «С Укка, дочь наркомана!» (пример из лингвистического исследования). Это самое типичная ситуация оскорбления, когда наблюдается непосредственное участие конфликтеров в диалоге.

Б) косвенные участники (только инвектум) - наблюдается в том случае, когда инвектум участвует в акте коммуникации опосредованно, через третье лицо (третьи лица). Это, по определению Бринева, дистантный речевой акт оскорбления» [2, с. 96]. Например, публичная переписка двух знакомых 
(Участника 1 и Участника 2). Участник 1 попросил Участника 2 познакомить его с девушкой (Участником 3), Участник 2 дал ссылку на страничку Участника 3 на сайте знакомств. Участник 3 не изъявила желание общаться с Участником 1. Участник 1 пожаловался Участнику 2: «Сразу блокирует. Твоя знакомая». В ответ на эту реплику участник 2 ответил: «как $\mathrm{x}^{*}$ и и нам $\mathrm{c}^{*}$ ть в сауне за деньги не отказывалась» (пример из лингвистического исследования). В данном случае инвектум - косвенный участник, об оскорбительном выпаде в свой адрес участник 3 узнает из публичной переписки.

Акцентируем внимание, что инвектор и инвектум - обязательные участники речевого акта оскорбления. Если нет инвектума, то нет и оскорбления. Не может быть безадресного оскорбления. Например, неустановленные лица в парке на свежеокрашенных элементах детской площадки, а также вновь установленном оборудовании нанесли нецензурные рисунки и слова (пример из лингвистического исследования). В данной ситуации нет и не может быть конкретного инвектума, поэтому нельзя отнести данную ситуации к жанру оскорбления.

II. Факультативные участники - это третье лицо (третьи лица).

При дистантном речевом акте это третье лицо служит «каналом передачи информации об оскорблении лица» [2, с. 96] и становится уже обязательным участником ситуации оскорбления [10, с. 165]. На языке описания, принятом в [26] это выглядит следующим образом:

«А) Знаю, что X способно причинить тебе психологический ущерб

Б) Хочу, чтобы ты знал, что я говорю $\mathrm{X}$

В) Говорю X по отношению к тебе третьему лицу $\mathrm{У}$

Г) Знаю, что У передаст тебе, что я говорил X

Д) Говорю Х для того, чтобы причинить тебе психологический ущерб» [2, c. 96]. 
Более того, при дистантном речевом акте третье лицо выполняет двойную функцию: является каналом передачи информации и создает условие публичности.

При непосредственном участии инвектума а акте коммуникации третьи лица выполняют лишь одну функцию - создают условие публичности оскорбления.

Условие публичности актуально для таких категорий дел:

- КоАП. Статья 56.1. Ч.2. Оскорбление, содержащееся в публичном выступлении, публично демонстрирующемся произведении или средствах массовой информации либо совершенное публично с использованием информационно-телекоммуникационных сетей, включая сеть "Интернет", или в отношении нескольких лиц, в том числе индивидуально не определенных;

- УК. Статья 319. Ч. 1. Оскорбление представителя власти: публичное оскорбление представителя власти при исполнении им своих должностных обязанностей или в связи с их исполнением

- УК. Статья 297. Ч 1. Неуважение к суду, выразившееся в оскорблении участников судебного разбирательства. Ч 2. То же деяние, выразившееся в оскорблении судьи, присяжного заседателя или иного лица, участвующего в отправлении правосудия. Компонент публичности имплицитно не сформулирован, но поскольку суд относится к публичным процедурам, то публичность предполагается самой коммуникативной ситуацией;

Но и для таких категорий дел, где публичность не является обязательной квалификацией (например, КоАП. Статья 56.1. Ч. 1), она важна как «усилитель» оскорбления: «...оскорблять можно и один на один, но присутствие посторонних лиц усиливает перлокутивный эффект» [10, с. 165]).

Таким образом, участники конфликтной ситуации могут быть обязательными и факультативными. Обязательные участники - инвектор и инвектум. Последний может быть непосредственным и косвенным, в этом случае обязательным становится участник(и)-наблюдатель(и), который является транслятором оскорбительного выпада и, с другой стороны, фактором 
публичности оскорбления. Среди обязательных участников существует дифференциация по наличию/отсутствию юридической закрепленности статуса. Здесь наблюдается прямая взаимосвязь с регистрами общения. Участники с закрепленным (прописанным) статусом характеризуют официально-деловой стиль общения, участники с незакрепленным (непрописанным) статусом - разговорный и публицистический стиль. Это накладывает свой отпечаток на характеристику приличной/неприличной формы. То, что в официально-деловом стиле однозначно не допускается, то вполне возможно (хотя и с оговорками) в разговорной речи.

\section{2. Форма передачи информации.}

Данная характеристика имеет важное значение, так как устная, непосредственная, спонтанная речь принципиально отличается от письменной, подготовленной (и потому более продуманной). Характерные черты устной речи - неподготовленность, линейность, необратимость, связь с физическим временем осуществления речи - повышают «автоматизм и случайность в употреблении языковых средств, снижают сознательность их отбора» [27,c. 567]. Именно поэтому в случае устной ситуации общения больше риска оскорбить человека случайно, непреднамеренно, неудачно выразившись. Этому способствуют также характерные для устной речи языковые особенности, среди которых заметное место занимает активное употребление средств эмоционально-оценочного характера, разговорных элементов [27, с. 568] (которые, как уже говорилось выше, «работают» на оскорбление). Вместе с тем, исследователи в качестве обязательного условия оскорбления отмечают намеренное причинение психологического ущерба. См., например, ситуацию оскорбления: 

А) $\underline{\text { Знаю, }}$ что X способно причинить тебе психологический ущерб.
Б) Хочу, чтобы ты знал, что я говорю X.
В) Говорю X, чтобы причинить тебе психологический ущерб» (выделено мною) [2, с. 95-96].

Поэтому в устной ситуации общения задача эксперта значительно усложняется - необходимо правильно квалифицировать иллокутивную цель высказывания. В письменной речи (например, публицистической), учитывая характер ее подготовленности, возможность случайного, непреднамеренного оскорбления минимизируется. Но при этом возрастает возможность тщательно продуманного завуалированного инвективного смысла высказывания. $\mathrm{Cp}$. ситуации с неявным коммуникативным намерением.

3. Характеристика конфликтной ситуации (контекст).

Здесь анализируются причина возникновения речевого конфликта, фоновая информация, предмет разногласий, взаимоотношения между участниками конфликта, развертывание коммуникативной ситуации.

Характер конфликтного взаимодействия (контакт).

Анализируется в том числе характер публичности / непубличности, особенности коммуникативного развертывания конфликта, отношения между конфликтующими сторонами.

5. Языковой код, способствующий развертыванию конфликтной ситуации в речевой конфликт.

Анализируются инвективные единицы, средства, нарушающие речевой этикет и т.п.

Поскольку речевой акт оскорбления — речевой акт «оценочной, а именно - негативно-оценочной квалификации (квалификативы)» [20, с. 288], то центральная задача анализа речевых средств - выявление негативно окрашенных единиц, работающих на понижение статуса адресата.

Помимо этого, необходимо еще проанализировать негативно окрашенные единицы с точки зрения их формы - приличной/неприличной. 
При этом, по замечанию Т.В. Чернышовой, «лингвист, отождествляющий речевой акт, содержащий оскорбление лица, выраженное любым способом, может (должен) указать на его оскорбительный характер, если, оценивая условия речевого акта, он приходит к выводу о том, что в ходе данного речевого акта через использование оценочной лексики и фразеологии произошло снижение статуса инвектума по отношению к статусу инвектора» [21]. Тем более, что понятие неприличной формы, в свете новых поправок, как уже говорилось выше, расширяется и даже несколько «размывается».

Только полный анализ всех вышеуказанных пунктов сможет позволить прийти к выводам, являются ли высказывание или текст оскорбительными.

Среди признаков оскорбления выделяют также: направленность на человека, направленность против реципиента, не желающего подобного обращения, наличие намерения оскорбить. Именно эти три признака, по мнению О.В. Саржиной, позволяют отличить инвективный контекст от негативно-эмоционально-оценочного [6, с. 260-263].

Из обозначенных характеристик особенно заслуживает внимания иллокутивное намерение, то есть наличие намерения оскорбить. К.И. Бринев, относя иллокутивную цель к одному из обязательных компонентов инвективного речевого акта, связывает еe с условиями успешности: «Участник 1 знает, что высказывание X может причинить ущерб Участнику 2 и хочет, чтобы Участник 2 знал, что в отношении Участника 2 Участником 1 произведено инвективное высказывание» [2, с. 95-96]. С юридической позиции, «установление умысла отличает оскорбление от хулиганства, которое обусловлено вызовом общественному мнению, а не конкретным умыслом» [3, с. 22]. При этом И.А. Стернин отмечает, что наличие умысла на оскорбление устанавливается судом, то есть это не входит в компетенцию лингвиста. Вместе с тем, о наличии умысла косвенно могут свидетельствовать и некоторые лингвистические признаки, например: языковые и коммуникативные маркеры, указывающие на умышленность высказанного оскорбления: фразы типа - 
«пусть все слышат!», «пусть все знают, что ты за человек!»; речевые маркеры намерения («я тебе выскажу!», «чтоб ты знал...») [3, с. 22]. Думается, если в анализируемом тексте представлены речевые маркеры иллокутивного намерения оскорбления, то лингвисту необходимо на это указать.

Что касается перлокутивного эффекта в речевом акте оскорбления, то здесь необходимо отметить следующее. Анализируя дефиниции слов, обозначающих понятие оскорбления и близких с ним понятий, И.А. Стернин приходит к выводу, что «оскорбительная фраза - такое словоупотребление, которое вызывает у субъекта чувство обиды, субъективного огорчения, субъективного недовольства, унижения. Обида есть субъективное негативное восприятие чьих-либо слов или поступков, субъективное психологическое недовольство словами или поступками другого человека в отношении потерпевшего» [3, с. 27]. Ключевым признаком здесь является субъективность. То, что не является обидным для одного, может вызвать чувство обиды у другого. Это зависит от множества факторов, в том числе от личностных. Поэтому совершенно очевидно, что перлокутивный эффект не может считаться определяющим в констатации факта оскорбления.

Таким образом, сделать вывод об оскорбительном характере спорного текста можно, проанализировав его с точки зрения всех характеристик, присущих речевому жанру оскорбления. Это: участники конфликтной ситуации, форма передачи информации (устная/письменная), контекст, особенности контакта, языковой код. Важно при этом помнить, что языковой код, избранный участником конфликтной ситуации - это лишь один из компонентов речевого жанра оскорбления (хотя и самый значительный). При анализе участникам конфликтной ситуации приписываются определенные коммуникативные роли (инвектора, инвектума, наблюдателя). Вместе с тем, необходимо учитывать, что у ряда участников имеются законодательно закрепленные (прописанные) роли: представителя власти, судьи, 
военнослужащего и др. Это закрепляет спорный текст за официально-деловым стилем общения, что нельзя не учитывать в ходе анализа.

1.5 Специфика анализа речевого жанра оскорблений в зависимости от сферы реализации

Анализируя участников речевого акта оскорбления, мы вплотную подошли еще к одной проблеме исследования спорного текста - необходимости учитывать при анализе регистр общения. Четко прослеживается, что все тексты оскорбительного характера подразделяются по сфере функционирования: 1) официально-деловые; 2) публицистические; 3) разговорно-бытовые. Каждый из них имеет свою специфику, не учитывать которую при исследовании, на наш взгляд, невозможно.

\section{Спорные официально-деловые тексты}

Связаны, прежде всего, со следующими категориями дел.

КоАП. Статья 5.61. Ч.1. Оскорбление, то есть унижение чести и достоинства другого лица, выраженное в неприличной или иной противоречащей общепринятым нормам морали и нравственности форме.

КоАП. Статья 5.61. Ч.4. Оскорбление, совершенное лицом, замещающим государственную или муниципальную должность либо должность государственной гражданской или муниципальной службы, в связи с осуществлением своих полномочий (должностных обязанностей).

УК. Статья 319. Оскорбление представителя власти: публичное оскорбление представителя власти при исполнении им своих должностных обязанностей или в связи с их исполнением.

УК. Статья 297. Ч 1. Неуважение к суду, выразившееся в оскорблении участников судебного разбирательства. Ч.2. То же деяние, выразившееся в оскорблении судьи, присяжного заседателя или иного лица, участвующего в отправлении правосудия.

УК. Статья 336. Ч. 1. Оскорбление одним военнослужащим другого во время исполнения или в связи с исполнением обязанностей военной службы. 
Ч.2. Оскорбление подчиненным начальника, a равно начальником подчиненного во время исполнения или в связи с исполнением обязанностей военной службы.

Сферу распространения очень важно учитывать в связи с тем, что требования к речевому оформлению разных функциональных стилях неодинаково. Так, для официально-деловой речи характерна, наряду с другими особенностями, «особая официальность выражения и безэмоциональность» (своего рода «сухость»)» [28, с. 327-328]. Не случайно, по замечанию исследователей, официально-деловой стиль «долгое время оставался «нелюбимым ребенком русской стилистики: «Бедный лексически, однотонный по содержанию, лишенный, кроме моментов официального холопства, всякой другой эмоциональности, не пользующийся никакой репутацией изысканности и даже отдаленно не претендующий на нее, он, конечно, ничьего внимания при разрешении задач о слоге для изящной литературы к себе не привлек» [29. Цит. по: 28].

Исследователи отмечают, что в последние десятилетия официально-деловой стиль претерпевает изменения под влиянием социально-политических экономических изменений в стране. В частности, расширяется «сфера применения собственно диалогической, субъектно-субъектной коммуникации» [28, с. 336] и др.

То есть общая демократизация в речевой сфере затронула и такую наиболее строгую, безэмоциональную сферу, как официально-деловой стиль: «Развитие официально-делового стиля в последние годы шло в русле демократизации - ведущей тенденции эволюции всего русского литературного языка» [28, с. 340]. При этом, даже применительно к устной официально-деловой речи нормой считается «регламентированность, а также строгое следование этикету» [28, с. 335], несмотря даже на то, что некоторые исследователи отказывают устной речи, имеющей место в сфере делового общения, в статусе официально-делового стиля [30]. 
Поэтому все нарушения речевых норм особенно остро ощущаются именно в условиях реализации официально-деловой речи. И подход к квалификации речевых средств как оскорбительных по указанным выше категориям дел будет, на наш взгляд, более строгим. Так, именно в официально-деловой речи наиболее остро воспринимается нарушение этикетных форм, например, обращение на ты. При этом недопустимо обращение на ты как между официальными лицами, так и между официальным и неофициальным лицом (с разными коммуникативными ролями). Например, обращение на ты врача по отношению к медицинской сестре во время исполнения служебных обязанностей (оба участника коммуникации являются официальными лицами); обращение на ты посетителя официального учреждения по отношению к должностному лицу - представителю организации социальной поддержки, во время исполнения последним служебных обязанностей (адресат - частное лицо, адресант - официальное лицо); обращение на ты коллектора микрофинансовой организации по отношению к клиенту (адресат - официальное лицо, адресант - частное лицо) и т.п. Подобное нарушение этикетных норм усиливает инвективный эффект.

Например, частотны в нашей практике оскорбления в официально-деловой сфере по делам УК, статье 319. Оскорбление представителя власти.

Наиболее типичные ситуации:

- оскорбление имеет место в помещении приемного покоя, куда оскорбляющий, находящийся в состоянии алкогольного опьянения, доставляется представителем власти с целью прохождения медицинского освидетельствования на состояние опьянения (алкогольного, наркотического или иного токсического);

- оскорбление происходит в адрес сотрудника ГИБДД в состоянии алкогольного опьянения в момент составление протокола или предложения со стороны представителя власти к прохождению медицинского 
освидетельствования на состояние опьянения (алкогольного, наркотического или иного токсического);

- оскорбление происходит в иных местах (на улице, в местах общественного пользования и др.) в состоянии алкогольного опьянения.

Сближает все эти ситуации тот факт, что инвектор чаще всего находится в состоянии алкогольного опьянения. При этом обычно в изобилии употребляется неценузрная матерная лексика и фразеология. Подобные исследования для лингвиста являются одними из наиболее простых.

Это могут быть также исследования по делам КоАП, статье 5.61. Оскорбление. Ч.1 (хотя эта категория дел более характерна для разговорной речи), когда речевой акт оскорбления осуществляется в официальной обстановке (на рабочем месте, в присутственном месте). Например, оскорбление врачом медсестры на рабочем месте в рабочее время; оскорбление посетителем центра социальной поддержки населения служащих данной организации во время исполнения служебных обязанностей и т.п.

\section{Спорные публицистические тексты (медиатексты)}

Связаны чаще всего с правонарушениями по статье КоАП 5.61. Ч 2. Оскорбление, содержащееся в публичном выступлении, публично демонстрирующемся произведении или средствах массовой информации либо совершенное публично c использованием информационно-телекоммуникационных сетей, включая сеть "Интернет", или в отношении нескольких лиц, в том числе индивидуально не определенных.

Для медиатекстов (в частности, газетных) характерны следующие признаки: реализация информационной и воздействующей функций (с преобладанием последней); тематическая избирательность и социальная оценочность; наличие структурной и композиционной организации, облегчающей восприятие информации, предназначенной для широкой аудитории; ориентация в выборе языковых средств на определенную читательскую аудиторию, чем обусловлено активное использование 
разговорных единиц; использование разнообразной лексики и стилистических приемов, ориентированных на воздействие и убеждение; неупотребительность просторечно-бранной, сниженной лексики и фразеологии, находящейся за пределами литературного языка [31].

Любое публичное слово, по мнению Т.В. Чернышовой, сопряжено с риском. Медиакоммуникация является наиболее потенциально конфликтной сферой коммуникации. «Критическое осмысление действительности журналистом, публичный характер медиакоммуникации, полиинтенционость и полифункционость медиатекстов, стилевое разнообразие, совокупность разноуровневых лингвистических и экстралингвистических средств, эти и многие другие дискурсивные признаки часто способствуют созданию в медаикоммуникации ситуаций речевого конфликта, для решения которых участники подобных информационных споров вынуждены обращаться в суд» [31, c.68-85].

Основная функция публицистики, как отмечалось выше, информационно-воздействующая (с преобладанием воздействующей). Отсюда - высокая степень экспрессивности, явно выраженной оценочности.

В публицистике экспрессивность достигает порой крайних пределов, переходя в речевую агрессию. Во многом это связано с тем, что публицистический дискурс тесно пересекается с политическим дискурсом, а главное свойство самой политики - агональность, вызванная борьбой за власть. Речевая агрессия, связанная с выражением отрицательной оценки, в публицистике, главным образом, направлена на принижение противника с целью дискредитации в условиях политической борьбы.

Ярко выраженная экспрессивность публицистики связана также с такими особенностями политической коммуникации, как взаимодействие субъектов. Взаимоотношения «субъект↔объект» зачастую представлены разновидностью «вождь↔толпа». Апелляция вождя к образно-чувственному мышлению народа оказывается наиболее действенной, нежели логическое выстраивание 
аргументов. Ведь, по замечанию Г. Лебона, толпа и сама «мыслит образами», она «совсем не отделяет субъективное от объективного» и «считает реальными образы, вызванные в ее уме и зачастую имеющие лишь очень отдаленную связь с наблюдаемым ею фактом» [32]. По словам исследователя, толпа, по самой своей сути обладая преувеличенностью чувств, способна реагировать только на такие же преувеличенные чувства. И поэтому вождь, желающий увлечь её, «должен злоупотреблять сильными выражениями» [32].

Экспрессивность, оценочность медиатекстов также во многом способствуют их конфликтности.

Среди специфичных условий особенностей оскорбления в публицистическом тексте можно выделить следующее.

По замечанию ряда исследователей, для политической коммуникации (как части публицистической) характерна усложнённая модель речевой коммуникации. В качестве её участников выделяют двух адресатов («двух Других», как их обозначила Э. Лассан, опираясь на идею М.М. Бахтина о роли «Другого» в высказывании [33, с. 53-54]): соперник (оппонент) и народ. Так, О.Л. Михалёва, помимо Адресанта ( $\mathrm{Sb}$ политического действия-1), говорит ещё о двух коммуникантах: Sb политического действия-2 - Прямом адресате (слушающем) - сопернике, который может участвовать или не участвовать реально в разговоре; Sb политического действия-3 - Адресате-наблюдателе («народе»), чьего внимания добивается политик, на чьи интересы ссылается [34, с. 36-37]. Такая усложненная политической коммуникации модель распространяется и на акт оскорбления. Так, Иссерс отмечает, что в связи с этим «происходит «раздвоение» коммуникативной задачи: необходимо, во-первых, дискредитировать оппонента в глазах наблюдателя, вызвать у последнего смеховую реакцию, во-вторых, унизить, задеть чувства оппонента. Обе задачи взаимосвязаны: при отсутствии успеха в решении хотя в одной из них ... говорить об оскорблении нельзя» [10, с. 165]. 
При этом, на наш взгляд, учитывая специфику политического дискурса, оскорбление в текстах политической коммуникации не является самоцелью. Основная задача адресанта - воздействие на адресата-наблюдателя (народ) с целью формирования в его сознании определенной, выгодной для адресанта картины мира. Примечательно, что с этой целью используются не только эмоционально-оценочные средства с явным воздействующим эффектом, но зачастую - и суггестивные средства, имеющие скрытый воздействующий эффект [14, с. 324-347]. При этом очень часто в политической коммуникации для достижения основной цели говорящий избирает характерный для речевого акта оскорбления языковой код. Оскорбление - это либо промежуточной этап по пути к главной цели, либо «побочный эффект» в процессе ее достижения.

Здесь имеет место «проактивная инвектива - это оскорбительное вербальное поведение с целью достижения различных внешних выгод. В данном случае нанесение ущерба другим не является самоцелью, оскорбление используется в качестве инструмента для осуществления различных желаний (инвектива-средство)» [6, с. 264].

\section{Спорные разговорные тексты}

Связаны чаще всего с правонарушениями по статье КоАП 5.61.

Ч.1. Оскорбление, то есть унижение чести и достоинства другого лица, выраженное в неприличной или иной противоречащей общепринятым нормам морали и нравственности форме.

Ч.2.2. Оскорбление, содержащееся в публичном выступлении, публично демонстрирующемся произведении или средствах массовой информации либо совершенное публично с телекоммуникационных сетей, включая сеть "Интернет", или в отношении нескольких лиц, в том числе индивидуально не определенных.

Существует довольно четкое противопоставление разговорного стиля и книжных стилей литературного языка. По мнению ряда ученых, разговорный стиль - это особый язык, а не один из функциональных стилей $[25$, с. 5]. 
И это, на наш взгляд, имеет под собой основу. Во-первых, специфичны сами условия реализации разговорной речи, которые принципиально отличают ее от других разновидностей ЛЯ: 1) неподготовленность акта коммуникации, 2) непринужденность акта коммуникации (то есть неофициальность отсутствие официальных отношений между участниками коммуникации; неофициальная обстановка; отсутствие установки на официальное общение), 3) непосредственное участие говорящих в акте коммуникации (то есть диалогичнность) [25, с. 5]. Анализ разговорных текстов показывает, что эти три условия «срабатывают» в большей или меньшей сфере. Так, разговорная речь может быть вполне уместна и в официальной обстановке (например, в офисе во время обеденного перерыва), и в общении между людьми, имеющими официальные взаимоотношения (коллегами). Но выбор речевых средств в этом случае будет более строгим, менее свободным, нежели в ситуации общения в бытовой обстановке между близкими людьми (то есть в типичной ситуации разговорной речи). На наш взгляд, именно непринужденность, то есть неофициальность, акта коммуникации - основная экстралингвистическая особенность разговорной речи, которая в первую очередь определяет выбор речевых средств. Чем непринужденнее обстановка, то есть чем она менее официальна, тем больше разговорная речь проявляется во всех своих особенностях.

Разговорная речь обладает специфическими свойствами, проявляющихся на всех языковых уровнях. Среди основных черт разговорной речи выделяют, в частности, следующие: «наибольшая свобода в выражении мыслей и чувств, то есть его доминантой, организующей речь, является минимум заботы о форме выражения (важно, ЧТО, а не КАК)»; кодификация норм «действует только в пределах общелитературных норм, но даже в этих случаях наименее жестко»; «велика доля окказиональной и персонально-личностной составляющей (говорю и пишу как хочу)» и др. [35, с. 320]. Отмечается также эмоциональная насыщенность разговорной речи. Всё это обусловливает высокую степень ее 
конфликтогенности. К этому стоит еще добавить и преимущественно устный характер разговорной речи со всеми его характеристиками (см. выше). Не случайно поэтому именно в этой сфере общения активна реализация речевых актов оскорбления.

Особенно частотны речевые акты оскорбления в разговорной речи в типичной для нее ситуации бытового общения (на улице, в местах общего пользования и т.п.).

При этом, с учетом того, что в настоящее время набирает обороты виртуальное общение, или «неофициальное публичное взаимодействие членов социума, осуществляемое посредством сети Интернет» [36, с. 334], возрастают случаи оскорблений именно в этой сфере.

Например, оскорбительные комментарии к постам: «Страна должна знать своих «героев», что это мы в тихую можем шлюхаться, пусть видят, пусть помнят... если где-то там чешется ищи свободных мужчин, а то ишь че п... у ней требует перемен! Сочувствую твоему мужу, шлюшка местная! Разбила ни одну семью!» (здесь и далее - орфография и пунктуация автора соблюдены); оскорбительные комментарии к фотографиям: «Шлюха снова бухает»; «Шлюха бухает. Как обычно»; «Шлюха с петухом отдыхают»; «Проститутка»; «Чё на х... смотришь чтоб отс...ть?» и т.п. Примером может служить также публикация информации оскорбительного для определенного лица характера в пабликах типа «ПодслушаноУфа/Бирск/Нефтекамск и т.п.»; публичные комментарии по отношению к третьему лицу и т.п.

Одной из особенности подобных речевых актов является то, что инвектор - чаще всего неустановленное лицо, которое подписывается псевдонимом типа «Иван Иванович» и т.п. При этом задача лингвиста - установить факт наличия речевого акта оскорбления, установление оскорбившего лица - юридическая прерогатива.

Таким образом, сфера реализации спорных текстов (официально-деловая, публицистическая, разговорная) накладывает свой отпечаток на тексты, 
обусловленный особенностями данных разновидностей языка. Поэтому тексты, закрепленные за соответствующим стилем, имеют свою специфику (проявляющуюся во всех характеристиках РЖ), что также надо учитывать в ходе исследования.

1. Изучение имеющегося опыта по теме исследования позволило определить круг проблемных вопросов, связанных с лингвистической экспертизой по делам об оскорблении.

2. Само юридическое определение оскорбления как унижение чести и достоинства, выраженное в неприличной или иной противоречащей нормам морали и нравственности форме, ставит перед лингвистами решение определенных теоретических задач языкознания.

3. К лингвистическим проблемам, связанным с понятием оскорбления, относятся: определение понятия и границ инвективных единиц, определение понятия неприличной и иной противоречащей нормам нравственности и морали формы.

Границы инвективных единиц определяются в классификации, основанной на их соотнесении с литературной/нелитературной разновидностью языка, с учетом выражения негативной оценки, эмоционально-экспрессивной окраски.

С учетом расширения понятия неприличной формы в юридическом плане, инвектива = неприличная и иная противоречащая нормам нравственности и морали форма. При этом неприличная форма = нелитературные бранные слова и фразеологизмы + литературные (принадлежащие периферийным пластам разговорной речи, граничащим с просторечием и жаргонами, грубопросторечные) бранные слова и фразеологизмы; иная противоречащая нормам нравственности и морали форма = литературная (связанная с выражением негативной оценки).

4. В ходе установления лингвистических признаков оскорбления наиболее эффективными методами являются методы теории речевых актов, 
дискурсивного анализа, лексико-семантического и семантико-синтаксического анализа, компонентного анализа, лингво-стилистического анализа, функционально-стилистического анализа, концептуального анализа, грамматического анализа.

5. Вывод о том, что инвективные единицы, имеющие неприличную или иную противоречащую нормам нравственности и морали форму, можно сделать, только проанализировав ее употребление в определенном акте коммуникации (с позиций РЖ оскорбления, с использованием метода РА). При этом все характеристики анализируемой коммуникативной ситуации (участники конфликтной ситуации, форма передачи информации, контекст, особенности контакта, языковой код) должны соответствовать РЖ оскорбления.

6. В ходе анализа языкового кода РЖ оскорбления необходимо учитывать специфику того функционального стиля (официально-делового, публицистического, разговорного), в котором реализуется спорный текст.

7. Лингвистическое исследование спорных текстов должно базироваться на юридической квалификации правонарушения с учетом всех актуальных изменений в законодательстве.

\section{Список литературы}

1. Спорные тексты СМИ и судебные иски: Публикации. Документы. Экспертизы. Комментарии лингвистов / Под ред. М.В. Горбаневского. - М.: Престиж, 2005. - 200 с.

2. Бринев К.И. Теоретическая лингвистика и судебная лингвистическая экспертиза. - Барнаул: Изд-во Алтайского пед. ун-та, 2009. - 251 с.

3. Стернин И.А., Антонова Л.Г., Карпов Д.Л., Шаманова М.В. Выявление признаков унижения чести, достоинства, умаления деловой репутации и оскорбления в лингвистической экспертизе текста. - Ярославль, 2015. - 35 с.

4. Консультант Плюс // Режим доступа: http://www.consultant.ru/ 
5. Кусов Г.В. Диагностика оскорбления: постановка научной проблемы в праве и лингвистике [Электронный дискурс]. - Режим доступа: https://cyberleninka.ru/article/n/diagnostika-oskorbleniya-ostanovkanauchnoyproblemy-v-prave-i-lingvistike-1/viewer

6. Саржина О.В. Оскорбление словом (инвектива) как агрессивный дискурс [Электронный дискурс- Режим доступа: https://cyberleninka.ru/article/n/oskorblenie-slovom-invektiva-kakagressivnyydiskurs-1/viewer

7. Ряпосова А.Б. Метафорические модели с агрессивным прагматическим потенциалом в политическом нарративе «Российские федеральные выборы (1999-2000 гг.): дисс. ... канд. филол. наук: 10.02.01. - Ек-г, 2002. - 202 с.

8. Лоренц К. Агрессия (так называемое «зло»). - М.: Прогресс, Универс, 1994. - 272 c.

9. Гаджиев К.С. Политическая философия. - М.: Экономика, 1999. $606 \mathrm{c.}$

10. Иссерс О.С. Коммуникативные стратегии и тактики русской речи. М.: Едиториал УРСС, 2002. - 284 с.

11. Иссерс О.С. «Посмотрите, на кого он похож!» (К вопросу о речевых тактиках дискредитации) [Электронный дискурс] // Вестник Омского университета. - 1997. - Вып. 3. - С. 81-84. - Режим доступа: http:// www.philology.ru/linguistics2/issers-97.htm

12. Шейгал Е.И. Театральность политического дискурса [Электронный ресурс] // Единицы языка и их функционирование. Вып. 6. - Саратов, 2000. Режим доступа: http://www.philology.ru/linguistics1/sheygal-00.htm

13. Понятие чести, достоинства и деловой репутации: спорные тексты СМИ и проблемы их анализа и оценки юристами и лингвистами / Под ред. А.К. Симонова и М.В. Горбаневского. - М.: Медея, 2014. - 328 с.

14. Карамова А.А. Современный политический дискурс (конец XX начало ХХІвв.): дисс. ... докт. филол. наук: 10.02.01. - Уфа, 2013. - 411 с. 
15. Клушина Н.И. Стилистика публицистического текста. - М.: МедиаМир, 2008 - 244 с.

16. Чернышова Т.В., Голощапова Е.В. Речевой жанр «оскорбление»: основания построения типологической модели (на материале судебных постановлений) // Университетская филология - образованию: регулятивная природа коммуникации. Ч. 1. - Барнаул: Изд-во Алт. ун-та, 2009.

17. Словарь русского языка. В 4 т. / под ред. А.П. Евгеньевой. - М.: Русский язык, 1985-1988

18. Голев Н.Д. От редактора: Актуальные проблемы юрислингвистической экспертизы / Голев Н.Д. // Юрислингвистика-3: Проблемы юрислингвистической экспертизы: Межвузовский сборник научных трудов / Под ред. Н.Д. Голева. - Барнаул: Изд-во Алт. ун-та, 2002. - С. 5-14.

19. Баранов А.Н. Лингвистическая экспертиза текста: теоретические основания и практика: учеб. пособие. - М.: Флинта; Наука, 2011. - 592 с.

20. Радбиль Т.Б., Юматов В.А. Возможности и перспективы применения теории речевых актов в лингвистической экспертизе // Вестник Нижегородского гос. ун-та им. Н. Н. Лобачевского. - 2013. - № 1 (1). - С. 286290.

21. Чернышова Т.В. Методы анализа речевых актов: возможности и проблемы использования в лингвоэкспертной и судебной практике // Acta Linguistica Petropolitana. Труды института лингвистических исследований. 2019. - T.1. - №15.- C. 217-238.

22. Карамова А.А. Категория оценки в современном русском языке: учебное пособие. - Уфа: РИО БашГУ, 2003. - 52 с.

23. Чернышова Т.В. Тексты СМИ в ментально-языковом пространстве современной России: монография. М.: Книжный дом «Либроком», 2009.

24. Голощапова Е.В. Речевой жанр «оскорбление»: описание типологических признаков [Электронный дискурс] // Филология и человек. - 
2014. - № 3. - Режим доступа: https://cyberleninka.ru/article/n/rechevoy-zhanroskorblenie-opisanietipologicheskih-priznakov/viewer

25. Земская Е.А. Русская разговорная речь. Общие вопросы. Словообразование. Синтаксис. - М.: Наука, 1981. - 276 с.

26. Вежбицка А. Речевые жанры [в свете теории элементарных смысловых единиц] / Вежбицка А. // Антология речевых жанров. - М.: Лабиринт, 2007. - С.68-81.

27. Трошева Т.Б. Устная речь // Стилистический энциклопедический словарь русского языка / под ред. М.Н. Кожиной. - М.: Флинта: Наука, 2006. C. 567-569.

28. Кожина М.Н., Дускаева Л.Р., Салимовский В.А. Стилистика русского языка. - М., 2011.

29. Булаховский Л.А. Исторический комментарий к русскому литературному языку. - М., 1975.

30. Колтунова М.В. Язык и деловое общение. - М., 2003.

31. Чернышова Т.В. Современный медиатекст сквозь призму оценочности (на материале текстов, вовлеченных в сферу судебного разбирательства) // Журналистика и культура русской речи. - 2011. - №1 - С.68-85

32. Лебон Г. Психология народов и масс [Электронный ресурс]. - М.: Макет, 1995. - Режим доступа: http://www.klex.ru/xt

33. Лассан Э. Дискурс власти и инакомыслия в СССР. Когнитивно-риторический анализ / Э. Лассан. - Вильнюс: Изд-во Вильнюсского ун-та, 1995. - 232 с.

34. Михалёва О.Л. Политический дискурс: Специфика манипулятивного воздействия / О.Л. Михалёва. - М.: Книжный дом ЛИБРОКОМ, 2009. - 256 с.

35. Сиротинина О.Б. Разговорный стиль // Стилистический энциклопедический словарь русского языка. - М.: Флинта: Наука, 2006. C. 319-321. 
36. Чернышова Т.Б. Типологические черты конфликтного речевого взаимодействия в неофициальном публичном общении (на материале интернет-коммуникации) // Русский язык и литература в пространстве мировой культуры. - 2915. - С. 334-339. 


\title{
ГЛАВА II.
}

\section{ТЕХНОЛОГИЯ ОБУЧЕНИЯ ПИСЬМУ И НАПИСАНИЮ РАЗЛИЧНЫХ ВИДОВ ПИСЬМЕННЫХ ПОСЛАНИЙ НА УРОКАХ РУССКОГО ЯЗЫКА КАК ИНОСТРАННОГО}

\section{Будаева Людмила Николаевна}

кандидат педагогических наук, доцент

Оренбургский государственный медицинский университет

\begin{abstract}
Аннотация: Письмо является одним из видов речевой деятельности. Обучение письму начинается с первых уроков русского языка как иностранного. Целью такой работы является формирование прочного навыка скорописи. Обучение созданию письменных текстов должно проходить поэтапно с последовательным выполнением ряда задач. Использование мобильных сообщений требует от иностранца активного включения в этот вид письменного текста. В данной работе мы предприняли попытку описания методики обучения не только письму, но различным видам мобильных сообщений. Работа над написанием письма имеет свою специфику и предполагает разнообразие технологических подходов. Мы выделили несколько видов деловых документов, необходимых иностранцам - это автобиография, резюме. Автобиография - документ, который обучающийся должен составляет самостоятельно. Резюме - документ, предоставляемый кандидатом при поиске работы. Таким образом, можно сделать вывод, что обучение письму иностранных студентов - это длительный процесс. Такая работа будет эффективной в том случае, если обучение будет вестись в системе, где на каждом последующем уровне изучения языка совершенствуется полученный навык и умение и формируется новый.
\end{abstract}


Ключевые слова: графема, соединение букв, письмо, текстовое сообщение, голосовое сообщение, автобиография, резюме, интерактивный режим обучения, учебная ситуация, ситуационные задачи, матрица оценивания.

\title{
TECHNOLOGY OF TEACHING WRITING AND WRITING VARIOUS TYPES OF WRITTEN MESSAGES IN THE LESSONS OF RUSSIAN
}

\section{AS A FOREIGN LANGUAGE}

\section{Budaeva Lyudmila Nikolaevna}

\begin{abstract}
Writing is one of the types of speech activity. Learning to write begins with the first lessons of Russian as a foreign language. The purpose of such work is to form a strong skill of cursive writing. Training in the creation of written texts should take place in stages with the sequential implementation of a number of tasks. The use of mobile messages requires a foreigner to actively include a written text in this type. In this paper, we have attempted to describe the methods of teaching not only writing, but also various types of mobile messages. The work on writing a letter has its own specifics and involves a variety of technological approaches. We have identified several types of business documents that are necessary for foreigners - an autobiography, a resume. An autobiography is a document that a student must prepare independently. A resume is a document provided by a candidate when looking for a job. Thus, we can conclude that teaching writing to foreign students is a long process. Such work will be effective if the training is conducted in a system where at each subsequent level of language learning, the acquired skill and skill are improved and a new one is formed.
\end{abstract}

Key words: grapheme, letter connection, letter, text message, voice message, autobiography, resume, interactive learning mode, educational situation, situational tasks, assessment matrix. 
Письмо является одним из видов речевой деятельности. При изучении русского языка как иностранного его нередко отводят на второй план, отдавая предпочтение изучению устной разговорной речи. Однако при формировании коммуникативной компетенции необходимо всегда проводить параллель между звуком, его графическим обозначением, поясняя и показывая при этом печатную и прописную графему. Преподаватель начинает обучение с демонстрации начертания русских букв и их соединений, отработки этого навыка и доводит до самостоятельного создания письменных текстов различной сложности. При использовании технологии письма формируются различные компетентности: отрабатываются коммуникативные навыки - точно выражать свои мысли, высказывать свою точку зрения; вырабатывать уверенность в себе и в своих силах, осуществляется самооценка и самокоррекция; развиваются практические компетентности - умение написать письмо и развитие навыка скорописи. Процесс решения ситуационной задачи во время написания письма предполагает «выход» студента-иностранца за рамки учебного процесса [7].

Главными факторами развития личности являются предметно-практическая деятельность и взаимодействие между людьми. Обучение бывает эффективным, если учащиеся активно включаются во взаимоотношения и сотрудничество; получают возможность для анализа своей деятельности и реализации собственного потенциала; не боятся выражать свои мысли допускать ошибки. Все это будет осуществимо при условии, что они не подвергаются порицанию и в результате не получают отрицательной оценки.

Обучение письму начинается с первых уроков русского языка как иностранного. При этом иностранцы сталкиваются с большим количеством трудностей. Так англоговорящие студенты часто путают написание похожих графем. Это написание английской $b$ вместо русской в или английской $u$ вместо русской $y$ в словах с похожим звучанием, например, слово университет, вода. Для студентов из Китая написание русских букв представляет наибольшую 
сложность, так как иерографическое и фонографическое письмо - это два совершенно разных вида письма, которые никак между собой не похожи. Поэтому при обучении письму преподавателю важно уделить внимание и показать написание каждого элемента и соединения, выработать автоматическое письмо.

Нами было проведено исследование и разработаны различные виды упражнений для поэтапного формирования письменной коммуникативной компетенции у иностранных студентов на разных уровнях изучения русского языка как иностранного. Работа над написанием письменных посланий состояла из нескольких этапов, которые осуществлялись нами постепенно с элементарного уровня и до второго сертификационного:

1. Знакомство и отработка умения писать русские буквы и их соединения.

2. Знакомство с разными видами письменных посланий: сообщение, письмо, автобиография, резюме.

3. Отработка умения самостоятельного написания сообщения.

4. Отработка умения самостоятельного написания письма официального и личного характера.

5. Работа над написанием автобиографии и составлением резюме.

6. Анализ и самоанализ выполненной работы.

Практически все эти требования будут соблюдены, если используется интерактивный режим обучения. Поэтому из всего многообразия подходов мы выбрали именно этот метод, при котором взаимодействие происходит в первую очередь между обучающимися, а преподаватель отходит на второй план, только лишь направляя и «подталкивая» к результату. Этот метод направлен на решение конкретной проблемы, которая не дается заранее, а ставится преподавателем совместно с обучающимися с учетом жизненной ситуации и учебной задачи. Иностранцам предлагается самостоятельно подумать над проблемой и найти выход из реальной практической ситуации, поставив перед собой ряд задач, в ходе решения которых и будут усвоены и закреплены 
необходимые знания и умения. Такие ситуации должны быть максимально приближены к современным реалиям и соответствовать требованиям современного «мобильного» общества.

Для отработки навыка графического начертания букв и их соединений мы предложили студентам ряд заданий. Целью такой работы стало формирование прочного навыка скорописи, который необходим иностранным студентам для обучения в российском вузе. На первом этапе студентам было предложено прочитать предложения, запомнить их и записать по памяти. На элементарном уровне можно предложить запомнить простые предложения или небольшой текст. В нем мы советуем указать конкретные имена студентов в группе для более легкого запоминания [5]. Например:

Это мыл. Вот я. А это мой брат. Его зовут Нимиш.

Вот наша собака и наш кот. Они дома.

Здесь наш дом, а там наша машина.

На более позднем этапе изучения русского языка как иностранного можно предложить не только записать предложения, но и выполнить небольшую грамматическую работу. Включение грамматических заданий в упражнения, по нашему мнению, возможно на разных этапах изучения языка и необходимо для отвлечения внимания иностранца от копирования букв, что повысит шансы на увеличение скорости письма [6]. Обучающимся может быть предложено задание закончить предложения: Зимой холодно, а весной ..., или в предложениях подчеркнуть слова, которые отвечают на вопрос «Когда?»: Утром завтрак, днём обед, а вечером ужин. Сегодня урок, а завтра экскурсия. Важным этапом является проверка подобных упражнений. Преподаватель должен обратить внимание каждого обучающегося на неправильное написание элементов и соединений и в случае необходимости предложить написать букву или буквы с соединением еще раз для механического запоминания. 
Для знакомства со структурой письма преподаватель может дать студентам переписать готовое письмо, вставляя пропущенные буквы. Например, мы предложили иностранным обучающимся переписать письмо следующего содержания, вставляя пропущенные буквы:

\section{Привет, Никхил!}

Как твои дела? У меня все хорошо. Я жив в Москв . Москва столииа России. Мне очень нрав ся этот город.

В иентр_находится Кремль, Красн__ площадь, Больш_ театр. Я часто гуля_по иент_. Здесь стар_и_и красив__ здания и улиџь, больш_ пломади, широк__ простектыл. Мне нрав_ся нов _ магазины и иветочн_киоски. Здесь работа симпатичн продавиьл.

Сейчас в Москв_ осень. Погода тепл_. Я часто гуля_в парк_. Осенью парк очень красив_, все листья желт_, красн_, оранжев и зелен

Когда ты приедешь в Москв_? Днём я уч_сь, а в выходные игра в теннис или в волейбол с моими друзьями Вират__ Адари_.

Вечером я, конечно, дела_ домашнее задание, много чита_и пиш_. Мои друзья дума_, что я уже неплохо чита_, пиш_, но ещё плохо понима по-русски .

Я жив_в общежит_. Мои друзья Вират и Адарш тоже жив__зесь. Mbl завтрака_ и ужина_ в комнате, а обеда_ в столовой в университет

Где ты сейчас учишься? В какой стране и в каком городе ты сейчас живешь? Кем ты хочешь стать? Пиши.

Пока-пока.

Твой друг Умеш.

В данном упражнении важна послетекстовая работа, которая включает в себя не только проверку вставленных окончаний, но и поэтапный разбор письма с выделением частей и клишированных фраз. Для понимания структуры 
и особенностей письма мы дали возможность студентам ответить на вопросы на понимание текста письма и обязательных требований к его написанию:

- Кому Умеш написал письмо?

- Где живет Никхил?

- Кто такой Никхил? Брат? Друг?

- Это школьный друг или друг из университета?

- Как вы поняли, что это школьный друг? Прочитайте слова, по которым вы Это поняли.

- Какие вопросы Никхил задал школьному другу?

- Что рассказал о себе Никхил?

- Какие фразы он выбрал для приветствия и прощанья? Запишите эти фразы. Обратите внимание на то, где написал Никхил слова «Привет» и «Пока.

- Какие вопросы он еще мог задать своему другу?

- О чем бы вы рассказали своему школьному другу?

В настоящее время бумажные послания в виде почтового письма уходят в прошлое, их полностью заменили всевозможные виды мобильных посланий. Сообщения могут быть переданы в форме письменного текста в социальных сетях или видео или аудиозаписи с помощью мобильного телефона через Интернет [8]. Мы хотим обратить внимание на современные реалии и предлагаем поработать с иностранными студентами над написанием разных видов писем.

Активное использование мобильных сообщений требует от иностранца активного включения в этот вид письменного текста, его понимания и умения правильно ответить собеседнику. В данной работе мы предприняли попытку описания методики обучения иностранных обучающихся не только письму, но и различным видам мобильных сообщений. Письменные тексты создаются на заранее обозначенную тему в соответствии со всеми нормами и требованиями русского языка. В зависимости от уровня владения языком для иностранных 
студентов средний объем может варьироваться. На элементарном уровне - 8-10 предложений [2].

Так как современное общество активно пользуется различными гаджетами и почти каждый человек имеет личную страничку в социальных сетях, то важной будет работа над написанием сообщений личного и официального характера и, возможно, знакомство обучающихся на более поздних уровнях изучения языка со сленгом, сокращениями, употребляемыми при написании сообщений. Мы советуем проводить работу не только над письменными текстами мобильных сообщений, но и над голосовыми сообщениями. Например, нами было предложено студентам прослушать голосовое сообщение следующего содержания: Привет. Где ты сейчас? Не могу до тебя дозвониться. Позвони мне. Обучающиеся должны прослушать данное сообщение и перевести его в письменную форму. Прежде чем ответить на данное сообщение, мы предложили определить варианты ситуаций, при которых может быть получено данное послание: на уроке - в учебное время, во внеучебное время - на перерыве, после уроков. В зависимости от условия, обучающиеся могут выбрать форму ответа - письменный текст или ответное голосовое сообщение. Текст ответного послания тоже должен быть скорректирован с учетом того, кем было отправлено послание другом, родителями, преподавателем.

Под письмом мы понимаем письменное послание какому-либо человеку: родственнику или другу, которое может быть как официальным, так и дружественным. Работа над написанием письма имеет свою специфику и предполагает разнообразие технологических подходов. Конкретный способ создания проблемной ситуации и организация самостоятельной работы зависит от ряда факторов: степени сложности материала, располагаемого времени, особенности конкретного контингента студентов. Можно использовать следующие варианты проведения занятий: ситуация готовится заранее или методом «инцидента». Можно выделить следующие этапы работы: подготовка 
преподавателем; индивидуальная самостоятельная работа студентов; анализ практической ситуации в группе; подведение итогов. Задачи - ситуации могут выполняться индивидуально и в группе. Но в любом случае целесообразно для каждого студента вести отдельную карточку для оценки выполнения заданий. В данной карточке может располагаться матрица оценивания выполнения задач студентом, вывод педагога о готовности студента к решению практических проблем и соответствующих функциональных умений, рекомендации о том, какие задания студенту необходимо повторить.

На каждом уровне изучения РКИ требования к написанию письма меняются, усложняясь с каждым уровнем. Например, на элементарном и базовом уровне студент получает ряд вопросов, опираясь на которые и последовательно отвечая на них, в результате получает связный текст письма. Такое сочинение направлено на контроль усвоения знаний за период обучения определенному уровню владения языком [3]. При проверке данной работы преподаватель оценивает не только лексическую и грамматическую составляющую, но и правильность написания графем, их соединений. В таком письме важно соблюдать логическую цепочку построения текста с учётом лексического минимума и поставленных вопросов. Перед самостоятельным написанием письма студентами преподаватель должен пояснить не только что такое письмо и его виды, но и показать и научить правильному оформлению текста, правильному изложению мысли (от приветствия к прощанию).

Главное требование при обучении письму - это наличие обращения, кому именно человек адресует свое послание. В этом случае мы предлагаем провести подготовительную работу для того, чтобы иностранцы поняли специфику обращения к человеку в русском языке. На отдельном уроке мы представили обучающимся схему образования полного имени в нашей стране: фамилия имя семьи, имя самого человека и отчество - имя папы с прибавлением суффикса мужского пола -ович/- евич или суффикса женского пола -овна/-евна. Мы предлагаем дать возможность иностранцу потренироваться и самому 
попробовать образовать имя ребенка от данных имен родителей. Так как во многих странах нет отчеств, а речь идет обо всех странах, за исключением постсоветских стран: Украина, Белорусь, Казахстан и других, то и уважительная форма «имя + отчество» иностранцу будет не знакома. Поэтому по привычке англоговорящие студенты употребляют форму ser / ma'am. Причем употребление подобных форм происходит, когда иностранец владеет русским языком на достаточно хорошем уровне, пренебрегая русским уважительным вариантом. Студенты из Китая, переводя на русский язык уважительную форму в Китае, часто говорят «Здравствуйте, преподаватель!» или «Спасибо, преподаватель!». Именно для устранения подобных ошибок преподавателю необходимо разъяснить иностранцу особенности именования в русском языке и варианты дружеской и уважительной формы. Только после того, как обучающиеся поймут и будут употреблять эти формы в речи, мы предлагаем переходить к обучению письму.

Перед обучением написанию письма мы рекомендуем вводить предварительную информацию о самом письме: необходимо дать его определение, рассказать о видах письма: с адресом и до востребования, показать сам конверт и попробовать заполнить адресные данные. Не стоит забывать о телеграммах, почтовых карточках, открытках, преподаватель должен рассказать о ситуациях, в которых они используются. Для лучшего усвоения и запоминания полученной информации важно использовать наглядные пособия: фотографии, картинки, плакаты и конверты, а также мультимедийное сопровождение урока.

После ввода справочной информации преподаватель должен рассказать про адресата, то есть кому мы отправляем письмо: другу, подруге, родителям. Друг или подруга могут быть русскими или иностранцами. На этом этапе обучения написанию письма следует вспомнить об уважительной или дружественной форме обращения. В связи с тем, что во многих языках никак не разграничиваются эти формы или же разграничиваются незначительно, то 
этому моменту нужно особое внимание. Так в английском языка форма местоимения $m b l$ и $B b l$ имеет одинаковое употребление уои, в то время как в русской речи для уважительной формы мы употребляем местоимение $\mathrm{Bbl}$, а на письме обозначаем заглавной буквой. На это нужно обратить особое внимание иностранца [1].

После этого переходим к этапу отработки навыка написания письма. Сначала данное задание можно проговорить устно, а затем использовать эти речевые навыки в ходе написания. Мы предложили иностранным студентам ответить на голосовые мобильные сообщения, поработав тем самым с навыками аудирования. Обучающимся были предложены различные виды голосовых сообщений: от друга / подруги, одноклассников, родителей, родственников, сестры или брата. С учетом всех норм и правил русского языка им нужно было ответить на данные послания. После прослушивания записи важно задавать вопросы на понимание сообщения всеми учащимися. При этом ответ лучше предоставить в виде текста и в виде записи голосового сообщения. Если ответ на сообщение у наших студентов занял небольшое количество времени, то с записью ответного голосового сообщения они работали долго, удаляя непонравившееся и записывая новое послание. Мы рекомендуем написать несколько сообщений со студентами вместе, прежде чем они начнут работать самостоятельно. В это время можно поработать со словарным лексическим минимумом. Эксперимент показал, что такие упражнения позволяют иностранцам со стороны услышать себя, понять свои ошибки и самим оценить себя.

Работа над письмом может использоваться на уроках русского языка как иностранного на этапе закрепления. В некоторых случаях она будет полезна и при введении новой темы в виде подготовительной работы к написанию письма. Задачи должны выстраиваться преподавателем таким образом, чтобы иностранные студенты могли поэтапно продвигаться в знаниях языка. На элементарном уровне преподаватель ставит задачи с низким фактором 
проблемности, позволяя обучающимся самостоятельно решить их без посторонней помощи. Для решения поставленных задач мы предлагали обучающимся следующие задания для подготовки к написанию письменных посланий. На элементарном уровне студенты должны были вспомнить слова приветствия и прощания и разыграть эти диалоги в парах.

1) Здравствуй!

2) Как дела?

3) Можно?

4) До свидания!

5) Привет!

6) Пока!

a) Спасибо, хорошо.

б) Пока!

в) Привет!

2) Здравствуйте!

д) До свидания!

е) Пожсалуйста!

Каждое письмо включает в себя вопросы, которые адресант задает адресату. Это могут быть вопросы о делах, о здоровье, об учебе и другие. Мы столкнулись с проблемой, что обучающиеся порой не могут сформулировать вопрос или заданный вопрос никак не связан с темой письма. Для исправления и коррекции подобных ошибок мы предлагаем включать в обучение написанию письма следующие упражнения. Например, студентам можно предложить прочитать вопросы и ответы и соединить части А и Б, а также самим попробовать сформулировать вопросы. 


\begin{tabular}{|c|c|}
\hline$A$ & $\bar{B}$ \\
\hline Где живет моя семья? & Мои родители работают. \\
\hline Кто ваши родители? & $\begin{array}{l}\text { Моя мама не работает, она } \\
\text { домохозяйка. }\end{array}$ \\
\hline Кем работает твой папа? & $\begin{array}{l}\text { У меня есть брат. Он учится в школе в } \\
\text { Индии. }\end{array}$ \\
\hline Кем работает твоя мама? & $\begin{array}{l}\text { В свободное время моя семья любит } \\
\text { гулять в парке, смотреть дома } \\
\text { телевизор, слушать индийскую музыку. }\end{array}$ \\
\hline $\begin{array}{l}\text { У вас есть брат или сестра? Кем они } \\
\text { работают? }\end{array}$ & $\begin{array}{l}\text { В субботу я учусь в университете, а в } \\
\text { воскресенье моя семья любит гулять в } \\
\text { парке, слушать индийскую музыку, } \\
\text { играть в крикет. }\end{array}$ \\
\hline $\begin{array}{l}\text { Что любит делать вама семья в } \\
\text { свободное время? }\end{array}$ & Мой папа работает врачом. \\
\hline $\begin{array}{l}\text { Что вы обычно делаете в субботу и в } \\
\text { воскресенье? }\end{array}$ & В Индии, в Дели. \\
\hline
\end{tabular}

Деловой русский язык - один из разделов русского языка, изучающий лексические, синтаксические, морфологические и стилистические нормы делового языка. В нашем вузе такая дисциплины как деловая речь и деловой язык отсутствует. Однако, знания в написании деловых документов иностранным студентам важны, так как они - будущие врачи- нуждаются в заполнении медицинских документов. Преподаватель должен помочь овладеть специфическими языковыми средствами официально-делового стиля, развить стилистическое чутьё, познакомить с образцами деловых документов, обучить оформлению и составлению некоторых видов документов [4].

Прежде чем написать деловой документ, иностранный студент знакомится с основными видами деловых документов и выделяет вопросы и ответы, необходимые для их составления. Методически продуманное предъявление грамматического материала и его активизация в системе 
обязательных тренировочных языковых упражнений сочетается с упражнениями и заданиями для обучения всеми видами деятельности, ориентированными на решение коммуникативных задач и осуществление соответствующих речевых действий.

Мы выделили несколько видов деловых документов, необходимых иностранцам - это автобиография, резюме и, в нашем случае, это медицинская карта, а именно - заполнение паспортных данных пациента. Автобиография документ, который обучающийся должен составлять самостоятельно. Резюме документ, предоставляемый кандидатом при поиске работы. Главным отличием автобиографии от резюме является то, что автобиография пишется от руки и повествование ведется от первого лица. Резюме всегда имеет определенную форму, куда человек должен внести все необходимые сведения о своем образовании и карьере. В автобиографии все сведения даются в хронологической последовательности и так, чтобы можно было составить представление о жизненном пути, деловой квалификации и общественно-политической деятельности данного человека. В помощь студентам при написании автобиографии или составлении резюме преподаватель может дать вопросы, ответив на которые иностранец напишет свою автобиографию. На базовом и последующих уровнях мы советуем не давать вопросы, а лишь предоставить план написания автобиографии или план составления резюме.

Наше исследование проводилось со студентами третьего и четвертого курса. Так как они владеют русским языком на достаточно неплохом уровне, поэтому наш план написания автобиографии выглядел следующим образом:

- название документа (автобиография);

- имя, отчество, фамилия автора;

- число, месяи и год рождения;

- место рождения;

- сведения о родителях (фамилия, имя, место работы);

- образование и специальность;

- вид трудовой деятельности; 
- семейное положение и состав семьи;

- домашний адрес и телефон;

- dama;

- nодпись.

Таким образом, можно сделать вывод, что обучение письму иностранных студентов - это длительный процесс. Нами предпринята попытка описания поэтапного обучения письму и созданию различных видов письменных текстов с учетом коммуникативных потребностей обучающихся. Такая работа будет эффективной в том случае, если обучение будет вестись в системе, где на каждом последующем уровне изучения языка совершенствуется полученный навык и умение, формируется новый. При этом конечной целью является формирование умения не только создания письменного текста, но и конспектирование печатного и аудитивного текста, формирования навыка скорописи, что необходимо в процессе получения иностранными студентами образования в российском вузе.

\section{Список литературы}

1. Антонова, В.Е. Дорога в Россию: учебник русского языка (базовый уровень). - М.: ЦМО МГУ им. М.В. Ломоносова; СПб.: Златоуст, 2013. - 256 с.

2. Государственный стандарт по русскому языку как иностранному. Элементарный уровень / Владимирова Т.Е. и др. - 2-е изд., испр. и доп. - М. СПб.: “Златоуст”, 2001. - 28 с.

3. Государственный стандарт по русскому языку как иностранному. Базовый уровень / Владимирова Т.Е. и др. - 2-е изд., испр. и доп. - М. - СПб.: “Златоуст”, 2001. - 23 с.

4. Красивова А.Н. Деловой русский язык: Учебно-практическое пособие. М.: Из-во МФА,2001. С.80.

5. Лексический минимум по русскому языку как иностранному. Элементарный уровень. / Н.П. Андрюшина, Т.В. Козлова - Москва Санкт-Петербург, «Златоуст», 2002. - 80 с. 
6. Лексический минимум по русскому языку как иностранному. Базовый уровень. / Н.П. Андрюшина, Т.В. Козлова - Москва - Санкт-Петербург, «Златоуст», 2002. - 90 с.

7. Современные образовательные технологии и методы обучения: Методические рекомендации / сост. Шепелева Е.Ю. - Балаково: ПКТиМ, 2014 c. 33

8. Толковый словарь русского языка начала XXI века. Актуальная лексика / под ред.Г.Н. Скляревской.- М.: Эксмо, 2007- 1136 с.

\section{List of literature}

1. Antonova, V.E. The Road to Russia: textbook of the Russian language (basic level). - Moscow: TSMO of the Lomonosov Moscow State University; St. Petersburg: Zlatoust, 2013 - - 256 p.

2. The state standard for Russian as a foreign language. Elementary level / Vladimirova T.E. et al. - 2nd ed., ispr. and add. - M.-St. Petersburg: "Zlatoust", 2001. $-28 \mathrm{p}$.

3. The state standard for Russian as a foreign language. Basic level / Vladimirova T.E. et al. - 2nd ed., ispr. and add. - M.-St. Petersburg: "Zlatoust", 2001. $-23 \mathrm{p}$.

4. Krasivova A.N. Business Russian language: An educational and practical guide. - Moscow: MFA Publishing House, 2001. p. 80.

5. Lexical minimum in Russian as a foreign language. Elementary level. I N.P. Andryushina, T.V. Kozlova-Moscow - St. Petersburg, "Zlatoust", 2002. - 80 p.

6. Lexical minimum in Russian as a foreign language. Basic level. I N.P. Andryushina, T.V. Kozlova-Moscow - St. Petersburg, "Zlatoust", 2002. - 90 p.

7. Modern educational technologies and teaching methods: Methodological recommendations / comp. Shepeleva E. Yu. - Balakovo: PKTiM, 2014-p. 33

8. Explanatory dictionary of the Russian language of the beginning of the XXI century. Actual vocabulary / edited by G. N. Sklyarevskaya. - M.: Eksmo, 2007$1136 \mathrm{p}$. 


\title{
ГЛАВА III.
}

УДК 81.373.49

\section{РОЛЬ ЭВФЕМИЗМА В СОВРЕМЕННОМ МИРЕ}

Руденко Елена Евгеньевна

к.П.н., доцент

\section{Потехина Евгения Семеновна}

ФГБОУ ВО Тихоокеанский государственный медицинский университет

Аннотация: В работе отражена растущая роль использования эвфемизмов в современном мире наряду с процессом огрубления речи. Приводятся примеры из медиа источников, известных газет и журналов, а также научно-публицистической и художественной литературы, которые наилучшим образом отражают сегодняшнюю реальность.

Ключевые слова: классификация, коммуникативный конфликт, сфера использования, тенденция, эвфемизм.

\section{THE ROLE OF EUPHEMISM IN THE MODERN WORLD}

\section{Rudenko Elena Evgenyevna}

\section{Potekhina Evgeniia Semyonovna}

\begin{abstract}
The work deals with the growing role of the use of euphemisms in the modern world, along with the process of coarsening speech. Examples are given from media sources, well-known newspapers and magazines, as well as scientific and journalistic and fiction literature, which best reflect today's reality.
\end{abstract}


Key words: classification, communicative conflict, scope of use, tendency, euphemism.

\section{Введение}

Перемены, которые происходят в нашем мире, трудно не заметить. Если внимательнее взглянуть на наш мир сегодня, то можно увидеть несколько сходств и различий. Многие могут сказать, что нахождение сходств и различий было характерно во все времена, однако, сегодня эти сходства и различия принимают другой оттенок. После окончания Второй мировой войны, все страны мира сошлись на мнении, что подобной трагедии больше нельзя допустить. Была выдвинута идея всеобщей безопасности, поддерживаемой всеми странами в совокупности. Можно предположить, что именно этот период является ранним началом глобализации. Конечно, в те времена это явление не было столь характерным как сегодня, но первые шаги были уже сделаны. Страны старались сотрудничать друг с другом на разных уровнях при решении различных глобальных проблем. Создается $\mathrm{OOH}$, подписываются совместные декларации, конвенции, договора, утверждается верховенство международного закона. Наряду с этим явлением происходит технологический процесс и компьютеризация общества. Мир превращается в сложнейшую систему, в определённые моменты напоминающую полную анархию. Международный закон как таковой стал настолько сложен, что теперь на самом деле, возможно, обвинить, кого угодно и потом легко оправдать. Принимая во внимание все эти изменения в мире, люди, выступая на международном уровне, пытаются «выбирать» слова, чтобы не обидеть другую культуру, не нарушить чьи-то права и не породить конфликт - т.е. не нарушить пока основной закон, который объединяет нации сохранение мира и порядка. Стоит отметить, что именно глобализация делает подобное нарушение легко совершаемым. Такой «выбор» слов постепенно ведёт к эвфемизации речи политиков и дипломатов. Другими словами эвфемизация усиливается в нашей социальной жизни под влиянием естественных процессов в мире. Однако именно по этой же причине идёт 
огрубление речи в нашей личной или частной жизни. Л.П. Крысин написал в одной из своих работ: «Одним из проявлений свободы слова, наступившей на рубеже 80-90-х годов, стало снятие запрета на употребление обеденной лексики как в художественных и полу художественных текстах, так и в различных жанрах обиходно-бытовой и публичной речи, в том числе и рассчитанной на массового адресата: матерные слова нередки в современных фильмах, в телевизионных передачах, газетных и журнальных статьях» [1]. Как метко выразилась по этому поводу 3. Кёстер-Тома, «непечатное» слово стало «печатным» [2, С. 26].

В данной работе нами была предпринята попытка отразить эти две тенденции и показать, что эвфемизация социальной жизни в наше время значительно превалирует над эвфемизацией частной или личной жизни. Мы ставим перед собой целью показать растущую важность использования эвфемизмов в социальной сфере в наши дни на ряду с процессом огрубления речи в личной сфере (казалось бы изначально целью эвфемизма было именно «приукрашивание» речи и ничего более). В нашем исследовании мы приведём примеры взятых из теле и радио передач, известных газет и журналов (Совершенно секретно, Московские новости, Независимая газета, Московский комсомолец и т.д.), а также проанализируем ряд других источников. Другими словами мы старались брать аутентичные материалы, которые наилучшим образом отражают нашу сегодняшнюю реальность. Проводя подобный анализ, мы основывались на работах Л.П. Крысина, А.А. Реформатского. Г.Б. Антрушиной, Б.А. Ларина и ряда других учёных.

\section{ОПРЕДЕЛЕНИЕ, РОЛЬ И СФЕРЫ ИСПОЛЬЗОВАНИЯ ЭВФЕМИЗМА}

В этой главе мы подробно будем рассматривать определение эвфемизма, его роль и различные сферы использования. Мы ставим перед собой целью дать общее понимание эвфемизма, то какие роли ему приписывают разные авторы. 


\section{1 Определение эвфемизма}

Слово «эвфемизм» известно человечеству ещё с давних времён, когда на земле хозяйствовали древние племена, жизнь и быт которых были покрыты мистикой. В своих работах известный филолог Б.А Ларин писал, что «суеверная боязнь заклинаний, магического действа зова, прямого наименования породила запреты на слова (табу), породила деление на общие и «сокровенные» слова, дозволенные только жрецам, вождям. Та же вера в магию слова породила молитвы, заговоры болезней, привораживание женихов» [3]. В замену запретных слов создавались новые наименования, чтобы не разгневать богов, обмануть нечистую силу или страшного зверя, чтобы одобрить их. Таким образом, ещё на стадии первобытных суеверий, в силу табу, начинают развиваться древнейшие эвфемизмы, «дозволенные и пристойные наименования, по природе своей перифрастические или образные, скрывающие свой предмет, отвлекающие от его узнавания, якобы превращающие силой словотворчества злые качества, действия в благоприятные, желательные или хотя бы безвредные» [3]. По мнению А.А. Реформатского, такими эвфемизмами были у многих европейских народов, в том числе и у славян, названия змей, медведя. Русское слово змея, и змий буквально значило «земной», а русское медведь - искусственно составленное сложное слово со значением «тот, кто ест мёд» [3].

В Англии эвфемизмы появились в XVI веке с развитием пуританства и стремлением очистить язык от богохульственных слов и получили широкое распространение в XVIII веке, когда в кругах английской знати считалось неприличным называть некоторые вещи своими именами.

Изменилось ли назначение эвфемизма в наши дни? Сказать «да» или «нет» при ответе на этот вопрос весьма тяжело, но ясно только одно - сфера его употребления значительно расширилась. Давайте посмотрим на определения эвфемизма, которое дают создатели некоторых иностранных словарей. В целом все авторы сходятся на том, что эвфемизм - это слово или выражение, 
используемое в качестве замены для грубого или обидного слова (выражения). Так, например, известный английский языковед Коллинз определяет эвфемизм как «вежливое слово или выражение используемое людьми, когда они говорят о чём-то неприятном и неприемлемом» [4]. В качестве примера автор приводит такое распространенное выражение как «средства защитыл», которое в наши дни часто применимо к оружию, военной амуниции и др. Такого же мнения придерживаются The Old Nation English Dictionary, Longman Dictionary и American Heritage Dictionary [5, 6, 7]. Однако New Webster Dictionary даёт немного другую интерпретацию данному слову, говоря, что эвфемизмы - эго «слова или выражения, используемые для срытия нежелательной правды» [8].

Обращаясь к отечественным языковедам, следует признать, что, возможно, самое обширное определение эвфемизма на сегодняшний день дал Л.ІІ. Крысин в своей работе «Эвфемизмы в современной русской речи», в которой автор старался учитывать мнения многих российских и зарубежных языковедов [1]. Л.ІІ. Крысин полагает, что в толковании понятия эвфемизма разными авторами имеются некоторые расхождения. Так, наряду с распространенным пониманием эвфемизма как «слова или выражения, служащего в определённых условиях для замены таких обозначений, которые представляются говорящему нежелательными, не вполне вежливыми, слишком резкими» [9], как «эмоционально нейтрального слова или выражения, употребляемого вместо синонимичных слов или выражений, представляющихся говорящему неприличными, грубыми или нетактичными» [10] - встречается и более узкое осмысление эвфемизма только как «слова или выражения, заменяющего табуизированные слова» $[11$, С. 81$]$.

В дополнение к этим определениям можно сказать, что в отличие от обычной лексики, эвфемизмы особенно чувствительны к общественным оценкам тех или иных явлений. С этим связана историческая изменчивость статуса эвфемизма в языке и речи: то, что представляется удачным эвфемистическим наименованием одному поколению, в следующем поколении 
может расцениваться как несомненная и недопустимая грубость, требующая эвфемистической замены.

«Эвфемизмы недолговечны, - писал по этому поводу Б.А. Ларин, существенным условием действенности эвфемизма является наличие «грубого», «недопустимого» эквивалента. Как только это подразумеваемое, неудобопроизносимое выражение выходит из употребления, эвфемизм теряет свои «облагораживающие» свойства, так как переходит в разряд «прямых» наименований и тогда требует новой подмены» [3].

\section{2 Цели эвфемизации речи}

Верна ли традиционная интерпретация эвфемизма как смягчающего средства, как слова или выражения, заменяющего его, что кажется говорящему грубым и неприличным? Понимание эвфемизма только как смягчающего средства или как способа избежать грубости более или менее удовлетворительно в отношении личных сфер эвфемизации. Но как только мы начинаем касаться социальных сфер и различных способов эвфемизации той речи, которая обслуживает эти сферы, становится очевидной недостаточность представления об эвфемизме как о простой замене грубого или неприличного слова более приемлемым (и для говорящего, и для адресата).

Анализируя цели использования эвфемизмов, мы взяли за основу структуру, которой придерживается Л.П. Крысин. Стоит отметить, что в этом части нашего исследования, после определения цели использования эвфемизма, мы сразу будем приводить пример, чтобы сложилось полное понимание этой цели в спектре нашей жизни. Итак, Л.П. Крысин выделяет три основных цели эвфемизации речи [1].

1. Основная цель, которая преследуется говорящими при использовании эвфемизмов в социальных и межличностных отношениях, - стремление избегать коммуникативных конфликтов и неудач, не создавать у собеседника ощущения коммуникативного дискомфорта. В эвфемизмах этого рода иначе, в более щадящей форме - по сравнению с иными способами номинации - 
называют объект, действие, свойство. Сравним, например, употребляющиеся в функции своеобразных терминов слова слабосльшаащий вместо глухой, незрячий вместо слепой, а также высказывания типа Она недослышит. Он прихрамывает (о сильно хромающем человеке). Да, что-то я приболел температура под сорок. и т.п. Канцелярский штамп заслуженный отдых (покой) в сочетании уйти (проводить) на заслуженный отдых (покой) ощущается говорящими как более вежливое выражение, чем слово пенсия, в особенности если оно употребляется в присутствии лица, о котором идет речь (по-видимому, потому что слово пенсия может вызвать у адресата нежелательные ассоциации с социальной ущербностью). Сравним случаи более индивидуальных эвфемизмов подобного рода: - Присядьте, прошу вас, присядьте - вон те, на балконе, гости! (Председательствующий на съезде народных депутатов, апрель 1992 г. [12]) - здесь словоформа сядьте расценивается говорящим, видимо, как недостаточно вежливая. Или, например, «Это платье вас ... э-э... взрослит» (говорящий избежал слова старит).

2. Более специфической - в социальном смысле - является другая цель эвфемизации: вуалирование, камуфляж существа дела. Эвфемистические средства, используемые для этой цели, весьма разнообразны и характерны, как кажется, именно для нашей языковой действительности. Во времена Советского Союза (языковая действительность которого во многом сохранилась и в наше время) причина этого крылась в общей не благополучности системы и обслуживающего её идеологического аппарата, в боязни огласки неблаговидной или антигуманной деятельности. Недаром камуфлирующие наименования наиболее частотны при описании того, что надо скрывать: жизни лагеря или тюрьмы, работы оборонных предприятий, а в недавнем прошлом - скрытой деятельности верхушки коммунистической партии и госаппарата, работы ЧК/ОГПУ/НКВД /МТБ/КГБ, которые получили устойчивое эвфемистическое наименование компетентные органы. 
Например, лагерь или тюрьма в административно-деловом жаргоне называется учреждение (В это учреждение поступило много новых людей. [13], интервью с работниками МВД); сочетанием отдельно стоящее помещение обозначается штрафной изолятор в лагере в повести Л. Разгона «Непридуманное» [14]; слово надзиратель в последнее время вытеснено более туманным и не столь одиозным контролёр; вместо слова агент или пейоративного стукач говорят информатор или доброжелатель (в речи Рыбина, бывшего охранника И.В. Сталина: Агент неудобно говорить, ну, доброжелатель можно сказать, доброжелатель [13].

Весьма показательны также в качестве «камуфлирующих» многочисленные наименования с первой частью спеи-: спецконтингент (о заключенных или ссыльных), спецотдел (а также особый отдел в воинских подразделениях, в гражданских - первый отдел, что также является эвфемистическим обозначением службы сыска и цензуры), спецраспределеиие, спецсектор. спецзадание, спецполиклиника, спеихран (как сокращенное название отдела специального хранения книг в библиотеке, то есть книг, не выдаваемых читателям без особого на то разрешения), и т.п. [1].

Спецакция и просто акция на этом жаргоне обозначает «расстрел, приведение в исполнение смертного приговора», а словосочетание высшая мера (из высшая мера наказания), эвфемистически обозначающее приговор к смертной казни, стало официальным юридическим термином (который в просторечии и арготическом употреблении стянулся до вышка и вышак). Сюда же примыкает вуалирующее употребление глаголов нейтрализовать и обезвредить в контекстах типа: Надо было нейтрализовать охрану (= перебить, уничтожить). После того, как часовой был обезврежен... (= убит или приведен в состояние, когда он не может действовать), физическое устранение - вместо убийство (В «Вечерней Москве» появилась провокационная статья о якобы готовящемся физическом устранении президента) [13]. 
В военном языке с давних пор употребляются обозначения, с помощью которых от противника скрывается подлинный смысл передаваемых сообщений: хозяйство в значении «воинская часть», огуриы в значении «снаряды» и т.п. Эта традиция была воспринята и при описании деятельности оборонных и всяких иных «закрытых» предприятий: ящик в значении «завод, институт» (Работаю в ящике; Их распределили по ящикам - о выпускниках института) - из сочетания почтовый ящик номер такой-то; объект - в значении «военный объект» или «промышленный объект оборонного характера». Многочисленные примеры употребления слова объект в таком смысле можно найти в "Воспоминаниях" А.Д. Сахарова. Изделие - о бомбе, ракете и тому подобной продукции военного назначения: «Приехав на полигон (для ядерных испытаний), мы узнали о неожиданно возникшей очень сложной ситуации. Испытание было намечено в наземном варианте. Изделие в момент взрыва должно было находиться на специальной башне, построенной в центре испытательного поля; продукт: Продуктом называли начинку для атомных бомб» [13].

Камуфлирующими являются эвфемизмы, которые в недавнем прошлом использовались для обозначения действий и свойств представителей партийного и советского аппарата (любого уровня). Жизнь внутри партийной верхушки и структур власти должна была скрываться от непосвященных, и поэтому сообщения о тех или иных событиях в этих сферах изобиловали весьма расплывчатыми оборотами типа: для служебного пользования - о секретных документах; рассмотрен организационный вопрос (это означало, что какой-либо партийный или советский начальник выведен из состава руководящего органа, понижен в должности и т.п.); были сделаны оргвыводы (обозначение репрессивных мер, примененных к какому-нибудь функционеру или вообще работнику); вести себя нескромно (о партийном хапуге, коррупционере и т.п.); сравним также полушутливое, но от этого не меняющее своей эвфемической сути, жизнелюб применительно к какому-нибудь 
чиновнику пьянице или развратнику. Кое в чем такое словоупотребление сохраняется и в наши дни. Например, «Была отмечена нескромность главы администрации, который использовал свое служебное положение в корыстных целях (т.е. брал взятки, торговал государственным имуществом и т.п.) [16].

В связи с распадом Советского Союза и усилением вражды между некоторыми, прежде «братскими», его народами, сообщения о кровавых событиях в тех или иных районах Кавказа, Средней Азии, Прибалтики, Молдавии и др. также нередко подаются в «вуалирующем», смягчающем тоне, для чего используются эвфемизмы типа: сохраняется напряженность (В Нагорном Карабахе сохраняется напряженность,...имеются убитые и раненые.) [16]; пострадать (В боях пострадало свыше сорока человек, из них восемь убиты.) [13]; пойти на крайние меры (В этой обстановке не желательно было бы пойти на крайние меры и ввести туда войска.) [13]; непредсказуемые последствия (Этот шаг азербайджанского правительства может иметь непредсказуемые последствия: обозреватели сходятся во мнении, что военных действий в Нагорном Карабахе избежать не удастся.) [16].

3. Третья цель, преследуемая говорящим при употреблении эвфемизмов, заключается в стремлении сообщить нечто адресату таким образом, чтобы это было понятно только ему. Разумеется, такого рода зашифрованность сообщения относительна и очень скоро она становится мнимой, если пободные сообщения содержаться не в частной переписке, а публикуются и тем самым делаются доступными для интерпретации каждому читающему или слушающему.

С этой точки зрения весьма характерны разного рода объявления, публикуемые в печати или вывешиваемые у станций метро, на заборах и столбах т.д. «Меняю трехкомнатную квартиру на четырехкомнатную за солидную договоренность». В этом примере за выражением «за солидную договоренность» скрыто обещание хорошо оплатить разницу в площади обмениваемых квартир. Сравним также более характерное: «Меняю 
однокомнатную квартиру на двухкомнатную по очень хорошей договоренности» и даже «Меняю Луганск на Москву за очень хорошую договоренность», где в типе управления проглядывает модель управления того предиката, который заменен эвфемизмом: платить, плата за что-нибудь.

В сфере, которая связана с обменом и получением жилья, немало и других эвфемизмов. Каждому, кто вплотную сталкивался с этой вызывающей тягостные ощущения сферой, хорошо известно, что, например, перспективная семья - это семья, в которой родители находятся в так называемом репродуктивном возрасте, т.е., проще говоря, семья, в которой могут родиться дети. А перспективная квартира - это нечто почти противоположное по смыслу и даже зловеще-бесчеловечное, по сути: квартира, в которой живет престарелый (и, стало быть, неперспективный в только что рассмотренном смысле) человек и которая, следовательно, скоро освободится.

\section{3 Сферы эвфемизации}

Поняв c какой целью люди используют эвфемизмы, давайте повнимательнее посмотрим на сферы эвфемизации. Классификации сфер использования эвфемизмов разных авторов весьма схожи, поэтому в этом параграфе мы рассмотрим три подхода трех, возможно самых компетентных авторов. Прежде всего, стоит обратить внимание на классификацию, данную уже хорошо известным нам Л.П. Крысиным, который выделяет социальную и личную сферы эвфемизации. Причём в личной сфере автор выделяет четыре основных темы эвфемизации. Оценка говорящим того или иного предмета речи с точки зрения приличия/неприличия, грубости/вежливости обычно бывает ориентирована на определенные темы и на сферы деятельности людей (или отношений между ними) [1]. Традиционно такими темами являются:

некоторые физиологические процессы и состояния; сравним: освободи нос! (вместо: высморкай!), освободить кишечник; Она ждет ребенка (вместо: Она беременна) и др.; 
определенные части тела, связанные с «телесным низом»; объекты этого рода таковы, что и непрямое, эвфемистическое их обозначение в бытовой речи воспринимается большинством как не вполне приличное. Сравним, например, просторечные и жаргонные обозначения мужского члена: конещ, палка, инструмент, annapam [17, С. 314]. Среди медиков, как известно, для этих целей используется латынь;

отношения между полами: например, находиться в близких, интимных отношениях, в интимной связи, физическая близость; просторечное употребление глаголов встречаться, дружить, гулять (с кем-либо). Сравним: У нас с ним ничего не было. (Имеется в виду физическая близость, и т.п.);

болезнь и смерть: недомогание, плохо себя чувствовать вместо болеть, хворать: Она совсем плохая (о безнадежно больной), ушел от нас, его не стало (вместо умер), кончина (вместо смерть); летальный исход как медицинский эвфемизм, заменяющий «слишком прямое» смерть и др. Темы смерти и похорон, если эти события актуальны (либо совпадают с моментом речи, либо отделены от него небольшим промежутком времени), вербализуются почти исключительно с помощью эвфемизмов. Сравним: скончаться и устаревшее и просторечное кончиться, усопший. (Хозяина не стало, нет больше с нами. Предать земле (но не закопать.) Действия учреждений, занимающихся организацией похорон, в официальном языке обозначаются расплывчатым и эвфемистическим по своей природе оборотом ритуальные услуги. Сравним также в речи медиков: потерять больного, т. е. допустить, чтобы больной умер, не справиться с болезнью; дети уходят (в значении «умирают»).

Эти темы эвфемизации называются личнылми, так как они касаются личной жизни и личности говорящего, адресата и третьих лиц.

Кроме того, явление эвфемизации наблюдается и в различных сферах социальной жизни человека и общества. Важно подчеркнуть, что в современных условиях наибольшее развитие получают как раз способы и средства эвфемизации, затрагивающие социально значимые темы, сферы 
деятельности человека, его отношений с другими людьми, с обществом, с властью.

Л.П. Крысин выделяет семь тем использования эвфемизмов в социальной cфepe [1]:

Традиционной темой, в которой активно употребляются эвфемистические средства выражения, является дипломатия. Совершенно очевидно, что те коммуникативные задачи, с которыми приходится иметь дело дипломатам и политикам, невозможно решить, используя лишь прямые номинации, обходясь без обиняков, намеков, недоговоренностей, камуфляжа, то есть без всего того, для выражения чего как бы и предназначены эвфемизмы.

Репрессивные действия власти: задержать вместо арестовать (Сравним, в интервью с начальником Главного управления внутренних дел Москвы: - Скажите, кого-нибудь арестовали из участников этой акции? - Мы задержали несколько человек, им будет предъявлено обвинение в умышленном нарушении общественного порядка и злостном хулиганстве [13]. Сюда же примыкают характерные для недавнего прошлого обозначения мер партийного и административного воздействия на людей: предупредить, поставить на вид, указать (как правило, без заполнения валентности содержания): Бюро предупредило Иванова (поставило на вид, указало)...; поправить (Сравним, превратившееся в расхожую шутку: Если я не прав, старшие товарищи меня поправят) и др.

Государственные и военные тайны и секреты, к числу которых относится производство оружия, определенных видов техники, социальный и численный состав учреждений (не только военных), профиль их работы и многое другое. Сравним приводившиеся выше примеры употребления слов объект, продукт, изделие, ящзик и др., а также следующие примеры: разработка необычных видов оружия (имеется в виду бактериологическое оружие), нетрадиционные формы войны (имеются в 
виду формы войны, направленные на полное уничтожение живой силы противника с сохранением его военной техники).

Деятельность армии, разведки, милиции, уголовного розыска и некоторых других органов власти, действия которых не должны быть «на виду». Здесь употребительны слова и обороты с достаточно общим смыслом, в то время как применяются они по отношению к конкретным действиям и явлениям: задание, операчия (идти на задание, выполнить задание, провести операцию по задержанию преступника), объект в значении «лицо, за которым ведется негласное наблюдение» (Сравним: Он уточнил, где находится объект (т.е. Солженицын)... В этот момент я увидел "объекта" с приятелем, выходивших из дверей магазина [18]. Акция, спещиальная акиия (Сравним: На встрече с резидентом КГБ Вадиа Хаддаг изложил перспективную программу диверсионно-террористической деятельности НФОП... Основной целью специальных акций НФОП является повышение эффективности борьбы Палестинского движения сопротивления против Израиля, сионизма и американского империализма, осуществление акицй против американского и израильского персонала... [19], учреждение закрытого типа, жаргонно-профессиональное иметь, получить допуск (без указания объекта: к секретной документации, к секретной работе), невыездной - о человеке, связанном с секретной работой и потому не имеющем возможности ездить за границу (в дальнейшем было распространено на политически неблагонадежных лиц).

Сфера распределения и обслуживания: товары повыменного спроса, дефицитные товары, дефищит («Дефицит выбросили»); в бытовой речи и в просторечии распространены обороты организовать, устроить что-нибудь в значении «содействовать в приобретении какого-нибудь товара»: Устрой мне холодильник за полторы иены. А кухонный гарнитур организовать можешь? 
Отношения между различными национальными и социальными группами, статус этих групп: некоренное население - может быть употреблено применительно к русским, живущим в Прибалтике или других бывших республиках СССР; этническая чистка - уничтожение в том или ином районе (городе, республике) лиц, не принадлежащих к господствующей в этом районе нации (впервые было употреблено применительно к ситуации в Югославии, где сербы уничтожают мусульман, хорваты сербов на территории Хорватии, а затем стало использоваться по отношению к ситуациям в бывшем СССР). Сравним: В Горном Бадахшане хорошо помнят, что взяв под контроль Душанбе, некоторые солдаты правительственных войск занялись этническими чистками, при этом, в первую очередь, уничтожались памирцы [20]; гастролёры из кавказского региона - о преступных группах в Москве и Петербурге, состоящих из «лиц кавказской национальности»; группы повыщенного риска - о наркоманах, гомосексуалистах, проститутках, которые имеют более высокую (чем другие социальные группы) вероятность заразиться СПИДом.

Некоторые виды профессий, эвфемистическое обозначение которых имеет целью повысить престиж этих профессий или скрыть негативное впечатление от обозначаемого «прямым» наименованием рода занятий: оператор машинного доения, оператор на бойне, оператор очистных работ (прежнее ассенизатор, переставшее выполнять свою эвфемистическую функцию); контролер вместо надзиратель, исполнитель о человеке, приводящем в исполнение смертные приговоры (Сравним: палач) и др. Существенную роль в этой группе эвфемизмов играют иноязычные обозначения, например, Профессия Олега гораздо более романтичная и жизненная: он инструктор по случке собак. Олег, правда, обижается, когда его называют "вязальщиком" (от профессионального значения глагола вязать - «случать (животных)»), но ничего не имеет против киносексопатолога [21]. 
Гальперин И.Р. даёт очень схожую классификацию сфер использования эвфемизмов и выделяет четыре группы: религиозная, моральная, медицинская и парламентская [22]. На наш взгляд первые три группы будут входить в личную сферу использования эвфемизмов, которая была обозначена Крысиным Л.П. Последняя же группа подходит под социальную сферу.

Реформатский А.А. в свою очередь выделяет только три группы сфер использования эвфемизмов: религия, смерть и политика [23]. Если внимательно посмотреть на эти классификации то становится понятным, что наиболее полную классификацию дал всё-таки Л.П. Крысин.

\section{Заключение}

Проведя анализ различных источников, можно отметить, что большинство авторов сходятся на мнении, что эвфемизм, прежде всего, предназначен для избежания коммуникативных конфликтов между людьми. Однако, как справедливо отмечает Л.П. Крысин, наша речь со временем приобретает всё более грубые оттенки (на личном плане), что коммуникативный конфликт зачастую случается как результат чьего-то действия, а вовсе не слова. Но не стоит преуменьшать роль языка в нашей жизни. Следуя новой тенденции, наметившейся в мировом развитии, Л.П. Крысин даёт более расширенную классификацию эвфемизмов, нежели другие авторы, в которой раскрывает суть эвфемизма не только в частной сфере нашей жизни, но и в социальной. Именно полнота раскрытия послужила для нас мотивом взять классификацию Л.П. Крысина за основу в этой работе с целью показать растущую роль эвфемизмов в социальной сфере.

\section{Список литературы}

1. Крысин Л.П. Эвфемизмы в современной русской речи / Л.П. Крысин // Русский язык конца 20 столетия (1985 - 1995). - М.: Наука, 1996. - С. 384-385

2. Кёстер-Тома 3. Эвфемизмы / Русистика. - Берлин, 1993, № 2. - С. 26

3. Ларин Б.А. История русского языка и общее языкознание. Учебное 
пособие для факультетов русского языка и литературы педагогических институтов / Б.А. Ларин. - Москва: Просвещение, 1977. - 224 с.

4. Collins-Learner's Dictionary, Collins Harper Publishers, 2000.

5. The Old Nation English Dictionary, USA Publishing, 1999.

6. Longman Dictionary of contemporary English, Longman Publishers, 2000.

7. The American Heritage Dictionary of English language, Houghton Mifflin, 1994.

8. New Webster's dictionary of the English language: college edition, Delhi: Surjeet publ., 1989.

9. Шмелев Д.Н. Эвфемизм / Д.Н. Шмелев // Русский язык: энциклопедия / М.: Советская энциклопедия, 1979. - 402 с.

10. Арапова Н.С. Лингвистический энциклопедический словарь. - М., 1990. -590 c.

11. Варбот Ж.Ж. Табу / Ж.Ж. Варбот. - М.: Русский язык: Энциклопедия, 1997. - C. 81 .

12. СССР. Съезд народных депутатов (6, 1992, Московская область). Шестой Чрезвычайный Съезд народных депутатов СССР. Московская область, 17 марта 1992 года. Документы и материалы. - М., 2019. - 52 с.

13. Архив журнала «Телевидение. Радиовещание» [Электронный ресурс]. URL: http://magzdb.org/j/3534 (дата обращения: 26.08.2021)

14. Разгон Л.Э. Непридуманное: Повесть в рассказах / Лев Разгон. - М.: Книга, 1989. - 285 с.

15. Сахаров А.Д.. Воспоминания: В 2 т. / Андрей Сахаров. - М.: Права человека, 1996.

16. Архив журнала «Радио» [Электронный ресурс]. URL: http://archive.radio.ru (дата обращения: 26.08.2021)

17. Балдаев Д.С. Словарь тюремно-лагерно-блатного жаргона: Речевой и графический портрет современной тюрьмы. Одинцово: Края Москвы, 1992. C. 314 
18. Совершенно секретно, 1992, №4

19. Московские новости. Из постановлений Политбюро ЦК КПСС, 14.02.1992.

20. Независимая газета, 05.07.1993.

21. Московский комсомолец, 08.02.1992.

22. Гальперин И.Р. Очерки по стилистике английского языка / Москва: Изд-во литература на иностранном языке, 1958. - 459 с.

23. Реформатский А.А. Введение в языковедение: Учебник для студентов филологических специальностей высших педагогических учебных заведений / А.А. Реформатский. - М.: Аспект Пресс, 2001. - С. 104-105. 


\title{
ГЛАВА IV.
}

\section{АКТУАЛЬНЫЕ ПРОБЛЕМЫ НЕПЕРЕВОДИМОСТИ}

\author{
Фесюкова Ирена \\ Центр языковой подготовки \\ Университет Яна Евангелиста Пуркине
}

Аннотация: Цель данной работы - представить различные способы решения проблемы непереводимости с целью помочь переводчику выбрать правильный вариант перевода. В работе рассматриваются характерные причины непереводимости лексических и грамматических конструкций, а также высказываются предложения по устранению проблем, возникших в процессе перевода. Кроме теоретического описания отдельных явлений непереводимости уделяется внимание изучению работ российских, чешских и других исследователей по данной теме.

Ключевые слова: лексическая единица, эквивалент, перевод реалий, имя собственное, прозвище, лексический вариант, фразеологизм, язык оригинала, язык перевода.

\section{CURRENT PROBLEMS OF UNTRANSLATABILITY}

Fesjukova Irena

\begin{abstract}
The purpose of this work is to present various ways to solve the problems of untranslatability in order to help the translator choose the correct translation option. The paper examines the most characteristic reasons for the untranslatability of lexical and grammatical constructions, and also develops proposals for eliminating problems that have arisen in the translation process. In
\end{abstract}


addition to the theoretical description of individual phenomena of untranslatability, attention is paid to the study of the works of Russian, Czech and other researchers on this topic.

Key words: lexical unit, equivalent, translation of realities, proper name, nickname, lexical variant, phraseological unit, original language, target language.

Основной задачей переводчика, работающего над текстом, является достижение полноценного перевода. Это требование применимо как к переводу художественной литературы, так и к переводу научных трудов, технических инструкций или деловых документов. Переводчик должен помнить, что обязательным условием для всех переводимых произведений является эстетика языка, что каждое произведение художественной, научной литературы или публицистики является результатом работы автора, мастерски владеющего стилем и лингвистическими средствами родного языка.

В отдельных случаях автор может отклоняться от привычных языковых норм, используя диалектизмы, профессионализмы, архаизмы или терминологию из разных областей знаний, чтобы приблизить читателей к эпохе, социальной среде, поведению героев произведения. Используя такие отклонения, автор ориентируется на нормы языка, на фоне которых отклонения выделяются ярче, создается определенный стилистический контраст. Стремления воспроизводить текст дословно могут вести к непонятности перевода и тяжести его восприятия, поэтому переводчик должен хорошо понимать оригинал текста и виртуозно владеть языками оригинала и перевода. Полноценность и адекватность перевода очень важна, так как она делает возможной передачу всех стилистических особенностей оригинального творчества автора.

Передать контраст было бы невозможным без существования колорита и совершенства общенародного языка. Полноценность языка является условием понимания точности и подлинности в тех случаях, когда оригинал не содержит отклонений от языковой нормы и в том случае, когда такие отступления имеют место. 


\section{1. Проблематика лексической передачи}

\section{1. Перевод слова как лексической единицы}

В процессе перевода переводчик выбирает из словарного состава языка перевода слова наиболее подходящие к оригинальному произведению по смыслу и взаимосвязи. Иногда он может создавать новые слова при помощи морфологических и лексических элементов. Это делается в случаях передачи авторских неологизмов. Лексические возможности переводчика зависят от словарного состава языка перевода. В случае, если в языке перевода нет точного эквивалента слова языка оригинала, переводчик всегда может воспользоваться описательным переводом. Говоря о значении слов текста оригинала и перевода, нельзя забывать о контексте произведения, который необходимо рассматривать как:

- ближний контекст - предложение, состоящее из слов, отражающих слова подлинника;

- более широкий контекст, состоящий из предложений, абзацев или глав.

Контекст является одним из важнейших аспектов при отборе необходимых слов в процессе перевода. Словарный состав языка нужно рассматривать как систему, в которой отдельные элементы тесно связаны между собой смысловыми и стилистическими отношениями, и которые, в свою очередь, не позволяют в процессе перевода использовать ближайший словарный эквивалент к слову текста оригинала.

Если переводчик обязан выбирать из нескольких вариантов, возможна следующая ситуация:

- в языке перевода не существует словарного эквивалента слова оригинального произведения;

- эквивалент языка перевода покрывает только частично значение иноязычного слова; 
- если в оригинальном тексте слово многозначное, то его эквивалентом в языке перевода является слово, передающее в большей или меньшей степени его смысл.

Редким явлением можно считать тот случай, когда однозначное слово оригинала имеет свой эквивалент в языке перевода. Практика показывает, что такое возможно только при переводе терминов.

\section{2. Безэквивалентная лексика, ложные эквиваленты}

Полное отсутствие эквивалента слова считается довольно редким явлением. Проблема возникает тогда, когда в тексте оригинала выступают предметы или понятия, характерные для языка перевода, что, соответственно, вызывает проблемы в процессе перевода. Рассматривая проблематику слов, обозначающих действия, поступки, чувства, эмоции или распространённые явления, вещи, можно отметить, что они практически не вызывают трудностей.

В прошлом определённую проблему представлял перевод научных терминов из области медицины, философии, политики и т.д., поскольку эти термины в одних языках уже существовали, а в других ещё нет. Сомнения у переводчиков вызывала дословная передача иноязычных слов. Однако позже эти слова нашли свои эквиваленты. В советское время в русском языке возникло много слов, не имевших эквивалентов в западноевропейских языках. Такие слова необходимо было переводить при помощи расширительно-описательного перевода и принимать во внимание контекст переводимого текста.

Примерами могут служить такие слова как, «закономерность», «идейность», «партийность». Слову «закономерность» в немецком языке служит эквивалентом слово «Gesetzmäßigkeit» [1. с. 134 - 164], во французском языке присутствуют только частичные эквиваленты «loi», «conformité à la loi» или «régularité». Слово «идейность» в немецком языке имеет только частичный эквивалент «Ideengehalt», что можно перевести как «идейное содержание» или «Ideenreichtum», что можно перевести как «идейное богатство». 
Отсутствие точных эквивалентов в области терминов не означает, что они навсегда останутся непереводимыми. Словарный состав языков постоянно развивается и изменяется в соответствии с развитием и изменением всех сфер человеческой деятельности. Однако необходимо заметить, что слова, которые являются названиями обычных предметов или явлений и не имеют своего эквивалента, как правило, не найдут его и в будущем. В зависимости от контекста их значение может уточняться. Поэтому можно сказать, что проблема переводимости существует в специально-терминологическом, обиходно-бытовом процессе перевода и требует от переводчика уделения внимания речевому стилю и контексту оригинала. Проблема может возникнуть при переводе слова, имеющего несколько значений. В таком случае в переводе необходимо использовать разные слова по значению, отвечающие контексту. Например, английское слово «estate» можно переводить как «состояние», «материальные средства» или же как «имение», «поместье», «имущество». Иногда выбор эквивалента может быть трудным из-за того, что значения слов совмещаются в контексте подлинника. Говоря о полном отсутствии эквивалентов, нужно обратить внимание и на ложные эквиваленты. Под термином ложный эквивалент подразумевается слово, которое частично или полностью совпадает по графической или звуковой форме с иноязычным словом. Например [1. с. 127 - 195]:

- немецкое der Dramaturg (режисёр или заведующий репертуаром театра) и русское драматург (автор драматических произведений или автор, пишущий для театра);

- немецкое der Akademiker (человек с высшим образованием, студент, преподаватель высшей школы) и русское значение слова академик (член академии наук);

- французское ignerer (не знать) и русское значение слова игнорировать (сознательно не обращать внимание); 
- английское pathos (трагизм, грусть, печаль) и русское значение слова nафос (страстное воодушевление, эмоциональный подъём);

- английское regular (точный, правильный, равномерный, верный, справедливый, соответствующий) и русское слово регулярный (точный, правильный, равномерный). В русском языке слово используется только в первых трёх значениях.

В процессе перевода ложные эквиваленты являются серьёзной проблемой и могут доставлять определенные трудности. Поэтому следует обращать внимание на то, чтобы ложные эквиваленты не приводили к смысловому или стилистическому изменению текста оригинала. Переводчику необходимо помнить, что формальное сходство аспектов в языках оригинала и перевода является обманчивым.

\section{3. Проблематика перевода реалий}

Проблематика перевода слов, обозначающих реалии, представляет значительный интерес, поскольку речь здесь идёт о понятиях и вещах, специфичных для определенного народа и государства. Роль реалий в языке, их частота употребления, бытовой характер и значимость содержания могут носить отличительный характер, причём реалии стилистически могут не выделяться и не иметь терминологической окраски.

Переводчику необходимо знать содержание подлинника для правильного перевода, обозначения вещей и образов, о которых говорится в оригинале текста, и которые каким-то образом связаны с реалиями. Текст оригинала даёт переводчику ключ к правильному пониманию действительности, выраженной в тексте оригинала, к адекватному переводу. Он не должен ограничиваться только данными, содержащимися в тексте подлинника, и руководствоваться значением отдельных слов, а наоборот, должен помнить, что словосочетания могут приобретать иное значение. В результате невнимательности переводчика к данному факту могут возникнуть смысловые ошибки. Фактически существуют три способа перевода слов, обозначающих специфические реалии. 
Во-первых, это полная или частичная транслитерация, то есть прямое воспроизведение графической формы слова-реалии или его корня. Нужно отметить, что фонетические и графические системы языков отличаются, и поэтому передача формы слова языка оригинала на язык перевода будет всегда приблизительной. Примером транслитерации могут служить слова:

- skateboarding - скейтбординг;

- $\quad$ Dorset - Дорсет;

- Campbell - Кэмпбелл;

- deescalation - деэскалация;

- Columbia - Колумбия;

- $\quad$ absurdist - абсурдист;

- tomahawk - томагавк;

- canoe - каноэ [3. с. 59-98].

Транслитерация часто используется при переводе названий в сфере общественно-политической жизни и быта. К ним относятся: названия учреждений, обращение к собеседнику или должностному лицу, которые существуют только в данной стране. Примером являются такие слова, как пэр, мэр, ландлорд, эсквайр, акр, морген, фиакр, консьерж, мисс, сэр [4. с. 127-198].

Каждое слово может быть переведено на другой язык, например, при помощи описательного перевода. Специфичность транслитерации состоит в том, что она даёт возможность сохранить лексическую краткость словосочетания, привычную в языке оригинала, и в то же время обратить внимание на специфическое положение вещей или явлений, не имеющих точного эквивалента в языке перевода. Переводчик может отвергнуть использование транслитерации в случае, если не считает нужным специально подчёркивать специфичность называемой вещи или явления в переводе. Излишнее использование транслитерации может привести к засорению языка и к потере смысла текста перевода. Авторы часто используют транслитерацию, когда в своих произведениях описывают жизнь или быт народа. 
Таким образом, они стараются подчеркнуть или отличить вещь или явление, специфичное для другой культуры, хотя оно могло быть названо при помощи лексического перевода на родном языке автора. В случае первого или редкого переноса транслитерируемого слова в языке перевода большую роль играет контекст, но иногда необходимым является и комментарий. Транслитерация используется в переводе в довольно широкой области.

Во-вторых, это создание новых слов, сложных словосочетаний с целью назвать предметы. Причём в создании слов принимают участие морфологические элементы, характерные для языка перевода. Данный способ встречается реже, чем транслитерация. Примером такого способа перевода с полной образно-морфологической формой может быть английское слово skyscraper - небоскрёб или Bundeshaus - здание бундестага. В русском языке этим способом были образованы сложные существительные, которые служат как названия реалий, вошедших в русский быт вместе с явлениями и предметами, названиями которых они являются. Также это касается технических реалий, например: паровоз, пароход, водопровод, громкоговоритель, пылесос. Нужно отметить, что такие слова возникли в общенародном языке, то есть они не связанны с переводом. Сравнение состава и строения данных лексических единиц и их эквивалентов в других языках говорит о том, что они были образованы самостоятельно. Например, русское слово пароход, на английском языке - steamboat, на французском - bateau à vapeur, на немецком - Dampfer, Dampfschiff или паровоз, по французски locomotive, по английски - steam engine.

В-третьих, это приблизительный перевод, который уточняется, принимая во внимание контекст подлинника. Приблизительный перевод в данном случае может граничить с описанием. Это значит, что для перевода используются слова исходного языка, обозначающие что-то близкое по значению и функционированию, но не абсолютно одинаковое. Примеры таких слов встречались, прежде всего, в переводах произведений XIX века. Например:

- извозчик вместо фиакр; 
- швейцар или привратник вместо консьерж;

- стряпчий вместо клерк;

- будочник вместо полицейский комиссар [5. с. 145-168].

Иноязычные обращения, например, французские monsieur и madame переводились как господин и госпожа или как мсье и мадам, английские sir и miss переводились как сударь и сударыня.

О данном виде перевода можно сказать, что он передаёт бытовую окраску слова из исходного языка и может придавать русифицирующий оттенок или же, наоборот, в переводимое слово не вносит новых черт. В таком переводе слово может потерять свой специфический колорит. Минусом данного вида перевода является потеря вещественной специфики слова, а плюсом является доступность контекста в переводе.

Необходимо подчеркнуть, что слово, которое выражает связь с фактами, специфическими для жизни страны, на язык которой текст переводится, не может быть полноценным средством передачи реального понятия из жизни страны, с языка которой делается перевод.

\section{4. Лексический вариант в процессе перевода}

«Огромное большинство слов всякого языка более или менее многозначно. В связи с этим стоит и множественность словарных соответствий как для многозначного, так и для однозначного слова подлинника в других языках - соответствий, используемых в переводах в зависимости от контекста. Но и независимо от этого даже слово с относительно ограниченным числом значений или слово, употреблённое в контексте в одном вполне определённом значении, может вызвать при переводе несколько вариантов» [6. с. 148]. Перевод никогда не должен ограничиваться выбором эквивалентов, присутствующих в словарях, потому что он может соприкасаться со словом или словосочетанием, значение которого словарь не предусматривает.

Интересной является роль синонимических средств, о которых Б.В. Томашевский в статье «Язык писателя» говорит, что они имеют большое 
значение для перевода, как средство, которое своеобразно применяется в зависимости от конкретных языковых ситуаций. То есть слова, словарный смысл которых далёк друг от друга, могут в определённых контекстуальных ситуациях заменять друг друга.

Под термином лексические варианты необходимо понимать часть параллельных и соотносительных средств, которые в языке используются для выражения содержания и являются предметом стилистики. Причём лексический вариант ограничен рамками синтаксической функции слова и грамматической категории.

\section{5. Проблематика перевода имён собственных и прозвищ}

Имена собственные из области культуры, географии, истории, названия мест и прозвища имеют свою семантику, поэтому при их передаче переводчик может использовать как перевод, так и транслитерацию. Традиционно самые известные географические названия передаются при помощи именно транслитерации. Например:

- $\quad$ Mont Blanc - Монблан;

- $\quad$ Dent du Midi - Дан дю Миди;

- Jungfrau - Юнгфрау [7. с. 148 - 169].

Менее известные имена собственные такие, как названия улиц, зданий или местностей, часто передаются при помощи перевода, например:

- Boulevard des Italiens - Итальянский бульвар;

- Boulevard Sévastopol - Севастопольский бульвар;

- Champs Elysées - Елисейские поля [8. с. 148 - 169].

Однако здесь нужно отметить, что в этой традиции существует целый ряд отклонений, например:

- Krkonoše, на русский язык переводятся как Исполиновы горы, а на немецкий как Riesengebirge;

- Unter den Linden - Унтер ден Линден;

- $\quad$ Rue de la Paix - Рю де ла Пэ;

- Pont Neuf - Понт Нёф или переводится как Новый мост [9. с. 148-169]. 
Прозвища исторических личностей, по традиции, принято переводить. Например, Карл Великий, Филипп Красивый, Мария Кровавая. Названия газет, наоборот, принято транслитерировать, хотя и здесь присутствует семантика. Например: Юманите, Дейли Уоркер, Нью Йорк Таймс. Транслитерация в данном случае показывает связь имён собственных с определённой страной.

Можно сказать, что выбор между переводом и транслитерацией при передаче имён собственных, сохранивших свою семантику, производится традиционно. Переводчик должен принимать во внимание уже установившуюся традицию при передаче имён собственных или прозвищ, которые являются вымышленными. Однако в таких случаях чаще всего встречаются колебания и отступления от традиции.

Имена собственные, не сохранившие или не имеющие семантики в современном языке, передаются при помощи транслитерации. Причём они могут быть переведены так, чтобы лишний раз подчеркнуть своё иноязычное происхождение, например: Лиз, Лизетт, Луиз, Анетт или же, наоборот, они переводятся так, чтобы приспособиться к языковой норме русского языка: Лиза, Лизетта, Луиза, Анна. Добавлением окончания женского рода в русском языке достигается эффект ослабления иноязычного характера слов.

При передаче имён собственных большой интерес представляет вопрос их фонетической формы и написания. Причём, чем больше отличаются фонетические системы исходного языка и языка перевода, тем острее дискуссия. Транслитерация используется при существовании общей системы алфавита исходного языка и языка перевода. Примером могут служить западноевропейские, германские или романские языки. Что касается русского языка, то здесь существует традиция передачи звуковой формы иностранных имён собственных. Поскольку присутствуют различия между русским и западноевропейскими языками, можно говорить о частичном воспроизведении имени собственного, которое является компромиссом между его написанием и звучанием. Переводчик обязан придерживаться традиционных правил в 
переводе, связанных с названием рек, городов, исторических личностей или собственных имён. В таком случае звучание выше приведенных названий отходит на второй план. Например:

- Пишем Гамбург вместо Хамбург;

- Лейпциг вместо Лайпциг;

- Париж вместо Пари;

- Рим вместо Рома [10. с. 148 - 169].

В русском написании существуют случаи фонетически близкие по форме иностранным именам, например: Шиллер, Байрон, Данте, Мекленбург, Бранденбург.

Переводчик должен придерживаться традиционных правил, поскольку своеволие переводчика может привести к трудностям восприятия текста и полному непониманию перевода. Он может только переделывать фамилии вымышленных лиц или редко используемые имена.

\section{6. Проблематика перевода фразеологизмов}

Проблематика передачи фразеологизмов представляет интерес как для практики, так и для теории перевода. Теория перевода изучает, прежде всего, отличия между стилистическими и смысловыми функциями, которые фразеологизмы выполняют в разных языках.

Фразеологические единицы в русском языке классифицировали многие учёные. Самой удачной является классификация академика В.В. Виноградова, который выделил три основных вида фразеологизмов [11, с. 58 - 79]:

- фразеологические сращения или идиомы, например: kick the bucket умереть, протянуть ноги; at bay - в безвыходном положении; be at smb.'s beck and call - быть всегда готовым к услугам; быть на побегушках; to rain cats and $\operatorname{dogs}$ - лить как из ведра (о дожде); be all thumbs - быть неловким, неуклюжим; Kilkenny cats - смертельные враги;

- фразеологические единства, например: to spill the beans - выдать секрет; to burn bridges - сжигать мосты; to have other fish to fry - иметь дела 
поважнее; to throw dust into smb.'s eyes - заговаривать зубы; to burn one's fingers - обжечься на чем-либо; to throw mud at smb. - поливать грязью; to be narrow in the shoulders - не понимать шуток; to paint the devil blacker than he is - сгущать краски; to put a spoke in smb.'s wheel - вставлять палки в колеса ; to hold one's cards close to one's chest - держать что-либо в секрете, держать язык за зубами;

- фразеологические или устойчивые сочетания, например: a bosom friend - закадычный друг, a pitched battle - ожесточенная схватка, (to have) a narrow escape - спастись чудом, to frown one's eyebrows - насупить брови, Adam's apple - адамово яблоко, a Sisyfean labor - Сизифов труд, rack one's brains - ломать голову, to pay attention to smb. - обратить на кого-либо внимание.

Остальные сочетания он называл свободными. Фразеологические сращения и единства имеют разговорную окраску, иногда фамилиарно-бытовой оттенок. Одной из главных задач переводчика является сохранение и передача этой окраски в переводе. При этом главным требованием, которое предъявляют теоретики перевода к практикам, является перевод фразеологизма исходного языка при помощи фразеологизма в языке перевода. Переводя фразеологизмы, переводчик должен помнить о том, что полноценный перевод фразеологизма зависит, главным образом, от отношений между единицами исходного языка и языка перевода.

С точки зрения теории перевода фразеологических единиц можно говорить о следующих приёмах:

- фразеологизм исходного языка имеет в языке перевода соответствие, которое не зависит от контекста, то есть фразеологизм исходного языка равен фразеологизму в языке перевода, и в таком случае перевод осуществляется при помощи эквивалента;

- фразеологизм исходного языка можно перевести при помощи соответствия, которое более или менее отступает от полноценного перевода, и в таком случае перевод осуществляется при помощи аналога; 
- фразеологизм исходного языка не имеет в языке перевода ни эквивалентов, ни аналогов. В таком случае перевод осуществляется при помощи нефразеологических средств.

Поэтому перевод фразеологизмов принято делить на фразеологический и нефразеологический. Фразеологический перевод рекомендуется использовать в процессе перевода устойчивых единиц, которые имеют большую степень близости. В данном случае переводчик может использовать как полные эквиваленты, так и приблизительные соответствия.

Фразеологическим эквивалентом называют фразеологизм, который на языке перевода должен иметь такое же смысловое и стилистическое содержание, эмоционально-экспрессивную окраску, метафоричность, лексико-грамматические показатели, компонентный состав, принадлежать к такой же грамматической категории, что и фразеологизм исходного языка. Очень важным является скрытие национального колорита. Такие фразеологизмы часто встречаются в интернациональной фразеологии, потому что они имеют одинаковый источник происхождения, в большинстве случаев греческий или латинский языки, а также Библию. Примерами таких фразеологизмов могут служить: вложить меч в ножны; поднять меч; яблоко раздора; до греческих календ; заколдованный круг; первый среди равных; человек человеку волк; третьего не дано; ждать как манны небесной; Содом и Гоморра; умывать руки [12. с. 36-45].

Неполный фразеологический эквивалент - это единица языка перевода, которая является эквивалентом фразеологизма, переводимого с исходного языка. Однако она не является полным эквивалентом, поскольку имеет отличительные значения от фразеологизма на исходном языке. Например [13. c. 47-58]:

- избиение младенцев является частичным эквивалентом английскому the massacre of the innocents, 
- немецкое dem Feinde den Rücken и французское montrer le dos à l'enemi являются частичными эквивалентами русского показать спину.

Частичные эквиваленты встречаются довольно редко, поскольку многозначность является для фразеологии не характерной.

Относительный фразеологический эквивалент - это фразеологическая единица, которая отличается от абсолютного эквивалента тем, что в ней находятся синонимичные компоненты, присутствуют изменения формы или синтаксического построения, но её семантика полностью отвечает фразеологической единице исходного языка. Небольшие отличия могут находиться в синтаксической или лексической области. Например [14. с. 23-36]:

- немецкое da lachen ja die Hühner звучит «да это же курам на смех!», хотя русским эквивалентом является курам на смех;

- показать спину - английское turn one's back или французское tourner le dos переводится как повернуть спину;

- держать нос по ветру на английском trim one's sails to the wind, на французском aller le nez au vent, однако на немецком den Mantel nach dem Wind hängen;

- на чешском - Znám ho jako své boty, на польском - jak swoje pięć palców, на немецком и французском уже говорится о кармане - kennen wie seine Westentasche и connaître comme sa poche, на русском - знать как свои пять пальиев;

- на чешском - jako by mu z oka vypadl или podobný jako vejce vejci, на французском - ils se ressemblent comme deux gouttes d'eau, на русском - они похожи как две капли воды, на английском - like two pears, на польском - jota w jotę или kubek w kubek tak sam.

Фразеологический аналог - это фразеологический эквивалент, имеющий другую метафорическую основу, то есть это замена образа. Например, родиться в рубашке, у французов être né coiffé - «причёска», у англичан be born with a silver spoon in one's mouth - серебрянная ложка. 
Различаются близкие образы, например, гром среди ясного неба и немецкое Blitz aus heiterem Himmel, или образы далёкие, например, в тихом омуте черти водятся и немецкое stillt wasser sind tief, английское still waters run deep или французское il n'est pire eau que 1'eau qui dort. Однако образы фразеологических аналогов могут быть совершенно не похожими друг на друга, и в то же время быть эквивалентами друг другу в переводе, например, русское когда рак на горе свиснет и рыба запоёт, немецкое wenn die Hunde mit dem Schwanz bellen, английское when the moon turns green cheese.

Индивидуальные эквиваленты - это такие фразеологические единицы, которые придумал переводчик, поскольку не нашёл в языке перевода полного соответствия единице исходного языка.

Нефразеологический перевод предлагает при воспроизведении фразеологических единиц использовать лексические средства. Переводчики его употребляют в случаях, когда, по их мнению, нельзя использовать фразеологические средства. В таком переводе всегда присутствуют некоторые потери, то есть он не является полноценным, поэтому переводчики стараются пользоваться им как можно реже.

Лексический перевод принято использовать в случаях, когда понятие в исходном языке выражено при помощи фразеологической единицы, а в языке перевода выступает как слово или словосочетание. Примером могут служить английские глаголы, которые являются словосочетанием, но переводятся при помощи одного слова [15. с. 13-27]: put on fire - зажечь, catch fire - зажечься, set fire to something - поджечь. Переводчик, используя лексический перевод, при переводе фразеологизма с исходного языка должен стараться приблизиться к фразеологизму в языке перевода или хотя бы стремиться к передаче его отдельных элементов.

Калькирование или дословный перевод может быть использовано только в случае присутствия мотивированности значения целого фразеологизма его отдельными частями. Такой вид перевода чаще всего применяется для перевода 
образных фразеологизмов, которые сохранили внутреннюю форму исходного языка. Переводчики обычно используют дословный перевод, когда в языке перевода существует эквивалент фразеологизма исходного языка, однако его использование может вести к потере колорита.

Описательный перевод часто является объяснением смысла фразеологической единицы, а не её переводом. Однако и здесь переводчик должен стремиться к метафоричности и передаче коннотации, стилистической окраски и экспрессии фразеологизма в исходном языке.

Контекстуальный перевод фактически является растворением фразеологизма в контексте. Переводчики используют контекстуальный перевод при недостатке эквивалентов фразеологизма в языке перевода. Такой вид перевода иногда используют даже в случаях, когда в языке перевода существует эквивалент или аналог.

Выборочный перевод - это перевод словосочетаний при помощи фразеологизмов. Например, французская идиома déferrer des quatres pieds переводится не только при помощи фразеологизмов поставить в тупик, припереть к стенке, но и глаголом озадачить. Поскольку существует довольно большое количество возможностей перевода, переводчик должен принимать во внимание колорит и стиль фразеологизма. Например, глагол умереть имеет следующие фразеологизмы-синонимы - уйти в лучший мир, испустить дух, уснуть вечным сном, дать дуба, отдать концы или сыграть в ящик.

\section{2. Проблематика грамматической передачи}

Кроме выполнения указанных выше задач переводчик должен помнить о том, что выбранные им слова, сокращения, расширения, добавления текста в процессе перевода зависят от грамматических категорий и синтаксических функций.

\section{1. Грамматическое совпадение в подлиннике и переводе}

Грамматические формы языка всегда взаимосвязаны с правилами его развития и отличаются от грамматических форм других языков, хотя в 
отдельных случаях между языками может существовать некоторое сходство. Данные факты являются одной из главных причин морфологических и синтаксических трудностей, возникающих в процессе перевода.

Целью перевода с точки зрения грамматики является передача мысли грамматической формы исходного языка, которая в языке перевода выражается другими грамматическими средствами. С точки зрения стилистики при необходимости переводчик может целиком или частично воспроизводить формы грамматических функций исходного языка в языке перевода. Речь идёт о специфичности грамматических форм исходного языка: краткость, параллельное построение словосочетаний, предложений и частое использование отдельных частей речи. Для воспроизведения данных грамматических форм переводчик может использовать аналогичные средства языка перевода.

Существуют грамматические особенности, которые создают проблемы при изучении языков, но с точки зрения перевода они не представляют для переводчика трудностей, поскольку существуют правила и методы их передачи. К этой категории можно отнести сочетания прямых дополнений с инфинитивом в германских и романских языках, например [16. с.149-198]:

- Je le vois venir - Я вижу, как он идёт;

- Ich sah ihn arbeiten - Я видел, как он работал;

- I expected the travellers to be here by this time - Я рассчитывал, что путешественники к этому времени будут здесь.

Такие сочетания принято переводить при помощи сложноподчинённых предложений, в которых роль подлежащего придаточного предложения выполняет имя существительное, соответствующее по смыслу прямому дополнению в исходном языке.

К этой же категории можно отнести сочетания глаголов scheinen, sember, to seem c инфинитивом, которые принято переводить при помощи предложения, где в роли сказуемого выступает глагол, имеющий значение 
инфинитива, в то время как спрягаемой части сказуемого исходного языка отвечают вводные слова или наречия. Например [17. с.149 - 198]:

- Diese Tätigkeit scheint ihm zu gefallen - Эта деятельность, по-видимому, нравится ему;

- $\quad$ Il sembre être content - Он, кажется, доволен.

Следующим примером могут служить бессоюзные определительные придаточные предложения, существующие в английском языке, например, the books I have been reading, которые принято переводить придаточным определительным предложением или причастными оборотами, то есть: книги, прочитанные мною.

Грамматическое перестраивание словосочетания в процессе перевода характерно для данных языковых особенностей. Однако нужно оговорить, что количество этих особенностей в процессе перевода является ограниченным, и хотя передача их может казаться единообразной, всё-таки о существовании единого метода перевода говорить нельзя. Переводчик, делая выбор из нескольких вариантов, должен принимать во внимание жанр и стиль текста, который он переводит. Число возможных переводов зависит, прежде всего, от контекстуальных условий. Принимая во внимание данные факты, можно сказать, что переводчик может отказаться от односторонности перевода.

Общая теория перевода, главным образом, занимается вопросами проблематики и обобщением трудностей, которые проявляются при исследовании грамматических отношений языков. Проблематика грамматических форм, специфичных для исследуемых языков, привлекает внимание учёных. Возможность обобщения аспектов перевода возникла при исследовании родственных языков и их общих элементов, которые, в свою очередь, отличают их от других языков. Переводчик должен помнить о специфическом и узком характере элементов родственных языков и в процессе перевода использовать лексические или синтаксические черты отдельных языков по своему усмотрению. 
Теоретики перевода пришли к выводу, что точный перевод с точки зрения формально-грамматических категорий часто не является возможным, поскольку не соответствует нормам стилистики и литературному языку перевода. Встречаются случаи совпадения порядка слов, их чисел, грамматических и лексических категорий и значений как в исходном языке, так и в языке перевода. Причиной грамматических отклонений от текста исходного языка может быть необходимость передачи смысла лексических и стилистических норм языка перевода. Для правильного и точного перевода характерно изменение грамматических категорий слов в процессе перевода, добавление и перестановка слов в рамках одного предложения. Изменения грамматических категорий являются основой для решения более сложных вопросов, способствующих устранению трудностей в переводе.

Нужно отметить, что для перевода является характерным, и в большинстве случаев необходимым, отказ переводчика от грамматической точности перевода.

\section{2. Расхождения между языком оригинала и языком перевода}

Во-первых, это случаи, когда в исходном языке существует элемент, не имеющий формально-грамматического соответствия в языке перевода. Например, в русском языке полностью отсутствует категория артикля, сложные формы прошедшего времени, которые являются характерными для германских и романских языков.

Во-вторых, это случаи, когда в языке перевода присутствуют элементы, которые не имеют формального соответствия в исходном языке, причём они часто присутствуют в переводе. В русском языке к ним относится флективная система, форма глагольного вида, причастия прошедшего времени действительного залога и причастия настоящего времени страдательного залога. Данные категории отсутствуют в германских и романских языках.

B-третьих, это случаи, когда в исходном языке, как и в языке перевода, существуют грамматические элементы, которые имеют разные функции. 


\section{3. Грамматический элемент, не имеющий формального} соответствия в языке перевода

Здесь речь пойдет о переводе артикля на русский язык. В начале нужно сказать, что главной функцией как определённого, так и неопределённого артиклей является выражение единственности или множественности предметов, которые они обозначают. Артикли существуют в германских и романских языках, в русском языке они отсутствуют. В переводе это отсутствие проявляется в степени возможности передачи смысла подлинника, на который оказывает влияние разница между определённым и неопределённым артиклем. Артикли в русском языке принято передавать при помощи флективных средств, при этом несоответствие грамматического рода слов не означает существование смысловых разногласий в текстах оригинала и перевода.

Русский язык не воспроизводит артиклей в заглавиях, потому что для последних является характерной краткость. Например [18. с. 169-180], в названии романа «An American Tragedy» подчёркивается тот факт, что эта трагедия является одной из многих, но на русский язык это название переведено как «Американская трагедия». Следующим примером является название французского произведения «Une vie», которое на русский язык было переведено как «Жизнь», хотя стилистически более правильным было бы перевести его как «История одной жизни». Одной из возможностей передачи неопределённого артикля на русский язык является использование лексических добавлений, например: один, какой-то, некий, некоторый. Следующей возможностью является передача с помощью синтаксических средств, то есть передаётся смысловая роль артикля при помощи расстановки членов предложения.

Трудно передать в русском языке разницу между определённым и неопределённым артиклем только с помощью лексических средств, но выразить смысл неопределённого артикля можно благодаря перестановке 
имени существительного в конец предложения. Если подлежащее находится в предложении в позиции за сказуемым, то это указывает на неожиданность действия и неопределённость лица, выступающего в предложении. И наоборот, если постановка слов в подлиннике отвечает всем правилам и языковым нормам, то это указывает на определённость действия. Исследования говорят о том, что самым характерным способом постановки предложения при переводах с немецкого, французского, английского языков является в русском языке предложение, где подлежащее находится вначале, и уже после него следует сказуемое. Примерами синтаксической передачи определённого артикля могут служить следующие предложения [19. с. 169-180]:

- The son was returning with even more success than the community had hoped for... - Сын возвращался на родину, преуспев даже больше, чем от него ждали...;

- The women and children and old men had gone. The greeting was over till the evening. - Женщины, дети и старики ушли. Приветствия кончились - до вечера.

Синтаксические средства русского языка предоставляют несколько способов передачи смысловых оттенков, которые в германских и романских языках выражает именно артикль.

C точки зрения теории перевода можно сказать, что передача грамматических особенностей исходного языка, у которых в языке перевода не существует формального соответствия, производится с помощью синтаксических средств. При этом важно осознать, что для передачи артиклей русский язык использует свободный порядок слов. 


\section{4. Проблематика передачи конструкций с неопределённо-личными} местоимениями

Под термином неопределённо-личные местоимения следует понимать английское one, немецкое man и французское on. Для передачи функции таких местоимений на русский язык необходимо выбрать формально отличные аспекты, потому что в русском языке они не имеют прямого грамматического соответствия.

Первым способом перевода таких местоимений на русский язык является использование глагольного сказуемого в третьем лице множественного числа при отсутствующем подлежащем, например man sagt - говорят. Вторым способом перевода неопределённо-личных местоимений является использование безличных предложений, например, man hörte - было слышно или man stellte fest - было установлено.

Переводческая практика показывает, что существует много других возможностей перевода, которые употребляют переводчики. Примером использования неопределённо-личных местоимений может служить следующее [19. c. $169-180]$ :

- On attend. On se fatigue d'être assis; on se lève. Les articulations s'étirent avec des crissement de bois qui joue et de vieux gonds. L'humidité rouille les hommes comme les fusils, plus lentement mais plus à fond. Et on recommence, autrement, à attendre. - Ждём. Надоедает сидеть; встаёшь. Суставы вытягиваются и потрескивают, как дерево, как старые дверные петли. От сырости люди ржавеют, словно ружья, медленней, но основательней. И сызнова по-другому принимаются ждать.

- On attend toujours, dans l'état de guerre. On est devenu des machines à attendre. Pour le moment c'est la soupe qu'on attend. Après, ce seront les lettres. Mais chaque chose en son temps: lorqu'on en aura fini avec la soupe, on songera aux lettres. Ensuite, on se mettra à attende autre chose. - На войне ждёшь всегда. Превращаешься в машину ожидания. Сейчас мы ждём супа. Потом будем 
ждать писем. Но всему своё время: когда поедим супу, подумаем о письмах. Потом примемся ждать чего-нибудь другого.

Из этого следует, что для перевода на русский язык неопределённоличных местоимений подходят следующие способы:

- во-первых, это использование личного местоимения первого лица множественного числа, то есть «мы»;

- во-вторых, это использование в процессе перевода безличных оборотов;

- в-третьих, это использование местоимения второго лица единственного числа в обобщённо-личном значении.

Нужно отметить, что правильный перевод предложений, содержащих неопределённо-личные местоимения можно осуществить, принимая во внимание только контекст целого переводимого текста.

\section{5. Специфические элементы грамматического строя языка} перевода

Переводчик может использовать особенности грамматики языка перевода, которые не имеют прямого соответствия в исходном языке, а также принимать во внимание контекст. К таким особенностям русского языка относятся использования категорий вида, разнообразия причастных форм и использования уменьшительных суффиксов и суффиксов субъективной оценки.

Категория вида в русском языке является специфическим элементом и используется в переводе с германских и романских языков для передачи значения простых и сложных форм времени. Главной задачей остаётся использование форм вида для получения полноценного перевода русского языка. Форма глагольного вида в русском языке является одним из самых важных средств для выражения форм времени в других языках. Категория вида в русском языке служит для различия тех фактов, которые не разграничены в исходном языке. Человек, переводящий на русский язык, должен выбирать из возможностей, которых не существует в тексте оригинала. Во-первых, это 
случаи, когда из исходного языка необходимо перевести глагол в неспрягаемой форме, то есть в форме инфинитива или герундия. Например [20. с. 169-180]:

- And here I resolved to prepare for a longer journey than all these, having lived a life of infinite variety seventy-two years and learnt sufficiently to know the value of retirement, and the blessing of ending our days in peace. - И здесь, порешив не утомлять себя больше странствованиями, я готовлюсь в более далёкий путь, чем описанные в этой книге, имея за плечами 72 года жизни, полной разнообразия, и научившись ценить уединение и счастье кончать дни свои в покое.

В русском языке существуют формы вида, которых нет в исходных языках. Данный факт создаёт в процессе перевода определённые проблемы, например, при передаче ряда глаголов в форме инфинитива, которые нуждаются в открытии степени длительности, обозначаемого ими действия в процессе перевода, причём глаголы могут находиться в противоречивом отношении.

Одним из видов перевода может служить расчленение предложения, содержащего ряд инфинитивов, на несколько более маленьких. Для раскрытия характера действия в русском языке служит форма вида перевода, который обозначается глаголом исходного языка. Переводчик должен выбирать форму вида перевода, а также обращать внимание на контекст и смысл исходного текста.

Занимательным является разнообразие причастных форм в русском языке и их сравнение с германскими и романскими языками. Система причастий в русском языке состоит из причастных форм прошедшего и настоящего времени, действительного и страдательного залога, совершенного и несовершенного вида. Русская система причастий богаче, чем аналогичные системы других языков. Русское причастие прошедшего времени действительного залога можно использовать, например, для перевода определительного придаточного предложения исходного языка: 
- ... the past of Gorki was the path of the working class which made the revolution possible. - ... прошлое Горького - это путь рабочего класса, сделавший революцию возможной.

Использование уменьшительных суффиксов и суффиксов субъективной оценки в процессе перевода на русский язык, означает увеличение конкретности бытовой ситуации и психологической характеристики, что придаёт яркость впечатлению, которое является отражением действительности исходного текста.

С точки зрения морфологии русский язык по сравнению с другими языками обладает развитой системой суффиксов, которые выражают субъективную оценку и количественную степень. Данные суффиксы связаны с категориями имён существительных и прилагательных. Присутствие этого вида суффиксов в категории имён прилагательных вызывает особый интерес, потому что в западноевропейских языках они в данной категории отсутствуют.

Смысл, который в русском языке словам придают уменьшительные суффиксы и суффиксы субъективной оценки, в западноевропейских языках выражается при помощи специальных лексических элементов, которые могут обозначать размер, например: klein, groß, ein wenig, petit, grand, un peu, little, big, ..., ласкательное отношение пишущего или говорящего к предметам или другим лицам, например: lieb, nett, cher, joli, dear, pretty, ... Такое отношение может и не выражаться, читатели его могут только подразумевать в связи с контекстом.

Русский язык позволяет переводчику в процессе перевода имён существительных, прилагательных и наречий пользоваться своей морфологической особенностью, то есть выражать смысловые оттенки.

Примером могут служить следующие предложения [21. с. 169-180]:

- Elle avait un jupon rouge fort court qui laissait voir des bas de soie blancs avec plus d'un trou, et des souliers mignons de maroquin rouge... - На ней была 
очень короткая красная юбка, позволявшая видеть белые шёлковые чулки, довольно дырявые, и хорошенькие туфельки красного сафьяна....

- Une robe à paillettes, des souliers bleus à paillettes aussi, des fleurs et des galons partout... - Платье с блёстками, голубые туфельки и тоже с блёстками, всюду цветы и шитьё...

- Tout celà, il fallut encore que je le portasse dans des sacs de papier... - Bcë это я опять должен был нести в бумажных мешочках...

Переводческая практика показала, что стандартного подхода к использованию суффиксов в процессе перевода на русский язык не существует. Переводчики их, с одной стороны, правильно используют там, где они в исходном языке не имеют соответствия, а, с другой стороны, их использование иногда может вызывать сомнения, даже когда они имеют в исходном языке соответствие. Правильный выбор использования суффиксов в переводе на русский язык или, наоборот, отказ от их использования устанавливается, во-первых, при помощи соотношения смысловых функций, которые имеет лексический элемент в исходном языке и суффикса в языке перевода, во-вторых, при помощи смысловой и стилистической информации целого предложения, абзаца или текста. Переводчик должен, переводя с русского языка на другие языки, в которых система суффиксов субъективной оценки мало развита или отсутствует совсем, обращать особое внимание на трудности, которые необходимо преодолевать с помощью использования добавочных лексических средств.

3. Использование грамматических элементов, формально совпадающих с элементами языка подлинника, но имеющих другую функцию

Исходный язык и язык перевода имеют в своём распоряжении большое количество формально близких или тождественных грамматических средств, однако стилистические и смысловые функции этих средств могут быть 
абсолютно разными. Поэтому существует опасность того, что внешнее сходство может озадачить переводчика.

Самое правильное решение данной проблемы заключается в применении в процессе перевода формально отличительных от исходного текста элементов, которые контекстуально выполняют функции, соответствующие по смыслу и стилистически исходному тексту. Это значит, что грамматический аспект исходного языка имеет формальное соответствие в языке перевода, однако его функция является специфичной, и грамматический аспект языка перевода, формально отвечающий ему, является неподходящим, и поэтому на его место становится элемент, формально отличающийся, выполняющий специфическую функцию в языке перевода.

\section{1. Различия синтаксических возможностей двух языков}

Флективная система русского языка и свободный порядок слов являются средствами, которые позволяют переводчику использовать большое количество средств в процессе перевода с других языков. Переводчик данные средства использует в случае:

- когда грамматическая особенность исходного языка не имеет формального соответствия в русском языке, или когда определённая грамматическая категория в русском языке не существует. Переводчик должен решить проблему компенсированием смысловыми оттенками, которые он вкладывает в порядок слов в предложении.

- когда точное воспроизведение элементов исходного языка и их последовательности возможно, но из-за этого теряется смысл или же нарушается языковая полноценность. Поэтому переводчики часто вынуждены в процессе перевода заменять грамматические обороты, которые можно переводить дословно, другими, отвечающими нормам литературной речи, или изменять порядок слов для достижения языковой полноценности.

Часто перестройка членов предложения в процессе перевода означает разделение предложения на несколько самостоятельных. Характерным в 
использовании этого средства при переводе на русский язык является то, что его используют в связи с типичными для русского языка синтаксическими конструкциями, которые изменяют синтаксическую линию предложения или делают необходимым его расчленение, например [22. с. 169-180]:

- I had two elder brothers, one of which was lieutenant-colonel to an English regiment of foot in Flanders, formely commanded by the famous Colonel Lockhart, and was killed at the battle near Dunkirk against the Spaniards. - У меня было два старших брата. Один служил во Фландрии, в английском пехотном полку, - том самом, которым командовал знаменитый полковник Локгарт; он дослужился до чина подполковника и был убит в сражении с испанцами под Дюнкирхеном.

Переводчики довольно часто используют приём разбивки предложений, чтобы передать привычность, лёгкость и естественность, звучащие в предложении в исходном языке.

\section{2. Выбор грамматического варианта в процессе перевода}

O грамматических вариантах нужно сказать, что синонимия в них проявляется только в целом. Это значит, что полноценной заменой грамматического варианта может служить только другой грамматический вариант, причём отдельные слова синонимами не являются. Например, синонимами будут придаточное предложение «... человек, который выполнил эту работу» и причастная конструкция «... человек, выполнивший эту работу». Однако глагол «выполнить» и причастие «выполнивший» не являются синонимами. В этом состоит главное отличие грамматической синонимики от системы синонимов в целом.

Грамматические варианты, которые являются средством выражения однородного содержания, бывают неравноценными с точки зрения стилистики. Это значит, что они не всегда могут быть синонимами друг к другу. Выбор грамматического варианта в большей или меньшей степени зависит от контекста, который определяет необходимый смысловой оттенок и в то же время от речевого стиля. 
В процессе перевода необходимость считаться с грамматическими вариантами данного языка и выбирать наиболее правильный проявляется с большей силой, чем при работе с текстом исходного языка. Причиной этого является то, что вариант, формально близкий к исходному языку, часто бывает неуместным или неполноценным с точки зрения стилистики. Поэтому переводчик должен выбирать из других вариантов наиболее подходящий. Например, предложение «Der Dampfkessel wurde in Betrieb gesetzt, ohne daß seine Wände verzinkt wurden» с немецкого языка переводится как - «Котёл вступил в эксплуатацию без того, чтобы стенки его были оцинкованы», а самым правильным переводом является - «Котёл вступил в эксплуатацию с неоцинкованными стенками» [23. с. 169-180].

Проблема возникает, когда в процессе перевода выясняется, что язык перевода имеет в своём распоряжении большее количество грамматических вариантов для передачи содержания исходного текста. Иногда бывает важным обратить внимание именно на глагольный элемент, который активно выражает действие героя произведения. Например, заглавие «L'homme qui rit» - «Человек, который смеётся» или «Der Mann, der shwieg» - «Человек, который молчал». Однако это словосочетание, находящееся в составе распространённого или сложного предложения, лучше переводить с помощью причастного оборота.

Нужно сказать, что переводчики художественной литературы часто предпочитают пользоваться причастными оборотами, хотя это стилистически неоправданно, потому что этот оборот имеет книжную окраску и обладает меньшей мерой живости. Присутствие нескольких причастных оборотов, зависящих друг от друга, в русском предложении вызывают чувство однообразия и нечёткости. Переводчик поэтому должен работать с текстом перевода, соблюдая все правила и нормы работы над исходным текстом.

Грамматические варианты, которые могут использоваться в процессе перевода, также как и грамматические варианты, предназначенные для работы автора над оригинальным текстом, не являются равноценными. Требования, 
предъявляемые к стилю и смыслу исходного текста, а также требования к полноценности языка перевода вынуждают переводчика в зависимости от случая выбирать наиболее правильный грамматический вариант.

Проблематика выбора грамматических вариантов должна рассматриваться в общей теории перевода. Она является одной из основных тем частной теории перевода и объединяет вокруг себя все конкретные проблемы практики перевода. При выборе и использовании грамматических вариантов в процессе перевода является характерным взаимодействие грамматических систем исходного языка и языка перевода.

Обобщая проблематику грамматических вопросов перевода, можно сказать, что:

- при решении грамматических проблем перевода в главной роли выступает единство требований содержания и элементов формы, причём их смысловую роль устанавливает связь с содержанием и требованием языка перевода;

- существует разница в грамматических системах исходного языка и языка перевода. Данный факт делает невозможной формально точную передачу значения грамматических форм, что должно компенсироваться благодаря другим грамматическим и словарным средствам;

- в большом количестве случаев решение вопроса о средствах передачи в более узком контексте не представляется возможным. Поэтому необходимо постоянно помнить о системе языковых средств как об одном целом, а не об отдельных её аспектах, которые сами по себе могут оказаться непереводимыми.

Контекст (узкий и широкий) заставляет переводчика уделять особое внимание связи стиля речи произведения на исходном языке со стилем речи переводного произведения. Поэтому необходимо заниматься стилистическими проблемами, возникающими в процессе перевода. 
Методы решения переводческих проблем, которые возникают из-за разниц в грамматическом строе исходного языка и языка перевода, являются интересными для целого ряда научных дисциплин.

Подводя итоги, можно сказать, что переводчик должен помнить, что его главной задачей является создания полноценного перевода. Переводчик должен помнить об обязательной для всех видов перевода языковой эстетике, а также о том, что каждое произведение является результатом работы человека, который прекрасно владеет языком. Поэтому он должен правильно выбирать и использовать лексические и грамматические средства в процессе перевода.

\section{Список литературы}

1. FESJUKOVÁ Irena. История теории перевода в России с особым учётом к проблематике непереводимости. Olomouc, 2008, 123 s. Diplomová práce. Univerzita Palackého. Vedoucí práce Doc. PhDr. Zdeňka Vychodilová, CSc.

2. KUFNEROVÁ Zlata C. Флорин. Překládání a čeština. Jinočany: $\mathrm{H}+\mathrm{H}$ (H\&H), 1994, 270 s. ISBN 80-857-8714-8.

3. ВАГАПОВА Л.Л., ВАГАПОВ А.С. К проблеме перевода английской безэквивалентной лексики, 2007.

4. ВИНОГРАДОВ В.В. Об основных типах фразеологических единиц в русском языке, Виноградов В.В. Лексикология и лексикография. М., 1986

5. ВЛАХОВ С.С. Флорин. Непереводимое в переводе. Москва: Международные отношения, 1980, 343 с.

6. ПАРШИН А. Теория и практика перевода. 1. Москва, 1985, 310 с.

7. ФЁДОРОВ А.Б. Введение в теорию перевода. 5. Санкт-Петербург: Филология ТРИ, 2002, 416 с. ISBN 5-8465-0019-6. 


\title{
ГЛАВА V.
}

\section{УДК 821.512.145}

\section{ПРОЗА Р. ВАЛЕЕВА В КОНТЕКСТЕ ТАТАРСКОЙ ЛИТЕРАТУРЫ ВТОРОЙ ПОЛОВИНЫ ХХ ВЕКА}

\begin{abstract}
Хайруллина Альфира Салихзяновна к.филол.н., доцент кафедра татарской филологии Елабужского института (филиала) Казанского федерального университета
\end{abstract}

Аннотация: Р. Валеев, пришедший в татарскую литературу как поэт, пробует свои силы в прозе и вскоре его прозаические произведения обретают популярность среди читателей. Автор в своих произведениях ставит ряд жизненных проблем данного времени, но сам однако не дает решение этих вопросов. В данной монографии анализируются серьезные раздумья писателя о жизни, о ее смысле, об обществе, о его состоянии и о его будущем. Книга рекомендуется широкому кругу читателей.

Ключевые слова: татарская литература, деревенская проза, личность, герой, жизнь и смерть.

\section{R. VALEEV'S PROSE IN THE CONTEXT OF TATAR LITERATURE OF THE SECOND HALF OF THE TWENTIETH CENTURY}

\section{Hajrullina Alfira Salihzyanovna}

Abstract: R. Valeev, who came to Tatar literature as a poet, tries his hand at prose and soon his prose works gain popularity among readers. The author in his 
works poses a number of life problems of this time, but he himself, however, does not give a solution to these issues. This monograph analyzes the serious thoughts of the writer about life, about its meaning, about society, about its state, and about its future. The book is recommended for students, teachers and for a wide range of readers.

Key words: Tatar literature, village prose, personality, hero, life and death.

«Как известно, проза является одним из ведущих жанров в литературе. Основные философско-эстетические единицы писателя, присущие его творчеству, можно определить именно по его прозе. Идеи и проблематика текста, композиционное строение текста и художественная амплуа героя - все это опирается на данные категории» - пишет Т.Н.Галиуллин [4, с.151].

Каждый писатель в своих произведениях изображает жизнь. Но как, какими средствами и при помощи каких приемов - это уже зависит от литературных способностей писателя, его восприятия жизненных ситуаций и жизненного опыта. В действительности же, изображая жизнь через призму своего сознания, подчиняясь определенным литературным законам, писателю удается породить новый творческий мир.

Литературное произведение изображает жизнь людей. Человек живет в определенном окружении, в обществе, исходя из этого писатель вынужден изображать период жизни героев, окружение и условия их жизни. Но нельзя думать, что автор прямо переносит в свои произведения реально происходившие события, людей. Лишь только посредством художественного вымысла писателю удается изобразить в своем произведении всю полноту жизни. «Созданное художником, мастером слова художественное произведение является художественной иллюзией, но эта иллюзия...о действительности. Именно эта иллюзия является проявлением самых сокровенных желаний и надежд человека в истории общества. Она вмещает в себя тягу человека к справедливости, свободе и равенству» [3, с. 56]. 
Об основных житейских философских категориях - жизни, ее смысла и бытия задумывались многие ученые, поэты, философы. Дэрдеменд, пользующийся высоким авторитетом среди татарских поэтов, пишет так:

Словно золото в грязи это время, Нә алтын белгә балчык бу замана,

Неужто, кому-то оно еще по нраву? Белалмыий: кемгə тансык бу замана?

В молодости было игриво и свежо, Уенчак, ящь иде ящьлек көнемдә

Ныне же истёрлася в труху! Бүген - карт белгә карчык бу замана!

Профессор Д. Загидуллина дает научную оценку человеческому бытию: «Житье - это главная ступенька в развитии Вселенной. В философии понятие житье имеет две формы: объективную и субъективную. Первая форма - это естественный процесс. А вторая - это жить любя, творя, помогая другим и т.д. Данная форма тесно связана со свободой личности. Если человек перестает думать, рассуждать, творить - это значит, что наступила его смерть».

Разиль Валеев же в своих произведениях ведет серьезные размышления о жизни и смерти, о смысле жизни, течении жизни и ее быстротечности. Давая оценку творчеству писателя, Д. Загидуллина пишет: свобода, воля, независимость, считающиеся основными объектами человеческой жизни, составляют важнейший фундамент творчества писателя.

«Художественная литература помогает в понимании мира и жизни, хотя и не в прямом смысле слова, но участвует в переустройстве общества и жизни: как искусство посредством слова восхищает, оказывает влияние на ум и мышление» [11, с. 7]. Писатель, обрисовывая действительность и жизнь, использует слова, обладающие широкими, в сущности своей ничем не ограниченными возможностями. И это все потому, что многие виды искусства рождают «остановленные» моменты, литература же отображает жизнь во всестороннем развитии. Авторы при помощи слов создают предметы, различные картины и человеческие образы, т.е. своих героев. Читатель же 
вместе с героями произведений радуется их успехам, волнуется, если им грозит опасность, переживает, начинает жить их проблемами.

В современной гуманитарной науке построение личности героя изучается всесторонне, а искусство уже объединяет позиции всех наук. Герой - основной объект изучения искусства. Вследствие того, что литература является наукой «человеческого познания», своеобразное решение проблем личности определяет основное творческое направление каждого писателя. Понимание основы человеческой личности, ее сущности непосредственно находит отражение в его творчестве. По этому поводу в литературоведении высказывается такое мнение: «Концепция человека составляет основу, движущее начало искусства, внутреннюю сущность художественного образа. Вокруг этой основной проблемы концентрируются все другие компоненты искусства» [9, с. 238].

В произведении автор, безусловно, выражает свое отношение к жизненной позиции героя, его ориентации моральных ценностей. Поэтому образ, персонаж и герой формируются как основа концепции и идеи автора. Естественно, данная основа в рамках литературного произведения по воле автора отражает систему взглядов на мир и служит этой системе. Посредством душевных состояний и психологических переживаний героя читатель проникает во внутренний мир автора.

«Воспринимая героев как людей, - писал Г.А. Гуковский, - мы постигаем их одновременно и как некую «идейную сущность»: каждому из читателей подобает ощутить и осознать «не только мое отношение к данному действующему лицу, но и отношение к нему же автора, и, что, пожалуй, важнее всего, мое отношение к отношению автора»») [7, с. 36].

Итак, изучая концепцию героя в творчестве писателя, нельзя оставлять в стороне эстетические и моральные идеалы, особенности того времени, вопросы философских и культурных особенностей писателя. 
Поиски героя являются своеобразной чертой многовековой истории литературы татарского народа. Как известно, такие идеи, как гордость героя, помощь другим, воспитание в герое положительных качеств мы наблюдаем уже в древней письменной литературе.

"По мнению Р.М.Амирханова, татарская литература развивается в двух направлениях: религиозном и мирском. Первое направление изменяется, находясь под влиянием поэтов-суфиев - Ахмада Ясави, Сулеймана Бакыргали, второе же испытывает влияние И.Баласагунлы, А.Югнаки” [12, с. 22].

Восприятие героя, воплотившего в себя моральные нормы и положительные жизненные начинания, были присущи как видным писателям средневековья - Кол Гали, Сайф Сараи, Котб, Мухаммадъяр, так и другим. «И в древней, и в средневековой тюркско-татарской литературе гуманистический взгляд на героя, светское образование, борьба справедливости со злом считались важнейшими вопросами. Свобода личности и сознания, совершенствование нравственных законов также можно считать основными проблемами эстетических учений древности. Традиции таких взглядов можно увидеть и в литературе Восточной Арабии, Средней Азии, Ирана и вообще в прогрессивных начинаниях средневековой философии» - пишет известный литературовед М.Залялиева [10, с. 128].

Безусловно, неразумно будет искать в средневековых произведениях героев, полностью оторванных от традиций Ислама. А все потому, что человеком того периода религиозные понятия не воспринимались как идеология, а жизнь сама постигалась на веру. А «в период Золотой Орды в центр внимания литературы попадает человек, его внутренний мир, поступки, отношения с обществом и природой. Как правило, он - мусульманин, личность, верующая в Аллаха. Но авторы, в первую очередь, обращают внимание не на его верование, а на моральный облик, характер и поступки» [14, с. 35].

Даже после ликвидации татарского государства, письменная литература не прекращает свою существование. Правда, прекращение существования 
Казанского ханства наложило глубокий отпечаток на содержании произведений. Во-первых, “оставшие в живых после разрушительных войн XVI века, лишившись реальной власти и потеряв диктаторские права, татарские “национальные” феодалы вели экономически ослабленное существование. В связи с коренным разрушением инициативного, способного руководить господствующего класса, т.е. высшего слоя общества - феодалов, деятельность народа в духовной сфере весьма ослабла» (авт.) [6, с. 97]. Вторая причина порождена первой - работа, которую должны выполнять мурзы, переходит к муллам и хазрятам, таким образом, интеллектуальная жизнь переходит в руки духовных людей, и как следствие этого, в произведениях начинают преобладать религиозные мотивы.

В XIX веке литература начинает выходить из застоя. Но и это произойдет не за один день, не за один год. «В творчестве Абульманиха Каргалы (1782 после 1883 г.), Шамсутдина Заки (1821-1865), Хибатуллы Салихова (1794-1867) и некоторых других поэтов XIX века господствуют идейно-эстетические принципы, художественные средства, присущие литературе Средневековья (бродячие сюжеты, преобладание условностей, гротекс, ориентация на Восток, насыщенность религиозно-суфийскими идеями и молитвами, замкнутость художественного времени и др.). А с 80-х годов усиливается, особенно в творческой деятельности Мусы Акъегет-заде (1864-1923), Загира Бигиева (1870-1902), Габдрахмана Ильяси (1856-1895), Шакира Мухаммедова (1865-1923), Ризы Фахрутдинова (1858-1936) и других, интерес к реальной жизни татар, доминируют просветительская идеология и реалистические принципы изображения. Литературный язык все более сближается с народным, наблюдаются успешные сдвиги в изучении и освоении художественного опыта русской и западноевропейской литературы» [13, с. 11].

Вооружившись просветительской идеологией, татарская литература XIX века смело и уверенно перешагивает порог XX столетия. «В истории татарской письменной литературы начало XX столетия занимает своеобразное 
место. Хронологически это короткий промежуток времени, ограниченный первым русским переворотом и Октябрьской революцией 1917 года. Начавшийся в татарской литературе во второй половине XIX столетия Ренессанс в начале XX столетия достигает самой высокой точки в истории своего развития. Созревшие его внутренние потенциальные возможности присоединяются к мировому движению литературно-эстетической мысли. Расширение общественного взгляда на мир, рост уровня сознания и усиление национально-осбоводительного движения татарского народа дополнительно ускоряют этот поворот.

Идейное содержание литературы, поставившей в центр национальную тему, заметно расширяется. Силу художественного слова можно увидеть не только в понимании и оценке мира, но и в стремлении проникнуть в трудные для осознания, невидимые глубины (мира), а также в новых жанрах, где внутренние переживания человека нашли художественное оформление» (авт.) [8, c. 3-4].

Пришедшие к власти в октябре 1917 года коммунисты, объявив диктатуру пролетариата, начали смотреть на литературу как на идеологическое орудие. Литературные произведения начинают оцениваться не по доставляемому эстетическому наслаждению, а по степени ответа классовости.

Но литературу 1920-30-х годов нельзя оценивать только с отрицательной стороны. В этот период в литературе идут поиски, несмотря на трудные и даже суровые условия, намечаются дальнейшие пути развития литературы, вырабатывается своеобразная концепция героя.

Остановимся на определении «Своеобразный герой». В 1920 годы в литературоведении преобладает догматическое учение марксизма «Человек совокупность социальных отношений». Данный взгляд приводит к вульгарносоциологическим отклонениям. Эти ошибочные воззрения посредством работ Ф. Переверзева и, особенно, В. Фриче проникли и в татарскую литературу. Как известно, В. Фриче старался изучить развитие художественной литературы в 
тесной связи с социально-экономическим развитием общества. Но он не очень понимал суть таких отношений и не мог их доходчиво объяснить. Человек В.Ф. Переверзева - субъект биолого-социальный.

Поначалу, увлекшись концепциями данных ученых, Г. Нигмати писал: «Требования, поставленные Фриче к производственному жанру, его указания о том, что, не изображая романтические образы, «характеры», давать силу организованного коллектива, даже создавая образ отдельного человека, следует показать его членом отдельного коллектива, представителем класса-строителя, очень уместны и удачны» $[16$, с. 57$]$.

В 1920 годы появилась теория «живого человека», обоснованная В.Ермиловым. Эта теория сыграла большую роль в борьбе с рационалистическим примитивизмом в изображении человека. Но еe сторонники в изображении характера героя предпочитают обращать внимание только на внутренние мотивы. Биологический момент и роль инстинкта преподносятся преувеличенно. Таким образом, психологизм превращается в самоцель.

В 1930 годы литературоведение и критика разрабатывают концепцию героя социалистического реализма. Ярким примером этому являются труды Г. Нигъмати, Г. Гали, Г. Халит. Вопрос зарождения метода соцреализма еще окончательно не решен, хотя такие теоретики, как А.И. Овчаренко [1972] и А.И. Метченко [1975] защищают метод и видят истоки соцреализма в самом литературном процессе.

Критики и писатели в годы Великой Отечественной войны обращают внимание на изображение героического характера солдат, работников тыла. В этот период герои нашей литературы чувствовали свою тесную связь с партией и народом, силу и непобедимость советского строя. В произведениях военного периода основным героем выступает борющееся с фашизмом Отечество. 
«Война отчетливо показала, что в человеке именно соцреализм развивает и формирует все самое лучшее, светлое, гуманное. В то же время эти «вечные», высокие и благородные, истинно человеческие качества и свойства являются глубоко социальными и национальными, присущими всему советскому народу: рабочим, крестьянам, интеллигенции. Особое внимание писатели обращают на исконные, непреходящие черты характера» [16, с. 110].

Война выдавала писателям совершенно незнакомый материал, который требовал кропотливой, но оперативной работы над собой. В первое время давало о себе знать отсутствие опыта в освоении подобного материала, что было свойственно всем жанрам литературы: будь то проза, поэзия, драматургия. О прозе, например, Г. Халит писал:

«Но пока прозу можно рассматривать еще только как первые опыты изображения отдельных черт характера татарских воинов. Вместе с тем, в произведениях, названных маленькими рассказами, татарский солдат еще не поднялся до уровня литературного образа. В большинстве случаев в глаза бросаются фрагменты и образы, свойственные очерку. Правда, было много произведений, где одно отдельное событие и какая-нибудь черта героя изобразились удачно» (авт.) [18, с. 112].

В послевоенные годы в центре внимания критиков и литературоведов стояла проблема положительного героя. Возникло некоторое оживление творческой мысли, робким проявлением которого было начало дискуссии о положительном герое. Это явилось отражением озабоченности части писателей-практиков и критической мысли судьбой литературы соцреализма.

«В литературе послевоенного периода героям войны начали уделять еще больше внимания. Естественно, в литературе этого периода герой изображается очень бойким, смелым. На арену выходят сильные образы, отражающие интеллектуальное, морально-политическое развитие советского народа» $[17$, c. 43$]$. 
Татарская критика и литературоведение положительно воспринимают новый метод и его героя, возникшие за счет отрицания прочих. Творческие методы реализма и романтизма по-разному подверждали художественную концепцию личности. Они, например, по-разному восприняли взаимоотношения личности и общества. Реалистическому восприятию характера человека, его владению собой в общественных условиях противопоставляется романтическая идея независимости личности, его самостоятельный духовный рост.

В разные периоды развития реализма было много написано по проблеме положительного героя. Оставшаяся на протяжении эпох целостной и без изменений концепция героя, подчиняясь внешним обстоятельствам, лишь обретает новые качества. Данный феномен в татарской литературе стал известен под названием «положительный герой». «Все положительные качества, присуще человеку, автор старается воплотить внутри этого образа», пишет И.Нуруллин (авт.) [15, с. 140].

Классовость считается основным качеством характера героя. Как господствующий класс он в себе должен отражать классовые воззрения пролетариата, выполнять его основные функции. Естественно, государство также отражает классовый характер, а придание классовости однобокого внимания уже при зарождении плодит искалеченные литературные образы.

В 1954 году Ф. Хусни отмечает, что у главного героя повести А. Еники «Спасибо, товарищи!» («Рәхмәт, иптәшләр!», 1952) некоторые поступки Нургали не были мотивированы. В романе М. Амира «Люди из Ялантау» («Ялантау кешеләре») также прослеживается некоторая идеализация характеров Сании и Камиля. Это объясняется тем, что писатель находится в тесной связи с концепцией положительного героя.

1960-е годы - очень важный период в истории татарской прозы. В эти годы она достигла больших, достойных внимания успехов как по качеству, так 
и по количеству. Эти успехи и, более того, оживление прозы 1960-1980-х годов связаны с двумя основными моментами.

Во-первых, в эти годы писатели старшего поколения стали заметно активнее творить. Давно вынашиваемые в душе творческие планы, начали сбываться. Например, вышли в свет объемные произведения Фатиха Хусни, Ибрагима Гази, Атиллы Расих, Амирхана Еники, Ибрагима Салахова и других творцов. Во-вторых, пришедшие в 50-е годы в литературу молодые писатели, к 60-м годам становятся уже мастерами пера, с малых литературных форм переходят к более объемным.

Романы и повести Рафаэля Тухфатуллина, Гарифа Ахунова, Нурихана Фаттаха, Аяза Гилязова, Мухамата Магдиева и других писателей стали известными широкому кругу читателей, и не только подхлестнули развитие татарской литературы, а возможно, что исследовав различные аспекты концепции личности в татарской литературе и подняв принципиальные проблемы, сделали важные исследования. Они в определенный период татарской советской литературы оказали влияние на создание различных вариантов положительных и иных персонажей и формирование эстетических принципов. Итак, концепция героя - это не какой-то застывший образ, а возможно, что и категория ясного восприятия изменений времени, которая в разные годы излагается по-особенному.

В определенные периоды литературоведы обрабатывают те или иные концепции героев. Аспекты концепции завязаны литературными направлениями, творческими школами, взглядами критиков. Работа над концепцией героя была необходимой задачей и в дореволюционный период, и после революции. «Не ошибемся, если скажем, что концепция героя была одной из самых проработанных и изученных в советском литературоведении. Данная концепция нашла отражение в монографиях, диссертациях и многочисленных статьях. Татарская литература, будучи частью всеобщего 
литературного процесса, материалы для данной концепции обретала в основном из русской советской литературы», - пишет Р. Салихов [16, с. 3-5].

И в советской литературе в процессе эволюции концепции героя при определении особенностей для осознания и описания литературного героя наблюдаются различные блуждания, разность оценок даваемых человеку, равно как и откровенные ошибки. С развитием общества новая концепция литературного героя также переживает серьезный рост и изменения. Она обогащается новыми качествами и одновременно освобождается от некоторых односторонних взглядов.

В истории татарской литературы XX века в определении концепции героя преобладает социологический метод, возрастающий до вульгарного социологизма. В каждом периоде процесса развития литературы происходит обобщение опыта героя.

В то время, когда в обществе торжествует демократия, свобода слова, при изучении творчества того или иного писателя необходимо ставить перед собой концепцию человечности и своеобразие концепции личности. На первое место ставят человечное и милосердное отношение к ближниму, описание человеческого воплощения божественной силы, дитя природы. В этой плоскости в любой литературный период изучение проблем героев принимает свои, присущие ему особенности. В литературном герое отражается не только отношение к нему самого писателя, а также отношение общества того времени к личности, понимание человеком его роли в мире и обществе. В героях показываются моральные и этические нормы поведения, яснее сталкиваются философские воззрения. Образ героя дает понять и усвоить мир, играет роль в воспитании и душевном обогащении, показывает направляющие силы развития общества.

В литературе второй половины XX века, а именно 60-80-х годов, концепция героя обозначена как эпоха осознания татарским народом значения человеческого бытия. Когда в сложной плотной взаимосвязи с обстановкой 
рождаются герои определенного типа, концепция героя претворяется в жизнь посредством художественных приемов. А совместно с воззрениями самого автора находит еще более широкое отражение в рамках стиля произведения. В литературоведении художественная концепция героя становится центром сплочения всех элементов произведения. Значит, при изучении творчества того или иного писателя, при определении содержания политической и моральной стороны произведения, следует понять то, как писатель раскрывает проблему героя.

В различные периоды развития общества и литературы появляются множество разновидностей концепции литературного героя. Но организм литературы не желает воспринимать ни искусственные абстракции, ни идеологическое давление, она их отторгает. Эта борьба, как правило, затягивается и в период продолжительного развития литературы, концепции героев заменяют друг друга, рождают иллюзию борьбы за освоение территории литературы.

«Нужно отметить еще один важный момент: писатели все время ищут ответ на какой-либо вопрос и, сами того не замечая, выходят на запретную территорию. Сейчас уже общеизвестно, что царившая в литературе начала $\mathrm{XX}$ века идеология многого не разрешала. Даже раскрыт негласный список проблем, которых нельзя было касаться. Это уже совсем другая вселенная: мир воров, казнокрадов, больших и малых подлецов, прочих негодяев, то есть, совершенно иной, малоизвестный официальному миру, разрез общества. Конечно, о его существовании прекрасно знали, но не хватало смелости довести до непосредственного столкновения. Появление произведения, основанного на подобном материале, произвел бы шок, и стало бы для многих просто откровением. Это вызвало бы эффект непонимания. Не понимали обычно автора, имевшего самые благие намерения - оздоровить и исправить общество. Он казался очернителем советской действительности, так как в «идеальном» мире такого быть не должно, и совершенно не принимали в расчет 
то, что этот мир является оборотной стороной советской действительности, хотя бы потому, что формально подчиняется законам официального мира. Например, так было почти со всеми произведениями А. Еники, некоторыми вещами А. Гилязова, А. Баяна, Н. Фаттаха и других» [16, с. 7].

Но времена меняются, а вместе с ним меняются и взгляды на окружающий мир. Как пример этого, в 2004 году на страницах журнала «Огни Казани» («Казан утлары») вышла рубрика «Герой нашего времени», где среди прочих был задан вопрос: «Кто он герой нашего времени?», и на эту тему началась дискуссия. Это было организовано редактором по вопросам критики и библиографии Мансуром Вали-Баржылы. В статье «Кого ждет душа?» («Күңел кемне көтә?») он ставит такой вопрос: «Какой он, герой нашего времени, в реальной действительности последних годов? Кого мы ныне называем героем?» [2, с. 134]. И сам же проводит мысль, что герою присуще отвага, смелость, самоотверженность, преданность». Автор называет даже примеры имен героев нашего времени. «... говоря о смелости и отваге, в голове возникают образы благородных, храбрых парней, таких как Шакирзян Мухаметзянов и Газинур Гафиятуллин периода Великой Отечественной войны, Рифкат Миргазизов из армейской жизни 80-х годов», - пишет он [2, с. 135]. А Айдар Халим «героя нашего времени» характеризует следующим образом: «Как воспитать нравственно-героическую нацию, если геройство твоей нации ранее не совсем описывалось? Не описав божественность и веру, разве можно воспитать искренне убежденную нацию? При отсутствии сражающейся за свою нацию литературы, разве возможно воспитать борца нации? Творчество писателя начинается с его национальной трагедии. Мы - дети татарской трагедии. Имея свою литературу, наша трагедия все еще не описана. Не трагедия ли это двойне?» [19, с. 124-125].

Действительно, необходимо многосторонне подходить к вопросу героя в татарской литературе, имеющей тысячелетнюю историю. Только тогда мы убедимся и поймем, что «герои нашего времени» в прозе Разиля Валеева не 
сошли с небес, что данное понятие является в какой-то мере управляемым государственным процессом.

Конечно же, понятно, что невозможно создавать современные произведения исключительно для демонстрации героя нашего времени. Рафик Шарафиев откровенно пишет об этом, в породившей дискуссию статье «Придет ли? Увидим ли?» («Киләме, күрәбезме?»). На вопрос: «Кто пришел на место прежних «положительных героев»?» - автор отвечает таким образом: «всякий сброд, грабители, короли мафии, перешедшие черту распутства личности, развратные женщины и прочие, ошивающиеся около них несчастные... Неужели это действительно мы? Настолько испачкались мы с ног до головы, стали жестокими, бессердечными. Мы же теряем лицо свое» [20, с. 163]. Такие же процессы можно наблюдать в жизни и в образе существования таких героев прозведений Разиля Валеева, как Фаяз и Амина («Эт кояшы»); Искандер, Интизар, Рудэль, Мотигулла, Сагидулла, проводница поезда («Иске сәгать дөрес йөри»); Залия Тарханова, Нурислам Фарукшин, Урманов, Шамкаев («Мирас») и др.

Кроме того, Р. Валеев в своих произведениях изображает тех героев, которые раскрываются с неожиданной стороны. Этих героев он берет из реальной жизни. Характерные черты своих образов автор по отдельности находит в повседневности. При описании внешности героя он отталкивается от какого-либо реального человека. Как результат, образы обогащаются фантазией автора и, таким образом, превращаются в весьма естественных героев. О своих героях автор такого мнения: «Люди все разные. И близко не познав своего героя, при написании произведения невозможно сотворить какой-либо образ. Поэтому в каждом моем произведении образы имеют свои прототипы из жизни...» $[1$, с. 5].

В произведениях Р. Валеева разоблачается достаточно широко распространённая негативная практика воспитания и обучения в отрыве от реальной жизни и физического труда. Автор уделяет внимание раскрытию 
философско-поэтического значения труда, старается давать прочувствовать прелесть и наслаждение от работы на селе. Также отводит много места описанию любовных чувств и переживаний героев. Какого произведения ни коснись, в каждом подробно изучается и отражается внутренний мир человека. Видно, что в успехе произведения достаточно большую роль играет психологизм. Автор описывает своих героев с чувствительной, словно барометр душой. Его в первую очередь волнует поведение молодежи, которая делает свои первые шаги в большую жизнь: «Кем станут они? Какой путь выберут? Каковы будут их цели?». А ответы на эти вопросы он предлагает искать самому читателю, изображая судьбы Ихтияра-Залии (в романе «Мирас»), Ирека-Амины (в повести «Эт кояшы»), Искандера-Сюмбель (в повести «Иске сәгать дөрес йөри»), Рифката Миргазизова (в повести «Яшисе килә!»). С этой стороны автор использует шаг, достойный внимания: он во многих случаях не торопится давать готовые развязки, выводы. Принимать или не принимать тот или иной поступок героев он оставляет на усмотрение самого читателя. По ходу событий каждый раскрывает свою сущность, и к жизненным испытаниям каждый приходит со своим морально-нравственным багажом.

В процессе изображения внутреннего мира своих героев Р. Валеев касается щекотливых тем современности. Например, плачевное состояние сегодняшней деревни: безработица, пьянство, аморальный образ жизни, исчезновение деревни. В этом автор обвиняет бестолковых, неспособных руководителей. Но в то же время от такого одностороннего взгляда писатель весьма ловко уходить. Эти бросавшиеся в глаза причины автор воспроизводит из уст главных героев, Ихтияра, Нурислама, Фаяза, Амины, проводницу, Искандера.

Например, некоторые жители деревни в романе «Наследие» («Мирас»), устав от несправедливости в политике строительства, стали халатно относиться к работе и жизни. Опасно то, что находится основание для самооправдания подобного равнодушия: работаешь ли, не работаешь ли - результат один и тот 
же, говорят они. Путем размышлений и наблюдений автор находит героев, связанных своими корнями с работой на земле, и начинает описывать их. Например, в романе «Наследие» («Мирас») особенно ярко описываются два контрастных героя, занимающие противоположные позиции. С одной стороны, это философия жизни Ихтияра, а с другой - философия Тимерхана и Зыятдина. живущих по-старому.

Ихтияр видит смысл жизни не только в личном счастье, но и в полезном служении обществу и людям. В образе старика Зыятдин автор изображает личность, прошедшую огонь и воду. И, несмотря на возникающие трудности, эта личность никогда не сдается, «если вдруг упадет, то сразу поднимет голову», предстает перед глазами как светлый маяк. На примере старика Зыятдина писатель, не прибегая к чтению нотаций, показывает достойный пример современной молодежи, а на примере судеб героев своих произведений дает поучительные уроки о жизни и истории народа. Хотя произведения автора направлены на нравственное и трудовое воспитание молодежи, через действия героев произведения он незаметно призывает задумываться о дальнейшей судьбе нации.

Р. Валеев изображает сельскую жизнь, думает о будущем деревни. Да, татарская нация в основном сохранилась только в деревне, так будет и дальше. Защитником татарского языка тоже является деревня. Значит, автор, касаясь проблем татарской деревни, поднимает национальные проблемы. Нужно отметить, что сам автор тоже родился и вырос в деревне, получил там образование, воспитание, и поэтому он не равнодушен к этой несправедливости.

\section{Список литературы}

1. Валеев Р. Избранные произведения: романы и повести. - В 4 книгах. Казань: Национальная книга, 2000. - Книга II. - 496 с.

2. Вали-Барзылы М. душа кого ждет// Огни Казани.- 2004. - №6. - с. 134

3. Волков И. Теория литературы: Учебное пособие для студентов и преподавателей. - М.: Просвещение, Владос, 1995. - 256 с. 
4. Галиуллин Т. В завоевании новых высот: статьи литературной критики. - Казань: Татар. книгизд., 1972.- 151 С.

5. Гусманов М. По следу пера. - Казань: Татар. книгизд., 1994. - 407 С.

6. Гусманов М. В объятиях - пространство, в намерениях - искренность // Татарстан. - 2007. - № 68-69; - С. 5.

7. Гуковский Г.А. Изучение литературного произведения в школе: Методологические очерки о методике. - Тула: Автограф, 2000. - 224 с.

8. Гилязов Т. Татарская литература. Начало XX века. Лекции, практические занятия, тесты. - Казань: Изд-во «Просвещение»., 2007. - 157 С.

9. Словарь литературоведения / Сост. - ред. А.Г. Ахмадуллина. - Казань: Татар. книгизд., 1990. - 238 С.

10. Залялиева М.Ш. Истоки нашей литературы - Казань: Мэгариф, 2001. $128 \mathrm{C}$.

11. Загидуллина Д. На новой волне// Огни Казани. - 2003. - №7. - С. 152160.

12. Загидуллина Д.Ф. История литературы и современность - Казань: Татар. книгиздат., 2000. - С. 246-270.

13. Миннегулов Х.Ю. Татарская литература и Восточная классика. Казань: Изд-во КГУ, 1993 - 384 с.

14. Миннегулов Х. В мире есть слово... - Казань: Татар. книгизд., 1989. C. 35. (на татарском языке).

15. Нуруллин И.З. В мире образов: статьи литературной критики Казань: Татар. книгизд., 1964 г. -140 с. (на татарском языке).

16. Салихов Р.Г. Герой и эпоха (концепция героя в татарском литературоведении). - Казань: Мастер-Лайн, 1999. - 352 с.

17. Салихов Р.Г. Концепция героя в татарском литературоведении: спецкурс для студентов. - Елабуга: АДПИ, - 2001. - 72 с. (на татарском языке).

18. История татарской литературы: в шести томах. Татарская советская литература (1917-1941) / Н.Г. Юзиев, Н.Ш. Хисамов, Г.М. Халитов. - Казань: Татар. книгизд., 1989 г. - Т. 4. - 568 с. (на татарском языке).

19. Халим А. Кто такой «Герой современности?» // Огни Казани.- 2005. - 
№1. - С. 124-125. (на татарском языке).

20. Шарафиев Р. Хотите, увидите? // Огни Казани. - 2004 г. - №1. С. 163. (на татарском языке)

(C) А.С. Хайруллина, 2021 


\section{ГЛАВА VI.}

УДК 821.111(73)

ОСОБЕННОСТИ ИСПОЛЬЗОВАНИЯ ЛИТЕРАТУРНЫХ ЭЛЕМЕНТОВ

В КИБЕРТЕКСТАХ: ПРИСПОСОБЛЕНИЕ ЛИТЕРАТУРЫ

К ИНТЕРАКТИВНОЙ СРЕДЕ

Конникова Виктория Николаевна

Белорусский государственный университет

Аннотация: в данной работе автор стремится проанализировать, каковы специфические пути трансформации литературы и её адаптации к интерактивности в пределах кибертекстов; сравняются пути, которыми аналогичные элементы представлены в неэргодической художественной литературе и в кибертекстах; делается общий вывод касательно существования литературы в интерактивных средах.

Ключевые слова: эргодическая литература; неэргодическая литература; кибертекст; интерактивность; собственно литературные элементы кибертекста; трансформация литературы.

\section{SPECIFICS OF LITERATURE ELEMENTS' USAGE IN CYBERTEXTS: ADAPTATION OF LITERATURE TO THE INTERACTIVE ENVIRONMENT}

\section{Konnikova Viktoria Nikolayevna}

Abstract: in this work the author strives to analyze, what are the specific ways in which literature transforms and adapts to interactivity within cybertexts; the ways, 
in which the same phenomena are represented in non-ergodic works of fiction as opposed to cybertexts, are compared; the general conclusion considering the existence of literature in interactive environments is drawn.

Key words: ergodic literature; non-ergodic literature; cybertext; interactivity; specifically literary components of cybertexts; transformation of literature.

В современном стремительно меняющемся мире сложно ожидать, что восприятие значения слова «литература» останется неизменным, или что существует только одно, общее для всех. Напротив, и само слово, и люди, его использующие, разнятся в мнениях на то, что включается в это понятие.

«Littěra», в переводе с латыни, означает «буква», во множественном числе слово может означать «буквы, письмена, письмо» [1, с. 355]. Суффикс «-tūra» придаёт слову, образованному с его помощью, значение действия или результата этого действия $[1$, c. 130]. Исходя из их комбинации, дословным переводом слова «литература» будет «написанное». Таким образом, оригинальное понятие литературы можно трактовать как всё, что было записано человеком. Близко к нему и понятие из словаря Ушакова: «Вся совокупность письменных и печатных произведений того или другого народа, эпохи или всего человечества в целом; письменность, в отличие от устной словесности» [2, с. 274].

Иные понятия добавили в определение наличие намерения как то, что отличает литературу от нелитературных записей - и уже по намерению литературу разделяют на художественную, научную, техническую, и т.д. Например, подобное определение можно найти в словаре Ожегова.

В некоторых контекстах понимание ещё более сужается: наиболее часто, говоря о литературе, мы подразумеваем какой-то определённый вид. Чаще всего это художественная литература. Но, например, когда профессор говорит студентам ознакомиться со списком литературы для курса, здесь имеется в виду 
определённый набор текстов, связанных с содержанием программы занятий по этому курсу.

Это требует уточнения, что в контексте данной работы, говоря «литература», автор подразумевает именно художественную литературу, «fiction», кроме случаев, когда иной вид указан напрямую, а «литература в целом» относится к совокупности всех письменных произведений без временных и национальных ограничений.

Художественная литература, в свою очередь, определяется как вид литературы в целом, «изображающий реальность в образах» и «отвечающий требованиям искусства» [2, с. 743]. Это вид искусства, представленный письменно и в словесной форме.

Вид представления письма видоизменялся, от рукописи до печати, а затем до текста на экране. Текст, который предоставляется нам кибернетическими (компьютерными) методами - можно ли считать его кибертекстом?

Нет, согласно создателю термина - Эспену Аарсету. Текст, для ознакомления с которым читатель не совершает иных усилий, кроме как традиционного перелистывания страниц (или, в случае с электронными носителями, пролистывания текста на экране) и движения глаз, нельзя назвать кибертекстом [3, с. 1]. В его определении, это гораздо более специфическое явление, относящееся к эргодической литературе: литературе, требующей от читателя «нетривиального усилия» для ознакомления. Кибертекст - это в первую очередь текст эргодической литературы, способ представления которого читателю определён использованием кибернетических (компьютерных) средств. Для иллюстрации того, что конкретно это означает, можно привести пример, что Аарсет включал в понятие кибертекстов гипертексты (в компьютерном понимании) и видеоигры [3, с. 18].

Эргодическая сущность и в тех, и в других проявляется через интерактивность - возможность читателя/игрока взаимодействовать с кибертекстом и/или влиять на него. Так, в компьютерном гипертексте читатель 
формирует собственный процесс чтения, переходя по ссылкам. Примером этого может служить часто встречающаяся шутка о том, что зайдя на Википедию для того, чтоб уточнить что-то об одном явлении, пользователь спустя часы обнаруживает себя на странице, не относящейся к изначальной. В этом, однако, состоит сложность с рассмотрением гипертекстов подобной сложности и наполненности: мы имеем дело с очень большим количеством страниц, каждая из которых содержит ссылки на другую страницу. Переходя от странице к странице по ссылкам, которые его наиболее заинтересовали, пользователь редко может предугадать или повторить в точности весь процесс, разворачивающийся за часы взаимодействия с вебсайтом. Гипертексту в этом смысле свойствен элемент случайности, который возникает уже после нескольких первых переходов по ссылкам: что пользователь увидит? Что привлечёт его интерес? На что он кликнет? Что произойдёт на следующей странице? Подобная неспособность предугадать, что случится после нескольких последовательных переходов по гиперссылкам, означает, помимо прочего, что возможность компьютерного гипертекста порождать нарратив ограничена [4]. Мари-Лор Райан в статье, посвящённой описанию типов интерактивности, отнесла гипертексты к «внешнему исследовательскому» («external exploratory»): пользователь свободно перемещается по некой базе данных, но не имеет возможности повлиять на существующие элементы. Это легко заметить в гипертекстах: читатель имеет доступ ко всем текстам, размещённым в сети Интернет и связанным гиперссылками, но находясь в роли пользователя, он не способен повлиять на содержание веб-страниц. Содержание, с которым ознакомится читатель, и литературность этого содержания, зависят от того, через какие страницы он пройдёт. В совокупности, это означает, что гипертексты и процесс взаимодействия с ними настолько разнообразны и сформированы таким множеством факторов, что попытки проанализировать их выходят за пределы фокуса данной работы и заходят на территорию исследования содержания интернет-контента, психологии 
пользователей сети Интернет и того, как разные люди взаимодействуют с интернет-контентом.

В связи с этим, автор сосредоточил внимание на исследовании одной из иных разновидностей кибертекстов: видеоигр. Данный популярный вид мультимедийных развлечений прошёл долгий путь развития: от времён, когда для создания одной игры полностью перепрограммировался колоссальный компьютер, до появления распространяемых игр, до возникновения коммерческих и коммерчески успешных видеоигр и их последующего превращения в мультимиллиардную отрасль компьютерной индустрии.

Здесь необходимо слелать уточнение: говоря «видеоигры», автор включает в понятие все разновидности развлекательных программ, требующих наличия компьютерной платы для их функционирования, независимо от того, насколько в них представлена видео-составляющая. Термин «компьютерные игры» описывает суть феномена намного очевиднее, но при его использовании часто можно столкнуться с тем, что он ассоциируется у людей с играми только для персональных компьютеров. Термин «видеоигры» используется намного чаще в англоязычной литературе, и включает игры, созданные для любых платформ (игры для ПК, мобильные, консольные). Автор упоминает данный момент из-за того, что некоторые игры, исторически значимые для развития явления как такового, использовали текстовый вывод, а не изображения на дисплее.

Интерактивность - один из краеугольных камней современных видеоигр. Действия игрока формируют его приключение в игровом мире, определяют победу и поражение - и многое другое, в зависимости от того, какие возможности предоставляются игроку. Легко воспринять игры как отдельный вид искусства, существующий обособленно от литературы, - однако за каждым выбором, предоставленным игроку, стоит не только разработчик программной части игры, но и писатель. В играх, созданных маленькими командами или одним человеком, - как в случае ранних игр, создаваемых часто студентами 
или сотрудниками технических вузов, или современных «инди» игр, - обе функции могут приходиться на одного человека. Однако стоит помнить, что они несут в себе разное наполнение: задача писателя - продумать систему выборов и как они влияют на конечный результат, задача программиста обеспечить техническое воплощение идеи писателя. При этом, в отличие от неэргодической литературы, только часть литературного творчества в видеоиграх остаётся «на поверхности», в то время как другая становится менее явной в силу использования аудиовизуальных средств.

Соотношение «явных» и «неявных» литературных элементов в играх можно представить себе как спектр, представленный в крайней «явной» форме как исключительно текстовая игра, а на противоположной стороне - что можно обозначить как синематографическая игра без эксплицитно текстовых элементов.

Как пример исключительно текстовой игры можно назвать «Colossal Cave Adventure» (приблизительно 1975-1976, Уильям Кроутер). В данный период компьютеры не обладали возможностями, необходимыми для отрисовки графики, и ещё стоили настолько дорого, что для экономии некоторые не были оснащены мониторами и использовали телетайп как способ вывода. Игра совмещала два интереса своего создателя: спелеологию и «Dungeons and Dragons». Все локации, предметы и действия описывались словесно, взаимодействие с ними осуществлялось посредством печатного ввода команд из 1-2 слов [5]. Будучи целиком и в явном виде представленными как текст, игры из данной категории наиболее очевидно демонстрируют, как взаимодействие с миром игры посредством ввода команд формирует уникальный от игрока к игроку опыт взаимодействия, а значит и уникальный текст и нарратив в нём.

Говоря о синематографических играх, автор подразумевает подход, похожий к таковому при создании фильма: в кино от зрителя не ожидается, что он будет читать что-то, что промелькнуло на экране, а наилучший сценарий 
кинофильма - тот, который «в моменте» ощущается настолько органичным, что зритель не оказывается «выдернут» из повествования недоумением касательно того или иного действия или реплики персонажа. Но как над фильмами, так и над синематографическими играми порой работают команды писателейсценаристов из нескольких человек. В качестве успешного примера подобной игры часто называют «God of War» (2018), получившую высокую оценку не только за графическую составляющую, но и за проработанный сюжет и изображение развития отношений между главным героем и его сыном [6].

Если игры из текстовой части спектра легче проанализировать с точки зрения воздействия специфики медиума на их литературные элементы в связи с «обнажённостью» текста, то для остальных часто требуется привлекать иные приёмы. Часто это означает необходимость сперва определить предмет поиска: что считать литературными компонентами?

Автор данной работы в процессе исследования выделил следующие литературные компоненты в играх: сюжет, диалог, «журнал», «внутриигровые книги» и «глоссарий». Как можно заметить, только два из них совпадают с возможным наполнением художественного произведения неэргодической природы, остальным названия были даны автором, исходя из визуального представления в игре и выполняемой функции.

Сюжет в неэргодическом литературном произведении состоит из последовательности событий, которые складываются в завязку, развитие, кульминацию и развязку. Одно произведение может содержать несколько сюжетных линий, повествование может излагаться вне хронологического порядка, но к концу книги или серии книг читатель может соединить все точки в линию (или несколько линий). Однако сюжет не может быть изменён читателем внутри самого текста - фанаты того или иного произведения, в случае несогласия со мнением автора, могут «изменить»его только через создание отдельного элемента фанатского творчества. 
В игре подход к сюжету зависит от авторского коллектива, но обычно даже в случае с более линейным нарративом игроку даётся возможность почувствовать, что именно от него зависит исход игры. Например, часто более линейный сюжет свойствен экшн-играм: игровому жанру, который определяется необходимостью для игрока быстро реагировать на события на экране. Обычно жанру характерно наличие периодов боя - и через победы в них, собственный выбор оружия и тактики игрок ощущает собственное влияние на мир игры. Иногда в экшн-игры добавляются и иные интерактивные моменты, например, «quick time events» (дословно - «быстрые события на время», игроку необходимо нажать определённую кнопку до того, как истечёт время, для успешного совершения какого-либо действия игровым персонажем). Совместно, интерактивность боя и этих иных моментов позволяют создать у игрока ощущение если не влияния, то сопричастности.

Однако помимо игр с линейным сюжетом, существуют и те, где попытка визуально представить все возможные связи между выбором игрока и фрагментами сюжета рисует образ ветвей дерева, паутины или даже грибного мицелия. Игроку предоставляется выбор для решения как относительно небольших элементов сюжета, так порой и для гораздо более глобальных, влияющих на исход всей игры. Через последовательность сделанных выборов, в силу наличия нескольких возможных вариантов в каждом моменте выбора, количества этих моментов выбора, и возможности существования зависимости от предыдущих, можно создать количество уникальных сюжетов, стремящихся к бесконечности. Именно эта особенность - возможно, как наиболее отличающаяся от неэргодической литературы - упоминается чаще всего применительно к видеоиграм.

В качестве одного из примеров игры, где существует большое количество возможностей выбора, можно назвать Fallout: New Vegas [7]. Игрок выбирает, что делать или не делать, каким образом, и в который момент. И его действия имеют последствия: игра завершается слайд-шоу с рассказом о том, как его 
действия сказались на мире игры и в некоторых случаях, каковы были последствия спустя некоторое время. Выбирая пути завершения заданий, и какие именно задания выполнять, игрок может получить разные наборы финальных слайдов при разных прохождениях игры.

Подводя итог, сюжет в видеоиграх может быть как линейным, так и нелинейным. В случае нелинейного сюжета, интерактивность выступает средством прямого воздействия игрока на сюжет. В играх с линейным сюжетом, интерактивность сосредоточена в иных аспектах и направлена на обеспечение ощущения вовлечённости игрока.

Переходя к диалогу, необходимо отметить, что хотя большинство современных игр, выпускаемых большими студиями, используют актёров для полного озвучивания диалогов, сейчас, как и ранее, ещё встречаются игры с текстовым представлением диалога. Первый вариант - полностью озвученный диалог - можно снова сравнить с диалогами в кинофильмах: игрок может слышать голос персонажей и их интонации, понимать их отношение к происходящему и их эмоциональное и физическое состояние через голос. Интерактивность может как присутствовать, так и отсутствовать в подобных диалогах - или в пределах одной игры могут сосуществовать оба подхода. Присутствие интерактивности может быть достигнуто через наличие «колеса диалогов» (элемент интерфейса в процессе диалога, которые только вкратце даёт понять, что персонаж игрока скажет) или через меню с более развёрнутыми опциями, где игрок может прочитать всю реплику. Неинтерактивные озвученные диалоги обычно характеризуются большей синематичностью разговора: игрок наблюдает, как персонажи взаимодействуют, и возможно, достигает лучшего их понимания. В случае с текстовыми диалогами, реплики как персонажа игрока, так и его собеседников обычно представлены как развёрнутые предложения. В связи с тем, что нет необходимости нанимать актёров и убеждаться, что текст может быть прочитан вслух наиболее легко и быстро, текстовые диалоги могут содержать гораздо 
больше информации. Игрок всё так же способен взаимодействовать с диалогом через выбор опций, но в полностью текстовых диалогах его реплики намного чаще представлены в полной форме.

Иным интересным элементом, который можно заметить в ряде ролевых игр (в том числе Fallout: New Vegas, The Elder Scrolls V: Skyrim [8]), являются проверки на навыки. В первой из названных игр, они работают напрямую и явно: игрок видит доступные реплики, отмеченные как требующие определённого уровня определённого навыка. Если уровень навыка у персонажа игрока соответствует требуемому, выбор реплики даёт успех, если же нет - попытка убеждения или демонстрации навыка проваливается. При этом текст в реплике для удовлетворительного уровня навыка звучит всегда гораздо более компетентно, чем при неудовлетворительном уровне. В The Elder Scrolls V: Skyrim проверки навыков присутствуют в случаях, когда игрок пытается добиться чего-то от персонажей через убеждение, угрозы и взятки. Убеждение зависит только от навыка Красноречия, но для успеха угрозы также учитывается разница в уровне игрока и другого персонажа, а успех взятки зависит в большей мере от удачи. Сам элемент проверки навыка происходит из Dungeons \& Dragons, где для совершения действия игроки бросают одну из игровых костей, и результат действия зависит от результата броска и уровня физического атрибута или навыка, соответствующего действию.

Связь диалога с сюжетом также является важным элементом, как для неэргодических произведений, так и для видеоигр. Однако между этими двумя группами присутствует некоторая функциональная разница. Сюжет в неэргодических произведениях формируется действиями, которые могут быть обусловлены диалогом: например, персонаж А убеждает персонажа Б совершить некое действие. В диалоге могут выражаться намерения персонажей совершить действие. Диалог может служить методом введения сюжетной линии через рассказ о событии, происшедшем ранее. Он выполняет функции продвижения сюжета и создания конфликта. Но в связи с линейностью и 
предопределённостью неэргодического повествования автором, диалог не является собственно действием, чаще представая как мотив или катализатор. В случае видеоигр, часто выбор той или иной реплики в диалоге оказывает прямое воздействие на сюжет. Например, через выбор реплики игрок может также выбирать определённую сюжетную линию и отрезать возможность развития всех остальных. Это, в первую очередь, вызвано интерактивной природой игр: диалог является одним из способов прямого взаимодействия с миром игры. Здесь выбор того или иного развития диалога является синонимичным с выбором действия, продвигующего сюжет.

Таким образом, как и в неэргодических произведениях, диалог в видеоиграх служит целям характеризации персонажей, передачи информации, создания конфликта и продвижения сюжета - но интерактивность и присутствие возможности выбора означают, что в последних двух функциях игрок оказывает прямое воздействие на мир игры. Совершая выбор в диалоге, игрок также совершает действие, продвигающее сюжет. Помимо этого, в играх, где диалог озвучен, игрок напрямую слышит тон голоса и акцент персонажа, в то время как в неэргодической литературе автору приходится подбирать слова для описания тона и менять написание слов в диалоге для демонстрации акцентов или дефектов речи.

В переходе к собственно игровым литературным элементам и их лучшем понимании нам может помочь обращение к тому, как описания трансформируются в интерактивной среде. Разумеется, для игр, существующих только в текстовом формате, способ описания не отличается от любого литературного текста. Графические новеллы как жанр видеоигр, помимо текстовых описаний, также используют фоновый рисунок для представления локаций, где персонажи находятся, и рисунки персонажей, говорящих в данный момент, - часто в подобных играх для каждого персонажа существует набор таких рисунков, где персонаж демонстрирует ту или иную эмоцию. Таким образом, даже игры с преобладанием текста как способа представления могут 
прибегать к визуальным средствам для представления локаций и персонажей. Что же можно сказать об играх, которые расположены дальше на спектре от текстовых до синематографических, и как описание в них сравнимо с неэргодической литературой?

Здесь удобно рассмотреть различие на примере игр серии The Elder Scrolls и романов-новелизаций, события которых происходят в хронологический промежуток между событиями 4-й и 5-й игр. Таким образом, они пусть не описывают напрямую точно то, с чем сталкивается игрок вышеназванных частей, но дают возможность сравнить подходы к описанию уникальных для этой фантастической вселенной реалий.

Прежде всего, здесь необходимо упомянуть роль словесных портретов, пейзажей и иных значимых описательных фрагментов в фантастических произведениях в более традиционной книжной форме. Несмотря на то, что книги могут быть снабжены иллюстрациями, описание через эпитеты, сравнения и уподобления всё равно изначально передаётся через текст - даже авторам иллюстраций, если таковые не сделаны самим автором. Всё, что окружает персонажа и достаточно значимо для него, для повестования или для автора, получает своего рода словесное воплощение, которое позволяет читателю представить себе в общих чертах как выглядит тот или иной герой, объект или пейзаж. Однако успешное описание чего-либо в литературном произведении часто означает, что автору необходимо выбрать, что именно описать для гармоничного течения повествования, а также использовать «потайные ходы» метафор и уподоблений для более сжатого, но вместе с тем более понятного читателю повествования. Например: «If shore it could be called - it was actually a nearly impenetrable wall of mangroves, crouched in the water like thousands of giant spiders with their legs interlocked» («Если это можно было назвать берегом - это на самом деле была почти непроницаемая стена мангровых зарослей, скрючившихся в воде как тысячи гигантских пауков, nереплётиих ноги») [9, с. 41]. Данный отрывок создаёт в воображении читателя 
очень детальную картину густых зарослей - настолько густых, что они кажутся берегом, но вместе с тем очевидно состоящих из отдельных корней, которые вдобавок можно интерпретировать как угрожающие и ужасающие, что вызванно использованием образа тысяч гигантских пауков. Сравнение чего-то со стеной часто используется для передачи ощущения или надёжности и защищённости, или холодной недружелюбной неприступности - и в данном случае использовано второе значение. В контексте ситуации, когда двое из главных героев «Адского города» впервые оказались на неизвестной, непредсказуемой и предположительно враждебной территории, этот момент использован в полной мере для создания ощущения опасности.

В данном аспекте, синематографические видеоигры обладают преимуществом: если некое явление, персонаж, объект, феномен или местность появляется здесь, чаще всего это осуществляется не словесными методами. Игроку предоставляется возможность видеть, слышать и взаимодействовать с миром вокруг, пусть и ограниченная техническими особенностями игры. Новое для игрока понятие часто сопровождается немедленной демонстрацией того, что оно означает. Для создания того или иного впечатления часто используется не только визуальное представление, но и звук. Может показаться, что благодаря этому в игре не нужны словесные описания - но подобное заявление будет противоречить реальности. Словесные описания всё ещё существуют в играх - они могут только играть иную роль. Вместо того, чтоб быть единственным способом получения знания о героях, объектах и мире, словесное описание становится одним из. Например, в случае со сложными детально описанными мирами наподобие того, где развивается действие Тhe Elder Scrolls, всегда помимо присутствующих в игре элементов есть и иные, о которых игрок узнаёт из текстов или из диалогов с персонажами. В данной серии присутствует такое явление, как «внутриигровые книги» - текстовые фрагменты, не связанные напрямую с нарративом, вовлекающим игрока. Часто они играют роль создания видимости большей «обжитости» мира игры - 
присутствия в нём писателей, философов, учёных, собирателей фольклора, и т.д., не говоря уже о наличии в этом мире мифов и легенд, художественных и научных произведений, дневников, переписок между персонажами. В данном случае существование словесных описаний не может быть заменено - и существует параллельно - аудиовизуальным средствам представления элементов мира. Игроку обычно нужно совершить отдельное действие для того, чтобы прочитать внутриигровую книгу, что делает её объектом, существующим в пределах мира игры, но её содержание таким образом обретает дополнительный барьер от «основного» содержания игры. Это позволяет включить столько внутриигровых книг и описаний внутри них, сколько необходимо: благодаря тому, что прочтение данных книг является полностью добровольным осознанным действием со стороны игрока, заинтересованного узнать больше, автору нет нужды беспокоиться о нарушении течения повествования, которое развёрнутые описания могут привнести в более традиционную книгу.

Иные два подхода требуют сосуществования и словесного описания, и визуального (или аудиовизуального, или интерактивного) представления. В первом случае, они совпадают: словесное описание персонажа, объекта и т.д. представляется игроку до или после столкновения с ним. Например, во многих заданиях игрока просят найти тот или иной предмет и дают описание того, что именно нужно найти. Описание после столкновения может быть дано с расширенным, по сравнению с воспринимаемым игроком, количеством деталей, контекстом или предысторией: например, в The Elder Scrolls V: Skyrim [8] член Гильдии Воров, которому игрок может принести редкие находки, часто дополнительно описывает тот или иной предмет. То же самое можно заметить и в дополнении к The Elder Scrolls IV: Oblivion [10] - Shivering Isles, если приносить редкие и интересные находки в Кунсткамеру, а затем заказывать экскурсию по экспозиции. Порой описание того или иного персонажа, явления и т.д. появляется в «журнале» до или после встречи или 
взаимодействия: например, в процессе выполнения одного из заданий в The Elder Scrolls IV: Oblivion [10] игрок получает в журнальной записи описание призрака Одинокого Дозорного до того, как впервые видит его сам. Во втором случае, в The Elder Scrolls III: Morrowind [11] после встречи с высокомерной паломницей, требующей помощи от игрока, в журнале появляется запись, описывающая характер встреченной особы.

Случаи, когда данное словесное описание не соответствует действительности, часто заставляют игрока задуматься и в определённом роде провести собственное расследование: что случилось, что могло изменить реальность мира игры по сравнению с ранее полученным описанием, или каковы были намерения персонажа, давшего неверное описание. Например, в The Elder Scrolls V: Skyrim [8] глава Гильдии Воров намеренно делится с игроком неверным описанием характера и стремлений своей бывшей соратницы, чтобы настроить его против неё. Но после его предательства и встречи с ней, игрок получает полную реальную картину происходящего, которая противоречит всему, что игрок знал ранее.

Через данные примеры мы подошли к определению второго из специфических литературных компонентов внутри видеоигр: «журнала». Название этому элементу было дано по функциям и визуальному оформлению в игре: данный литературный компонент часто имитирует оформление полевого журнала, и содержит запись заданий, порученных игроку. Записи могут быть организованы по выполненным, активным и неактивным заданиям, могут быть неизменными или дополняемыми по мере выполнения заданий. Основной функцией журнала является сохранение и упорядочение информации о заданиях - но вместе с тем в некоторых случаях, особенно в случае ведения журнала от первого лица, он может помочь характеризовать игрового персонажа.

Пятым и финальным литературным компонентом в видеоиграх можно назвать «глоссарий»: как глоссарий к научной работе, он содержит 
информацию, объясняющую элементы игрового мира. Эта информация может предоставляться о персонажах, предметах, противниках, культуре мира внутри игры. В самих играх нет единого подхода к названию и оформлению глоссария: он может называться бестиарием, кодексом, и др., информация может быть предоставлена по выбору картинки, слова или карточки. Но независимо от различий, глоссарий выполняет одинаковые функции сохранения полезных фактов, которые могут помочь игроку запомнить, как лучше бороться с тем или иным противником, каковы культурные нормы для того или иного сообщества, а также что ему известно о собственных союзниках. Хорошим примером может послужить кодекс из серии игр Dragon Age. Равноправно упрощённым глоссарием или элементом журнала можно считать категорию «Темы» («Topics») в The Elder Scrolls III: Morrowind [11], где игрок может просмотреть ответы разных персонажей на темы диалогов.

Конечно, не каждая игра содержит все пять компонентов. Глоссарий, например, относится к наиболее редко встречающимся, и некоторые игры обходятся без диалога. Внутриигровые книги также встречаются намного реже, чем, скажем, журнал. В определённом смысле можно даже сказать, что сложный сюжет со множеством заданий, формирующих его, напрямую связаны с необходимостью журнала для их отслеживания.

Современные видеоигры как явление, сочетающее в себе элементы нескольких видов искусств (литература, изобразительное искусство, музыка только три наиболее очевидных), интересны и уникальны своей способностью к трансформированию данных видов искусства для достижения наибольшего воздействия на игрока. При восприятии видеоигр как кибертекстов основной фокус, конечно, приходится на литературную составляющую - но сложно переоценить значимость иных элементов для создания видеоигры как цельного интерактивного экспириенса: для игрока, который открывает её, все элементы в своём взаимодействии создают уникальный мир, который в случае успеха заставляет игрока вернуться не раз. 
Однако говоря о том, как интерактивность влияет на литературные компоненты кибертекстов, можно, прежде всего, сделать вывод, что взамен свойственной неэргодическим произведениям линейности, произведения кибертекста намного чаще представляют читателю/игроку возможность выбрать собственный путь, ограниченный только количеством запрограммированных опций. В связи с интерактивным характером мира видеоигр как разновидности кибертекста, игроку предоставляется возможность напрямую воздействовать на течение диалога и на сюжет. Благодаря активной позиции игрока, взаимодействующего с миром игры, создатели игр могут включить гораздо больше элементов экспозиции через использование внутриигровах книг и глоссария, в то время как автору книги приходится урезать и раскидывать по книге информацию мира игры для сохранения определённого ритма и избежания потери читательского внимания. Журнал служит аггрегации и иногда организации записей о заданиях, выполняемых игроком.

Рассмотрение интерактивности в кибертекстах указывает на то, что взаимодействие с ними и влияние на них читателя/игрока нисколько не умаляет значения литературных компонентов в них, но скорее ведёт к их преобразованию и появлению новых уникальных и специфических форм существования литературы.

\section{Список литературы}

1. Латинский язык. Учебник для факультетов иностранных языков педагогических институтов. Под общ. ред. В.Н. Ярхо и В.И Лободы. - 1969. М : Издательство «Просвещение». - 384 С.

2 Ушаков Д.Н. Толковый словарь современного русского языка. - 2014. М.: «Аделант». $-800 \mathrm{C}$.

3. Aarseth E.J. Cybertext. Perspectives on Ergodic Literature. - 1997. London : The Johns Hopkins University Press. - 202 P. 
4. Ryan M.-L. Beyond Myth and Metaphor - The Case of Narrative in Digital Media // Game Studies [Electronic resource]. - 2001.

5. Jerz D.G. Somewhere Nearby is Colossal Cave: Examining Will Crowther's Original "Adventure" in Code and in Kentucky // digital humanities quarterly [Electronic resource]. - 2007. - Volume 1 Number 2.

6. Dornbush J. God of War Review // IGN [Electronic resource]. - 2018.

7. Avellone C., Fenstermaker E., Gonzalez J.R., Hooper A., Newland S., Sawyer J.E., Scharf A., Stout T. Fallout: New Vegas. - 2010. - Rockville, MD : Bethesda Softworks.

8. Chapin B., Daniels M., Duvall J.P., Ellis N., Liesegang S., Nanes A., Pagliarulo E., Shen W. The Elder Scrolls V: Skyrim. - 2011. - Rockville, MD : Bethesda Softworks.

9. Keyes G. The Infernal City. An Elder Scrolls Novel. - 2009. - New York, NY : Del Rey Books. - 288 P.

10. Chapin B., Kirkbride M., Kuhlmann K., Nanes A., Nelson M., Nesmith B., Pagliarulo E., Peterson T. The Elder Scrolls IV: Oblivion. - 2006. - Rockville, MD: Bethesda Softworks/2K Games.

11. Burcham B., Goodall D., Howard T., Kirkbride M., Nelson M., Peterson P., Vaughn T. The Elder Scrolls III: Morrowind. - 2002. - Rockville, MD: Bethesda Softworks. 


\title{
Коллектив авторов:
}

Будаева Л.Н., Карамов Т.Д., Карамова А.А., Конникова В.Н., Потехина Е.С., Руденко Е.Е., Фесюкова И., Хайруллина А.С.

Редактор: Ивановская И.И.

НАУЧНОЕ ИЗДАНИЕ

\section{АКТУАЛЬНЫЕ ВОПРОСЫ И ВЕКТОРЫ РАЗВИТИЯ СОВРЕМЕННОЙ ФИЛОЛОГИИ}

\author{
Монография \\ Подписано в печать 20.09.21. \\ Тираж 500 экз. \\ Формат 60х84 1/16. Усл. печ. л. 8.37. \\ МЦНП «Новая наука» \\ 185002, г. Петрозаводск \\ ул. С. Ковалевской д.16Б помещ. 35. \\ office@sciencen.org
}




\section{НОВАЯ НАУКА \\ Международный центр научного партнерства

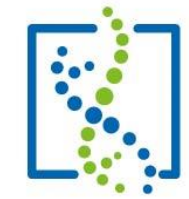 \\ NEW SCIENCE \\ International Center \\ for Scientific Partnership}

МЦНП «НОВАЯ НАУКА» - член Международной ассоциации издателей научной литературы «Publishers International Linking Association»

\section{ПРИГЛАШАЕМ К ПУБЛИКАЦИИ}

1. в сборниках статей Международных

и Всероссийских научно-практических конференций

https://www.sciencen.org/konferencii/grafik-konferencij/

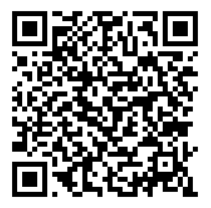

2. в сборниках статей Международных

и Всероссийских научно-исследовательских, профессионально-исследовательских конкурсов

https://www.sciencen.org/novaja-nauka-konkursy/ grafik-konkursov/

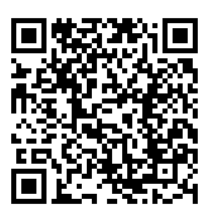

3. в составе коллективных монографий

https://www.sciencen.org/novaja-nauka-monografii// grafik-monografij/

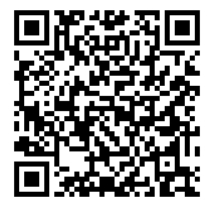

4. авторских изданий

(учебных пособий, учебников, методических рекомендаций, сборников статей, словарей, справочников, брошюр и т.п.)

https://www.sciencen.org/avtorskie-izdanija/apply/

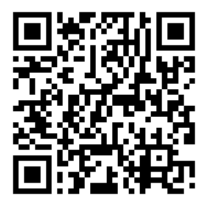

https://sciencen.org/ 